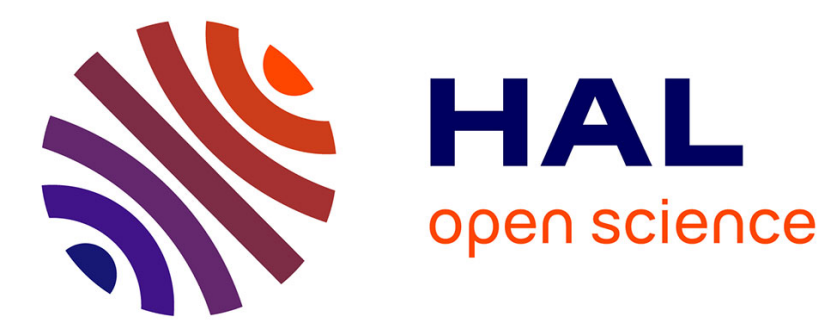

\title{
How fair are the fair price standards in blockholder regimes?
}

Adrian Pop, Diana Pop

\section{To cite this version:}

Adrian Pop, Diana Pop. How fair are the fair price standards in blockholder regimes?. 2014. hal01076722

\section{HAL Id: hal-01076722 \\ https://hal.science/hal-01076722}

Preprint submitted on 22 Oct 2014

HAL is a multi-disciplinary open access archive for the deposit and dissemination of scientific research documents, whether they are published or not. The documents may come from teaching and research institutions in France or abroad, or from public or private research centers.
L'archive ouverte pluridisciplinaire HAL, est destinée au dépôt et à la diffusion de documents scientifiques de niveau recherche, publiés ou non, émanant des établissements d'enseignement et de recherche français ou étrangers, des laboratoires publics ou privés. 


\title{
How fair are the fair price standards in blockholder regimes?
}

\author{
Adrian Pop* \\ Diana Pop**
}

\section{$2014 / 25$}

${ }^{*}$ ) LEMNA - Université de Nantes

$\left.{ }^{* *}\right)$ GRANEM - Université d'Angers

INSTITUT

d'ECONOMIE

et de MANAGEMENT

de NANTES - IAE

\section{Laboratoire d'Economie et de Management Nantes-Atlantique Université de Nantes \\ Chemin de la Censive du Tertre - BP 52231 \\ 44322 Nantes cedex 3 - France \\ www.univ-nantes.frliemn-iae/recherche \\ Tél. +33 (0)2 40141717 - Fax +33 (0)2 40141749}

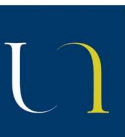

UNIVERSITÉ DE NANTES 


\title{
How fair are the fair price standards in blockholder regimes?
}

\author{
Adrian POP\# \\ University of Nantes (LEMNA) \\ Diana POP* \\ University of Angers (GRANEM)
}

First version: March 2014

This version: September 2014

\begin{abstract}
This paper examines the impact of frequent changes of investor protection regulation on the bid premium levels and the reception of the bid by the minority shareholders in blockholder regimes. In order to document the corporate governance function of takeover regulation, we explore a comprehensive data set representing more than $90 \%$ of the takeovers organized in Romania between 1998 and 2012. The peculiar institutional framework in Romania allows to factor in the analysis an hitherto unexplored structural element, namely the parallel control transactions managed by the Government, outside the stock market structures. After controlling for the influence of corporate governance and ownership attributes of targets, our main findings suggest that various market price components are strong predictors of both bid premiums and tender success. Besides, the alignment of legal details to the requirements of the European takeover regulation has a surprising negative effect on minority claimants. If the shareholders are indeed able to distil the pertinent information about a bid, our overall result suggests that the balance
\end{abstract}

\footnotetext{
\# University of Nantes (LEMNA), Chemin de la Censive du Tertre, BP 52231, 44322 Nantes Cedex 3, France. Tel.: +33-2-40141654; fax: +33-2-40141650. E-mail: adrian.pop@univ-nantes.fr

* University of Angers (GRANEM), 13 Allée François Mitterrand, BP 13633, 49036 Angers Cedex 01, France. Tel.: +33-2-41-96-21-24; fax: +33-2-41-96-21-96. E-mail: diana.pop@univ-angers.fr (corresponding author)

Acknowledgements

We are indebted to Azizjon Alimov, Paul Frentrop and participants at the $1^{\text {st }}$ Academic Conference of the International Corporate Governance Network, the $6^{\text {th }}$ International Conference of the International Finance and Banking Society and the 2014 Annual Conference of the Asian Finance Association for useful comments and suggestions; The Romanian Privatization Authority, The Romanian Financial Supervisory Commission, Tradeville, Romanian Universe for helping with data. A. Pop gratefully acknowledges financial support from the Chaire Finance of the University of Nantes Research Foundation. D. Pop gratefully acknowledges financial support from the Rules and Markets Chaire - GRANEM of the University of Angers.
} 
between competing concerns of protecting minority shareholders and facilitating value-creating transactions is still open to debate in emerging markets.

JEL Classification: G32, G34, G38

Keywords: takeover regulation, fair price standards, shareholder rights, corporate governance, privatization, takeover premium. 


\section{Introduction}

The law and finance literature pioneered by La Porta et al. (1998) claims that the distribution of corporate ownership emerges in response to the quality of legal protection of property rights. On this ground, the concentrated ownership is an endogenous mechanism that shelters the investor rights when the governance standards are poor. However, a two-decade retrospective on the experience of transition economies from CEE reveals that ownership of public companies could be concentrated by design, from the very first stage of privatization. Reforming governments of nineties assigned a major role in corporate restructuring to controlling strategic investors arguing the long term stance of their investment strategy and their enhanced ability to overcome investment problems in undercapitalized companies. However, irrespective of the endogenous or exogenous nature of blockholdings, the received wisdom is that minority shareholders can afford little against the value-reducing manoeuvers of controlling shareholder. Thus, limiting expropriation has become the primary concern of market authorities in charge with the development of the regulatory framework in genuine blockholder regimes.

Even if there is no infallible way to eliminate the extraction of private benefits of control in concentrated ownership, the interests of minority shareholders can be internalized ex-post in the event of a change in control over the company business. The pricing mechanism of corporate control transactions, given that acquirers make a bid for all outstanding shares of the offeree company at a non discriminatory price, assures that minority shareholders benefit of the premium paid for the controlling stake, which includes implicitly the portion of benefits used by the incumbent for its private advantage. Because the Mandatory Bid Rule (hereafter MBR) cancels any control premium and bans the partial offers for controlling blocks, minority shareholders are insulated from coercive bids by their binary tendering decision itself. Shareholder democracy in acquisitions renders the bidding price economically relevant when the offeror is able to force residual shareholders to sell their shares and gain full control in offeree company. Particularly, the European Takeover Directive prescribes that the considerations offered in a previous takeover bid that allowed the acquisitions of a stake providing the acquirer with a squeeze-out right are presumed to be fair. 
The effectiveness of the takeover regulation as corporate governance mechanism was taken for granted in all the European emerging markets. Under the pressure of legal harmonization, the equal opportunity rule and fairness concerns have been restated in the national market laws and the corporate governance codes of stock markets. One of the main conclusions of the Takeover Bids Directive Assessment Report prepared in 2012 for the European Commission shows that investors' community believes that MBR has a strong positive impact on the protection of minority shareholders in concentrated ownership. Nevertheless, Goergen et al. (2005) consider that benchmarking the value of squeeze-out right against the takeover price is likely to decrease the overall consideration and consequently the bidding premium. Besides, the academic contributions of Comment and Schwert (1995), Rossi and Volpin (2004), Anderson et al. (2009), Marshall and Anderson (2009), Alexandris et al. (2010), and Croci and Petmezas (2010) found that targets enjoying strong protection environments are able to extract higher takeover premiums than those facing poor governance standards. Such a new insight makes us conjecture that despite the harmonization of certain rules and regulatory convergence, the success of a recipe for an effective investor protection does not depend only on the dose of each ingredient but also on the sequence in which those ingredients are processed.

The Romanian market for corporate control is well suited to the assessment of the effectiveness of takeover regulation, in view of its main objectives, at least for two reasons. First, it allows to test whether the flexibility provided to the national financial authority to use some exceptions and derogations from the general principles affects the interests of minority shareholders. Even if the bid for a control position is mandatory from the very market inception, the national regulation exempts the offerors from this legal obligation in case of privatization of a listed company. The interference of Government in the chronology of control transactions concluded among private investors casts an entirely different light on some flagship legal measures leveling the playing field, like ownership transparency provisions ${ }^{1}$, mandatory bid rule and squeeze-out rule. The structure of the bids completed on the Romanian market for corporate control reveals that acquirers and controlling shareholders of targets have rarely been distinctive entities and that many of them previously bought the majority block directly from the Government, outside the

\footnotetext{
1 Information related to share and control structures are addresses mainly by the Transparency Directive (pre-bid general disclosure)
} 
market structures. Under such circumstances, the disclosure requirement of the ownership positions, even if triggered at the traditional levels of $5 \%$ or $10 \%$ of voting rights, looses practically its main functions as exclusionary mechanism, namely disseminating information about the likely targets and timing when the valuation of prospective bidders is revealed to the market ${ }^{2}$. Besides, the takeover law accommodates the Government's interest in the detriment of the other categories of shareholders. Thus, an investor who buys within privatization even a minority block that added to his previous holdings makes him exceed the controlling threshold may get around the MBR. Practically, the minority shareholders are not entitled to participate in any sale transaction involving Government holdings. Berglöf and Pajuste (2003) treat these peculiar block trades, suggestively called in the market law "excepted transactions", as a manifestation of poor governance in Romania. This way of securing control in public companies provided the dominant shareholders a large information advantage over external investors and an opportunity to exploit the inefficiencies caused by the low free float. Pop (2006) finds that minority shareholders cannot appropriate any fraction of the takeover surplus, especially when the target is already controlled by a major shareholder who previously traded a block with the privatization authority (hereafter AVAS). Sometimes those direct deals involved blocks providing more than $90 \%$ of voting rights, increasing thus the probability that a controlling shareholder would later take the company private often without performing any previous market transaction (Chemla et al., 2010). Second, the focus on the individual experience of the Romanian market helps quantifying not only the effects of takeover law but also the contribution of other legal provisions not necessarily covered by the Directive to the scope of minority shareholders protection during different periods of regulation. Atanasov et al. (2007) underline that interactions among legal provisions, on one hand, and among provisions and institutions, on the other hand, have different dilutive consequences on minority shareholders. Particularly, the frequent changes of legal details concerning the mandatory bid thresholds, the minimum bidding price condition, the benchmarks used for establishing delisting terms, the restrictions placed on acquirers' actions corroborated with anti-dilutive statutes and preemptive rights allow us endorsing the dynamics of legal design into the broader institutional framework of a country

\footnotetext{
${ }^{2}$ Once the market identifies the prospective bidders, they can no longer buy any share of the target at a price lower than the post-acquisition value of the share (Shleifer and Vishny, 1986).
} 
belonging to the legal family providing the weakest investor protection according to LLSV (1998).

In order to address this research question, we conduct an empirical analysis on the size of takeover premiums and bid outcomes, which covers the entire takeover contest involving the Romanian public companies between 1998 and 2012. In order to get a complete picture of the bidding process we include all the transactions approved by the Romanian Stock Exchange Commission (hereafter CNVM), whatever the initial ownership of acquirers. We explicitly take into account the importance of other alternative mechanisms allowing the offerors to lessen the burden of the mandatory bid requirement, like privatization deals or standard capital increases.

The privatization process is a key governance issue because it affects the dynamics of ownership and the organization of corporate structures. However, due to its very nature, such a dimension is country-specific and cannot be extrapolated to the international context. In Romania, despite an ample mass privatization program, ${ }^{3}$ which was followed by a broad representation of the partially privatized companies on the stock market, the selling process of Government's blocks had been carried out over more than twenty years. Those transactions, concluded outside the bounds of the stock exchange, have increased the availability of ownership per se making the appetite of novel riders and empire builders easier to satisfy. Besides the opportunity provided to investors to structure creeping acquisitions, and their obvious impact on the control contestability in the privatized companies, such parallel control transactions, in aggregate, could have had an in-play effect on the pricing of blockholdings. The prospective bidders, even if not involved in the competitive auctions or the direct negotiations organized by AVAS, observe the privatization outcome, which is public information. The privatization price plays a yardstick role in anchoring the value of control and thus affects the propensity of acquirers to overpay in M\&A when blocks in so many other companies are available. Consequently, this privatization price component should be observable in the takeover premium paid in acquisitions concluded under the scrutiny of the market. While privatization routinely delivers a basis for the control price, the size of

\footnotetext{
3 In 1995, the Romanian Government decided to transfer to citizens for free either $40 \%$ or $60 \%$ of the share capital in almost 6.000 companies. Nevertheless, at the end of the subscription period many of those blocks were only partially privatized and were included back into the Government portfolio.
} 
contemporaneous privatization premiums or discounts in other public companies should not affect the reception of the bid by the target shareholders and thus their tendering decision. To the best of our knowledge, there is no other previous study addressing the interactions between the pricing of those two complementary control transactions types.

Faccio and Stolin (2006), Atanasov et al. (2010) argue that the scope of expropriation has investment implications inducing an ex-ante pricing adjustment that depresses the value at which the minority stakes are bought in the first place. Thus, controller's opportunistic behavior is already factored into the valuation of public companies and the size of expected returns. A market pricing mechanism that already includes the information about prospective dilution alters the baseline for the tender offers, too. Under such circumstances, the compensation offered to minority shareholders would help preserving the allocational efficiency, unless the acquirer can reap a benefit by offering systematically lower takeover premiums. We check this question empirically by exploring a novel determinant of takeover premiums and tender success that control for effective dilution via equity changes. Even if from a legal perspective, capital increases with preferential subscription rights cannot be used to avoid the application of the $\mathrm{MBR}^{4}$, such strategies could influence the way the control is exercised in listed companies and consequently the propensity of minority shareholders to accept less favorable terms in a subsequent takeover bid. An obvious concern in this area is that financial tunneling is a perverse expropriation mechanism that precedes and facilitates freeze-outs.

As in Betton and Eckbo (2000) and Bates et al. (2006), we expect to learn about the bidding strategy from initial deal attributes, as well as from revised terms. Bid revisions give insights on the competition for the control rights by third-party bidders (Betton and Eckbo, 2000) or the balance of power between minority and major shareholders, especially in freeze-outs via tender offers (Bates et al., 2006). However, our contention is that the type of revision conveys different information about the exposure of minority shareholders to self-serving offers by bidders. After controlling for the rival bids, the bid jumps are consistent with greater bargaining power of minority shareholders who are able to extract from acquirers a larger portion of the deal surplus,

${ }^{4}$ In Romania, a controlling shareholder who is not willing to initiate a takeover bid must dispose of the shares exceeding the threshold triggering a MBR within 3 months (also applicable to mergers or divisions). 
even in the absence of explicit negotiations. On the contrary, extending the bid period without adjusting the bid price is likely to signal a conflict inherent to entrenched ownership structures. Remaining shareholders are unwilling to exit at the bidding price but in reality they cannot influence the structure of the offer.

This paper provides evidence on the pattern of open market transactions and block trades such as purchases, sales and net purchases, made by insiders with target shares before takeover announcement for a sub-sample of acquisitions announced between 2006 and 2012. Two competing, but not necessarily exclusive, hypotheses state that the price run-up in the target shares before acquisitions is driven both by the market that anticipates an impending takeover bid and insiders trading on private information about target. ${ }^{5}$ The acquirers and the persons acting in concert with them should have an interest in building short-term toeholds in the target (Betton et al, 2013; Aspris et al., 2014). The observed trades provide arbitrage opportunities to other institutional and individual investors who update the stand alone value of the target compelling bidders to offer higher initial bidding prices and affecting the deal outcome (Heish and Walkling, 2005). ${ }^{6}$ However, the strategy of purchasing short-term toeholds can be costly to the bidder by driving up the market price. The 52-week high price is a common reference across target shareholders (Suzuki and Kruse, 2010; Baker et al., 2012; Betton et al., 2013) that should have a considerable effect on the bidding price and the willingness of target shareholders to embrace the offer. According to the takeover law, if the historical highest price was actually paid by the acquirer, it becomes an explicit fair price benchmark and can be hardly used as an appeal to tendering. Such a benchmarking imposed by regulation could provide a novel explanation to the substitution effect between the runup and the markup, which is specific to regulated markets for corporate control. ${ }^{7}$

The reminder of the paper is structured as follows. Section 2 describes the data selection procedure while the section 3 presents the explanatory variables and testable hypothesis. The

\footnotetext{
${ }^{5}$ Jabbour et al. (2000), exploits such detailed information on the Canadian takeover market and found that insider trading intensifies during the two months preceding the acquisition doubling the abnormal returns observed on days with no insider trading.

${ }^{6}$ A comprehensive study on the gain of insiders on roundtrip trades and the enforcement mechanisms against this activity is beyond the scope of this article.

${ }^{7}$ Betton et al (2013) finds a substitution effect on the US market for corporate control, where there is no mandatory rule or bid price restrictions.
} 
implications of empirical results are discussed in section 4. The final section provides our conclusion.

\section{Data and sample selection}

Our initial sample includes all the takeover bids approved by the CNVM between $1^{\text {st }}$ of January 1998 and $31^{\text {st }}$ of December 2012. As no standard database exists, we collect information on 1,945 transactions by confronting several sources of information: (1) CNVM takeover lists and weekly official bulletins; (2) Bucharest Stock Exchange (hereafter BSE) electronic data; (3) the news database of S.S.I.F. TRADEVILLE; (4) Bursa newspaper that publishes a large number of takeover public announcements. For a given bid we compile data from those sources ${ }^{8}$ about the (1) CNVM approval date; (2) bidder's identity; (3) number of shares that are object of the bid; (4) final bidding price; (5) beginning date; (6) closing date; (7) price amendments; (8) bidding period amendments; (9) number of tendered shares and; (10) final ownership of the bidder. We exclude from the analysis the buyback offers, the clean-up transactions organized after 2005 and formally identified as such by the CNVM and the bids made for targets from the financial sector.

We define the initial and final takeover premium by scaling the initial and final offer price, respectively, by the target stock closing price 35 days prior to the reference date. ${ }^{9}$ The reference date is the day the CNVM approves the takeover. ${ }^{10}$ The market prices were sourced from the S.S.I.F. ROMINTRADE.

The tender offer outcome is the percentage of shares tendered within the bid with respect to the number of shares that the bidder wants to acquire according to the tender offer document. An

\footnotetext{
${ }^{8}$ None of our sources of information covers completely the takeover contests. For example, the weekly bulletins of CNVM (comprising all the decisions made by CNVM) are available beginning with 2003, the BVB electronic summary includes the bids made after 2005, while the BVB repository is used on a regular basis for filling the closing reports after 2006 and the full takeover documents especially after 2011.

${ }^{9}$ As the historical bid-ask spreads are not available, missing transaction prices are replaced by the previous closing price.

${ }^{10}$ Replacing the CNVM approval date with the first of the two following dates: (1) the date of the preliminary announcement of a bid (2) the date the market trades with the target shares are suspended by the CNVM, does not change the results.
} 
offer succeeds if, according to the closing report, at least one share is tendered by the target shareholders and purchased by the bidder while it fails if no share is tendered.

Of all transactions we are able to compute the takeover premium for 1,730 deals and the takeover success for 1,814 deals. If there is no information about the bid closing or no market transaction involving the target shares before the approval date those observations were dropped from the final samples. These final samples, described in Table 1, represent about $90 \%$ of all bids made over the analyzed period.

\section{$\{$ Insert Table 1 about here $\}$}

Table 2 reports means, standard deviations and quartiles for the takeover premium and bid success on the whole samples and classified by year. The peak values of takeover premiums are winsorized at $95 \%$ levels. As revealed by the mean takeover premium of $124 \%$ and the median of $27.7 \%$ wide variation remains. A quarter of the bids was initially made at a discount with respect to the market price and was amended till closing by a tiny $1 \%$ positive premium. When grouped by year, the summary statistics shows that takeover premiums varied a lot and, on the average, the highest compensation was offered in 2004, a year when some important changes were made to the takeover regulation. Afterwards the takeover premium began to decline to $6.5 \%$ in 2012 . However, the tender success had been decreasing over the analyzed period, a trend that becomes obvious when expressed in median values.

\section{\{Insert Table 2 about here\}}

In order to better discern the takeover outcomes we match the approval date of each bid with one of the regulatory regimes governing takeovers and stock market transactions in Romania. We identify ten different regulatory regimes based on the details regarding the conditions under which the controlling stake can be acquired, a public company can be delisted, and the main aspects defining the anti-dilutive statute namely, preemptive rights, minimum issue price, and shareholder approval rights. 
Regulatory regime 1. According to the initial takeover rules, any bidder who wanted to acquire the majority stake (50\%) in a public company should make an offer for all outstanding shares at a uniform price. However, there is no special minimum price condition and the circumstances justifying a delisting decision concerned size and liquidity issues of the target. ${ }^{11}$ Besides, the offeror aiming to acquire a controlling position (33\%) without exceeding the majority position $(50 \%)$ was allowed to make a partial bid and to allocate pro-rata the tendered shares in the case the offer was oversubscribed. Compared with all the other legal regimes, the takeover regulation before mid of 2002 is the most permissive one. Almost $50 \%$ of the bids took place in that regime.

Regulatory regime 2. In April 2002, a more comprehensive securities regulation defines for the first time a going private transaction with respect to the $90 \%$ threshold of the total voting rights and sets restrictions on the rival bids (size of the rival bid, price auction, unique closing date for all rival bids) and acquirer actions (no subsequent offer within 12 months after the bid closing). The regulation puts in place multiple threshold crossing triggers restricting increases in ownership over $75 \%$ of the voting rights without making a takeover bid. Without providing any particular justification, the new regulation states that the acquisition of control following a deal with AVAS or the purchasing of securities from the Ministry of Public Finance during the process of enforcing the receivables held by the State budget fall within the scope of exemptions. During this regulatory regime, the General Assembly of Shareholders of listed companies could not cancel the preemptive rights of their shareholders.

Regulatory regime 3. Several months later, a new market law settles the previous rules applicable to the mandatory bids but makes some changes of the standards concerning the buyout price. According to this regulation, the controlling shareholder with more than $90 \%$ of outstanding shares has the obligation to buyout the minority holdings. Besides, it is recognized for the first time that the minority shareholders owning at least $5 \%$ of the share capital have the right to contest the buyout price. Another important change made during the third regime concerns a larger scope of in-kind contributions. Particularly, the investors having assumed explicit contractual obligations during the privatization managed par AVAS can increase unilaterally their

\footnotetext{
${ }^{11}$ A company could be delisted if after the bid closing, the target had less than 500 shareholders or its share capital was lower than 1 billion ROL.
} 
ownership in a public company by capitalizing their investments consented in the privatization contracts.

Regulatory regimes 4, 5 and 6. In less than a year, new regulations addressed the thorny question of the fair price standards in the special case of delisting and the way of dealing with the conflicts between the acquirer controlling the target and its minority shareholders. CNVM enacted alternative valuation rules, e.g. appraisal based on fundamental values, market based valuation or valuation based on the previous purchases by the acquirer and various combinations of these benchmarks, e.g. a single value, the average or the maximum among two or three price criteria. Beginning with the sixth regime, the shareholders owning at least $75 \%$ of the targeted shares could contest the bidding price within the 10 days after the announcement date (at least 30 days before the biding period) and hire a second expert to assess a new price.

Regulatory regime 7. The takeover regulation from 2003 imposed for the first time a minimum price condition in the case of the mandatory bid rule for $50 \%$ of the voting rights. Thus, the minimum price is the highest price paid for the same securities by the offeror, or any person acting in concert with him, over the 12 months preceding the bid. It adjusts once more the benchmark for buyout price.

Regulatory regime 8. Following the prescriptions of the European Takeover Directive, the Market Law of 2004 modifies the MBR trigger from 50\% to 33\%, reducing the scope of partial offers. The regulation makes no longer any reference to intermediate thresholds of $50 \%$ or $75 \%$ of voting rights. A minimum price criterion (meanwhile slightly changed) is maintained for the acquisition of a controlling block. It also states that the bidding price paid in a previous mandatory bid or voluntary bid when at least $90 \%$ of the targeted shares were tendered, taken that the offeror makes use of its squeeze-out right within the 3 months following the closing of the previous takeover bid, is a fair buyout price. Minority shareholders receive an explicit sell-out right, if a controlling shareholder owns at least $95 \%$ of the voting rights. One new important legal detail related to the balance of power between large and small shareholders, which falls outside the bounds of takeover regulation, is the possibility to cancel the preemptive rights of 
shareholders when shareholders owning $75 \%$ of the voting rights vote in favor of such a measure at the extraordinary shareholders' meeting.

Regulatory regimes 9 and 10. The last two regulatory regimes restate the fair price standard in the case of squeeze out offers, as advised in the European Takeover Directive, but change the computation method of the minimum bidding price when the acquirers bought no shares of the target in the period preceding the bid. If no acquisition by the offeror took place in the previous 12 months, the price must be at least equal to the value of the net asset per share according to the last financial statement of the issuer. Starting with July 2005, a new sale-out procedure forces the minority shareholders to sell their shares to a major shareholder using his squeeze-out right. Finally, during those periods the Board of Directors of public companies receive more leeway when the shareholders of a public company do not use their preemptive rights and an equity issue remains undersubscribed. The main differences among those two regimes concern the rule employed to calculate the minimum bidding price for voluntary bids and the criteria applied when preemptive rights are canceled.

All in all, the nexus of regulations altering the positions of securities holders, deterring or speeding transactions are crucial for the assessment of the MBR and reveals the controversy surrounding the efficiency and fairness issues in control transactions. A mapping of those regimes is presented in Appendix 1, while descriptive statistics of the main dependent variables by regime are presented in Table 3.

\{Insert Table 3 about here $\}$

\section{Explanatory variables and testable hypotheses}

The next step consists of the identification of various aspects of the targets' corporate governance structure, bidder and deal characteristics that are likely to influence the acquisition premium and bid outcome. Descriptive statistics on those variables across categories of their major determinants is listed in Table 4. 


\section{Privatization premium benchmarks}

In order to investigate the link between the gradual decrease of Government ownership and takeover market involving exclusively private investors, we exploit the AVAS reports containing all negotiated deals. From a total of 11,034 transactions, we identify for 3,873 deals concerning listed companies and performed during their stock market episode the following information: (1) the privatization date; (2) the privatized block; (3) the share capital privatized by AVAS; (4) the amount paid by the buyer; (5) the currency of the deal; (6) the identity of the buyer. Based on those attributes we determine the privatization price per share and then the privatization premium by comparing the negotiated price with the market price available 35 days before the privatization date. The pricing benchmark for each takeover is computed as the moving average of the privatization premiums clustered by industry over 52 weeks preceding $t$ - 14 days, where " $t$ " is the date CNVM approved the takeover bid. We control the radial influence of privatization over the period 1998-2004, because the process of ownership transfer from State to private investors began to lose intensity, at least when addressed by industrial sector.

$\mathrm{H}_{1}$ : If bidders give any weight to historical privatization prices, we expect finding a positive relationship between the acquisition premium and the average privatization premium paid within the industry of the target.

\section{Equity changes and financial dilution}

For each target included in our analysis we check first whether there is any change of the share capital reported by BSE and collect the main information available on the (1) date of equity change; (2) number of outstanding shares before and after the equity event and; (3) face value before and after the equity event. Then, for each equity change performed before the bid date, we manually search information on their individual effect and the ex-post ownership structure in the news database of S.S.I.F. TRADEVILLE and BSE. ${ }^{12}$ At the bid date, from 1,096 unique targets,

\footnotetext{
${ }^{12}$ After 2005, a more detailed description of the type of equity changes becomes available also in the official reports of BSE. Besides, if there is no announcement about the ownership structure on the TRADEVILLE platform, we
} 
674 changed their share capital at least once, which means that $56 \%$ of takeover bids were preceded by 1,025 equity operations. Based on the description of equity event, we compound the degree of equity dilution inflicted to minority shareholders in function of the free float after the equity change and the reported effect. When the equity change consists of modifying the face value or represents a right offering, as well as a stock dividend distribution, there is a homogeneous effect of those operations on all shareholders of the issuing company. In such cases, the dilution is normalized to zero. However, when one of the target shareholder is explicitly identified in the announcement as being exclusively affected by the operation, usually the major shareholder or AVAS, or the description of the event point out to a capitalization of the investments consented into the privatization contract signed with AVAS, minority shareholders suffer a complete dilution of their rights, which depends on the size of the equity change. ${ }^{13}$ Thus, the financial dilution per equity change is computed as the ratio of (1) the difference between the ex-post free float and ex-ante free float divided by (2) the ex-ante free float. We recognize that the dilution consequences are more severe when the target is involved in several changes of equity capital, by compounding the dilution measure over all equity issues reported before the bid date.

$\mathrm{H}_{2}$ : If the acquirer seeks to enjoy the control at the minority shareholders expense, we expect that the higher the dilution, the lower the takeover premium and the higher the tender success.

\section{Toehold}

The toehold is the size of pre-offer ownership of acquirer, expressed in percentage with respect to the outstanding shares of target. Buying an initial capital before the takeover bid, ideally without arousing the market suspicion, is central to the bidding strategies. The toehold bidding is

\footnotetext{
check whether such information is announced on the BSE fillings within one-week following the equity date.

${ }^{13}$ If the announcement before the equity issue indicates a cum-right date for all shareholders while there is no available information on the beneficial owners, we ignore the partial dilution of minority shareholders arising when those participating in the equity offering have an "oversubscription privilege". Detailed reports about the number of shares subscribed and canceled with respect to the number of shares issued in exchange for cash needed for restoring the position of minority shareholders, are available only for the second half of the analyzed period. Atanasov et al. (2007) underline that the lack of participation of minority shareholders, even if the dilution rises, cannot be imputed to the major shareholder. The minority shareholders prefer not exercising their preemptive right if they anticipate being frozen-out at large discounts.
} 
beneficial because it reduces the amount paid for the remaining shares and provides a competitive advantage over the rival offers. Betton et al. (2007) show that there is a decreasing trend in the level of toeholds of acquirers in US targets and despite the theoretical arguments in favor of positive toeholds those ones are rare in mature markets. ${ }^{14}$ In our sample, from 1,696 bids for which we were able to collect information on toehold, only $20 \%$ of the bidders do not have a toehold. In order to control for the non-linearity of the bidder's ownership, we partition our sample across toehold categories. Conditional on positive toeholds, we include indicator variables equal to one whenever the bidder toehold falls within the following four ranges: $0 \%<$ toehold $<$ $33 \% ; 33 \% \leq$ toehold $<50 \% ; 50 \% \leq$ toehold $<90 \%$; and toehold $\geq 90 \%$. Moreover, we construct a "novel control" dummy variable, by breaking down the direct toehold with respect to the legal control definition, namely 50\% (regulatory regimes 1 to 7 ) and $33 \%$ (regulatory regimes 8 to 10 ). We consider that an acquirer holds a novel controlling position if he crosses the minimum legal stakes after the closing of the bid.

\section{AVAS foothold}

The targets included in our analysis were involved in 1,908 privatization transactions before the bid date, 402 deals being made with the bidders. In 208 cases the bidder bought a majority foothold from AVAS. The long-term toehold is viewed as an entrenching dimension of governance at target level. Its influence is controlled in our analysis by identifying the bids proffered by investors that had previously dealt a block directly with AVAS.

\section{Short-term toehold}

By the end of 2004, BSE created a publicly available electronic repository allowing the issuers to fill reports containing information on the (1) identity of the registered insider; (2) date of the transaction made by an insider; (2) nature of the transaction; (3) volume of the traded stocks; (4) transaction price; and (5) value of transaction. As the database is not readily exploitable, we hand-collected all the reported daily insider transactions for the subsample of acquisitions announced between 2006 and 2012. Thus, after the enforcement of this new disclosure

\footnotetext{
${ }^{14}$ The reader can refer to Betton et al. (2008) for a comprehensive review of the literature on corporate takeovers.
} 
requirement we sampled manually over 8,000 transactions reported by insiders of target firms and we identified 1,697 transactions that took place during the year preceding the bid date.

Based on those reports, we construct a short-term toehold proxy capturing the percentage of target shares amassed directly on the market or via share block trades ${ }^{15}$ during the 52 weeks before the bid. ${ }^{16}$ The accumulation of target shares ahead the takeover announcement creates an explicit cost for the insiders if they must or decide to pursue the increase in the ownership with a subsequent bid for all outstanding shares. Such a cost is due to the legal obligation to establish a biding price at least equal to the maximum price paid for purchasing the target shares during the 12 months ahead the bid. Under the pressure of legal constraints, the acquirers would have the interest to reduce purchases before the announcement, even to increase sales that not make them fall under certain thresholds. Besides, the insiders who had involuntarily increased their stakes in the targets after an equity increase could decide to sell the extra-number of shares. If such, the acquirers should be net sellers instead of net buyers and the strategy of stock price manipulation more likely in the case of controlling shareholders. ${ }^{17}$ However, the rationale of this disclosure standard is to avoid the transfer of the control block from another insider or from the controlling shareholder to a new investor at a premium over the price for remaining shareholdings. When the ownership distribution is rearranged by explicit dealing before an open bid, we should observe a net buying position for the acquirer and a net selling position for the other insiders.

The effect of the transactions made by insiders on the initial acquisition premium is apprehended by the following variables: (1) the short-term direct toehold calculated as the net purchase made by acquirer over the number of outstanding shares of target; (2) the net selling by other insiders, which is a dummy variable taking the value of 1 if the total selling is higher than the volume purchased by insiders, others than the bidder; (3) the 52-week High bidder paid, a dummy variable which takes the value of 1 if the highest market price over the 52 weeks preceding the bid is equal to the highest price paid by the acquirer over the same period.

\footnotetext{
${ }^{15}$ Toeholds smaller than the threshold requiring a substantial shareholder notice can not be captured in our analysis.

${ }^{16}$ In the empirical studies documenting the timing of toehold purchases (Betton et al. 2013; Aspris et al. 2014), the "short-term" period ranges from 30 to 42 days, which corresponds to the run-up period analyzed in those studies.

${ }^{17}$ The surplus over the controlling stake (33\% after 2004) is a buffer for manipulating the market price. However, such a strategy should not create a "false market" in the securities of target.
} 
In all cases, we perform the same analyses by replacing the direct toehold with the indirect toehold, which takes into account the ownership of the persons acting in concert with the acquirer. The takeover literature reveals that one expects a negative influence of toeholds on the takeover premium. However, because of their high frequency, the large direct and indirect toeholds are noisy and cannot be decoupled from the identity of acquirers. We take into account the heterogeneity of expropriation technologies across shareholders by constructing 8 categories of acquirers: (1) individual investor; (2) domestic joint stock company; (3) domestic limited liability company; (4) foreign company; (5) financial investor; (6) financial investment company; ${ }^{18}(7)$ group of more acquirers; (8) other types.

$\mathrm{H}_{3}$ : The higher the direct or indirect toehold, the lower the acquisition premium and the lower the tender success.

\section{Rival offers and bid revisions}

According to Fishman (1988), if the control is priced strategically, the targets attracting rival offers should receive a lower initial premium that those paid by uncontested bidders. This insight is questioned by Betton et al. (2013) who found that, when a rival bid decides to compete, the initial offer premium plays no deterring role. However, under the pressure of competition, the bidders adjust more aggressively the final price or extend the acceptance period leaving considerable leeway to target shareholders to opt for one of the bids. We define a rival offer as a tender offer that begins before the closing of a previous bid for the same target. Price revision is the ratio of the final and initial acquisition price, respectively, while the acceptance period revision is an indicator variable equal to one if the bidder modified the initial closing date. Approximately $9 \%$ of the bids are contested, a price auction sequence is recorded in more than $17 \%$ of the bids, while the acceptance bid period was extended in $21 \%$ of individual bid observations. The higher frequency of bid revisions challenges the presumption of passivity of minority shareholders in some targets, even if no rival arrives.

\footnotetext{
${ }^{18}$ Those companies are the former five private privatization funds founded by political decision in 1993.
} 
$\mathrm{H}_{4}$ : Contested bids are completed at higher acquisition premium but the overall success is lower.

$\mathrm{H}_{5}$ : The bid revisions have a positive impact on the tender success.

The introduction of formal corporate governance and transparency requirements, the updating of the takeover regulation to new standards, are deemed to improve the bargaining position of minority shareholders. If this conjecture already attested for European markets (Rossi and Volpin, 2004; Andersen et al., 2009) and for the New Zealand (Marshall and Anderson, 2009), is generally true, the following hypothesis should be validated:

$H_{6}:$ The more stringent the takeover regulation, the higher the tender premiums and bid success.

Appendix 2 summarizes these definitions and the measurement of all variables. Several welldocumented determinants of takeover premiums, like the payment method and the hostility of the bid are irrelevant in our context. All takeovers are cash-bids and opposed bids are anecdotal.

\section{Empirical analysis}

\subsection{Bivariate analysis}

In Table 4, we examine the acquisition characteristics by splitting observations in two groups based on the size of different explanatory variables.

\section{\{Insert Table 4 about here $\}$}

First we check whether there is any significant difference between the takeovers made by bidders with no prior ownership in the targets and those made by one of the target's shareholders (Table 4.a.). On average, the new acquirers pay an initial premium of $148.7 \%$, which is significantly higher than $120.0 \%$ offered by bidders that take prior ownership positions in their targets. The same significant relationship holds for the average final premiums, as well as for the bid outcomes. Conditional on positive toeholds, the initial and final premium are significantly higher, 
on average, when the bidder already owns the majority but the difference is insignificant when median values are considered instead (Table 4.b.). When we breakdown the direct toehold with respect to the legal control definition, we find that novel controlling shareholders pay finally as much as pre-existing controlling shareholders, even if, on average, their initial proposition was lower than the premium offered by controlling shareholders of targets (Table 4.c.).

We also construct a sub-sample of 324 bids where the ownership of bidders exceeds $90 \%$ but the transaction is not reported as a clean-up transaction. The initial and final premiums for those transactions are compared with those paid in takeovers, which, if some criteria are met after the closing, provide the acquirer with the right to buyout all remaining shares at the same price. The bivariate results showed in Table 4.d., "Toehold $\geq 90 \%$ " vs. "Squeeze-out" show that minority shareholders receive a higher premium in standard bids than in forced stock sales. The mean difference is $179.7 \%$ and is strongly significant at $1 \%$ level. This result raises the issue of whether the potential acquirers strategically shape their bidding strategy to the legal constraints addressing delisting, by systematically lowering the takeover premium in previous stages, likely to get them over the threshold of $90 \%$ of outstanding shares.

In increased-in-ownership M\&A type, a term coined by Croci and Petmezas (2010), the controlling shareholder could previously acquire a block by trading directly with AVAS. If the sole motivation behind the decision of crossing the $50 \%$ threshold had been the extraction of private benefits of control at the minority shareholders expense, those investors would had never chosen to make any subsequent voluntary bid. ${ }^{19}$ We construct two groups, majority vs. minority foothold (Table 4.f.), based on the maximum block sold by AVAS in all the privatization rounds organized before the bid date. Controlling shareholders possessing the majority foothold make higher offers than non-controlling bidders that had previously bought AVAS minority blocks (214.3\% compared to $169.4 \%$ ). Such a result makes us infer that the market price could adjust in response to such changes in ownership structures. Indeed, negotiations of a minority block facilitates takeover target prediction, while a further increase in the ownership over the threshold fully empowering the shareholder is more likely to come as a surprise.

\footnotetext{
${ }^{19}$ As the MBR is not triggered after a privatization transaction, even if the legal threshold is reached, a bid for the remaining shares is up to the controlling shareholder.
} 
Bearing in mind the magnitude of the privatization phenomenon, we refine the analysis of the impact of the major shareholdings built-up by circumventing the stock market on the scope of shareholder protection by comparing the premium paid for the targets already controlled by the bidders to those offered for targets dominated by other insiders who dealt with AVAS. The bivariate results reported in Table 4.g. show that even if the controlling bidders pay a significantly higher premium (232.2\%), the minority shareholders accept more largely the bidding terms in targets controlled by other dominant shareholders $(34.2 \%$ vs. $28.6 \%$, on average). As a majority owner cannot be removed without being compensated for the loss of private benefits, such a result raises the question of the rationale behind a takeover initiated by a third-party acquirer at less favorable relative terms. If we suppose that higher governance standards lead to lower private benefits of control, an incumbent owner should sell out and consequently the tender success should exceed $50 \%$ in those cases. As it does not seem to be the case, the tender decision of minority shareholders in targets dominated by large shareholders, others then bidders, provides support to the pre-emptive theory of Högfeldt and Högholm (2000). The minority shareholders facilitate the emergence of a pivotal shareholder because the implicit threat of blocking a future delisting drives up the premium in full-acquisitions. Besides, the higher premiums received by target shareholders from controlling bidders, which would have been able to quietly consummate their prerequisites after buying the majority stake from AVAS, ${ }^{20}$ could signal an increase in the shared benefits of control due to unexpected good performance and a fostered interest in delisting the target. ${ }^{21}$

The targets attracting competition receive, on average, a premium of $157.0 \%$, significantly higher than that offered in single bids. The significant difference between the two means (Table 4.i.) questions the preemption argument of Fishman (1988), given that the bid is contested at least once. Bearing in mind that, according to the regulation, the minimum tender offer is of approximately 3 calendar weeks and no tender offer is valid without the CNVM approval, a quick

\footnotetext{
${ }^{20}$ Burkart et al. (1998) show that acquirers would never voluntarily choose to exceed the minimum control threshold because at this level the extraction of private benefits at the expense of the minority shareholders is maximum.

${ }^{21}$ Croci and Del Giudice (2012) found that compared with the effects of other public to private transactions, the abnormal returns are lower in the case of buyouts made by controlling shareholders but they do not explicitly check whether the raw compensation offered to minority shareholders is adequate. A large stream of the literature considers delisting carried out in strong corporate governance environments as being a manifestation of the good protection of minority shareholders (see also Thomson et al., 2013).
} 
arrival of a new bid could signal that competing bidders had already performed their private valuations of the target when the first offer was launched. The magnitude of bid revision when at least two bidders compete for the target almost double compared to initial terms (299.0\%) and is significantly higher than the final bid premium (169.2\%) offered by uncontested bidders. The competition on the market for corporate control affects negatively the reception of the contested bids.

The bivariate analysis of the initial takeover premium contrasting strategies with no price revision (Table 4.j.) to those when the bidding price was raised till completion is in line with the empirical findings of Betton and Eckbo (2000), Betton et al. (2007). The offer premium in tender offers completed without amending the price (128.8\%) is significantly higher, on average, than the first premium in a sequence of revised pricing terms (100.5\%). Moreover, the significant jump between the first bid and the final bid of $258.4 \%$ improves significantly the reception of the tender offer by the remaining shareholders. On average, the tender success increases from $34.3 \%$ for an offer completed at the price mentioned in the initial takeover document to $49.4 \%$ when the bid is amended.

When we perform the same analysis with respect to the takeover period revision (Table 4.k.), the tests of mean and median differences show that the acquirers who decide to extend the tender validity period in reaction to a low supply of shares pay initially a significantly lower premium than those who close the offer on time. However, when the acquirer decides also to increase the bidding price after the bid initiation, a longer tender period is associated with a higher price revision according to the median values (63.9\% vs. 38.89\%). Nevertheless, a tender offer that remains open for a longer period does no not attract more minority shareholdings, $38.0 \%$ on average which is not statistically different from $36.1 \%$ tendered during the standard acceptance period.

Finally, we separately examine acquisitions for the targets that were not involved in any equity operations and those that experienced such changes (Table 4.1.). As an equity change provides opportunities to realize wealth transfers from minority shareholders, belonging to the last group could be consistent with financial expropriation. The shareholders that were more likely to have 
wealth tunneled away from them receive, on average, a final premium of $158.5 \%$. The high level of absolute acquisition premium does necessarily point to a "bad" acquisition but, compared to that offered to the targets not suspected of financial maneuvers, it is significantly lower at $1 \%$ level. Besides, this corporate governance attribute impacts significantly the offer success.

\subsection{Regression analysis}

In order to further examine the initial insights provided by the bivariate analysis, we explore the relationship between the acquisition premium and the selected determinants in several multivariate settings. The general form of the regression models are as follows:

$$
\begin{aligned}
\text { Initial bid premium }= & a_{0}+a_{1} \cdot 52-\text { High }+a_{2} \cdot \text { Financial dilution }+a_{3} \cdot \text { Toehold }+ \\
& +\sum_{i} b_{i} \cdot \text { Regulatory regime }_{i}+\sum_{j} c_{j} \cdot{\text { Acquirer's } \text { type }_{j}+\epsilon_{i}}^{\text {Acquires }}
\end{aligned}
$$

As our measures of the (initial and final) acquisition premium exhibit large variations, especially at the upper tail of the distributions, we control for outliers in several alternative ways. First, we winsorize the acquisition premiums at the 95\% level. Second, we exclude all the observations higher than the $95^{\text {th }}$ percentile of the distribution of the acquisition premium. Third, we use a robust estimation technique based on iteratively reweighted least squares, which assigns lower weights to observations with large residuals, making the estimation less sensitive to outliers. Standard errors are calculated using the pseudo-values approach described in Street, Carroll, and Ruppert (1988). Fourth, to further test the sensitivity of the results with respect to the modeling choice, we also estimate median least squares (least-absolute-value) regressions. The median least squares estimator minimizes the absolute deviations from the median and thus reduces the effect of outliers (see Koenker and Bassett, 1978). Standard errors are calculated in this case using the bootstrap method based on 1,000 replications.

Table 5 summarizes the results from OLS regressions for the initial bid premium (models 1 to 5) and final ones (models 6 to 10). The regressions incorporate corporate governance and ownership attributes of the target, as well as variables corresponding to the nine regulatory regimes 
governing takeovers. The first regulatory regime was drop out from the regressions for avoiding multicoliniarity in the data.

\section{\{Insert Table 5 about here $\}$}

The results indicate that the level of acquisition premiums depend strongly on the highest price paid during the year preceding the bid. The effect of 52-week High is robust across various regulatory regimes and model specifications, corroborating the recent findings of Baker et al. (2009), Suzuki et Kruse (2010) and Betton et Eckbo (2013).

Surprisingly, we find that the marginal variations in corporate governance regulations have a negative valuation effect compared to the benchmark regime. The effects become significantly stronger after the seventh regulatory regime. As, at that date, the controversy surrounding the buyout price metrics and delisting conditions had been engaged for a long time without any significant influence on the acquisition premiums (the coefficients of regulatory regimes 2 to 6 are not statistically different from zero in some specifications), such an effect is likely to hint that the rule dictating the magnitude of the consideration involved in a mandatory bid does not add any value to minority shareholders. A similar argument could be evoked in the case of the reduction of the threshold triggering a mandatory bid at 33\%, which was enacted into domestic regulation in 2004 without any apparent justification (regulatory regime 8). The point estimates, significant at $1 \%$ level, provide empirical support to the theoretical insight of Luh et al. (2001) arguing that changing the mandatory takeover thresholds has welfare implications on parties involved. However, the negative influence of regulatory regimes imposing stricter takeover conditions remains open to different interpretations. Bebchuk et al. (2010) argue that investors have become acquainted with the governance quality making disappear the governance-returns correlation. Consistent with learning hypothesis, the trading reflects fully the legal developments thus raising the overall level of market prices. Luh et al. (2001) posit that when the share price formation process is dependent on the mandatory takeover threshold there is a positive relationship between those thresholds and the bid premium. As the significant effect of the highest price persists in the cross section analysis of acquisition premiums, the negative coefficients of regulatory regimes should reflect influences beyond the patterns of returns. 
Besides, other aspects connected with the quality of corporate governance at the target level, which structurally fall outside the MBR, have little power in explaining bid premiums. Financial dilution and ownership entrenchment proxies are not statistically significant. Our findings indicate that a better overall governance could be undermined by a general sentiment of overregulation.

The direct and indirect toehold is negatively correlated with the acquisition premium. When we break down the direct toehold by category, this statistical relationship survives only for the bids made by acquirers controlling at the bid date more than $90 \%$ of the target equity (model 5). However, the significant negative coefficients of minority toeholds $(0.0 \%<$ direct toehold $<$ $33.0 \%)$ and $(33 \% \leq$ direct toehold $<50.0 \%)$ in the specification accounting for the effect of indirect holdings (model 10) implies that acting in concert is a relevant feature of the bidding framework. It also suggest that when bids are structured for buying out minority shareholders by acting in concert with other investors instead of disguising a pending deal with a substantial shareholder, bidding price is a poor investor protection mechanism.

Once that the bid is in play, the acquisition premium increases in the presence of multiple bidders. The coefficient of the dummy variable "Rival" is positive and highly significant in all regressions.

The median robust estimations replicate the main results reported in Table 5, showing that the influences are not driven by outliers. While the various toehold measures are no longer significant, differences in the type of acquirer explains variation in acquisition premiums. Thus, foreign companies and institutional investors pay for having the control, on average, more than individual investors. Even if the families play an important role in other blockholder regimes from continental Europe, the experience of private entrepreneurship is too tiny in emerging markets for supporting expensive acquisitions.

\section{\{Insert Table 6 about here $\}$}


We further address the concern that bidders could pay attention to the price solicited by the Government for its ownership in companies belonging to the same industrial sector. We reexamine whether previous statistical relationships remains valid after controlling the original effect of privatization for a sub-sample comprising all the bids organized between 1998 and 2004. The results in Table 7 show that parallel control transactions are influential in the acquisition pricing decision. This wealth effect adds up to the pricing triggered by the stock market. The higher the premium paid for AVAS block in the period preceding the bid, the higher the bid premium proposed to minority shareholders. As on average the privatization premium is twice as high as the acquisition premium, this effect remains less powerful than a direct influence expected when the terms of "excepted transactions" would have been extended to all shareholders.

\section{\{Insert Table 7 about here $\}$}

Finally, in Table 8 we rerun the regressions of initial bid premiums against variables related to acquisition strategy of the bidder. The sub-sample of observations covers only the offers made in the last two regulatory regimes making us neglect in the estimations the influence of legal provisions. The median regression coefficient estimates provide no evidence that the ownership related variables result in higher takeover premiums. The acquirers that purchased a portion of their toehold before the bid do not pay a significantly lower premium than those with no market activity. While the quantities amassed on the market plays no significant role (the coefficient of short-term toehold is not significant), the influence of pre-bid strategy could be exerted over the market price. Indeed, the coefficient of the variable indicating the highest price was actually paid by the bidder itself is negative, while the effect of the 52-week High benchmark remains positive. Such a result make us infer that the presence of other insiders facilitate the bids and improve the ability of acquires to bargain for control before the tender offer is made to remaining shareholders. This result corroborates the findings of Gaspar et al. (2005) showing that the investors having a short investment horizon negatively impacts the target premiums.

\{Insert Table 8 about here $\}$ 
As far as the bids are not coercive, shareholders of the target are better placed to judge their merits. For explaining the bid outcome, we estimate Generalized Linear Models (GLM):

$$
\begin{aligned}
& g\{\mathbb{E}(\text { Bidder outcome })\}= \\
&= a_{0}+a_{1} \cdot \text { Final bid premium }+a_{2} \cdot \text { Bid jump }+a_{3} \cdot \text { Period revision }+ \\
&+a_{4} \cdot \text { Rival }+a_{5} \cdot \text { Financial Dilution }+\sum_{i} b_{i} \cdot \text { Regulatory regime }_{i}+ \\
&+\sum_{j} c_{j} \cdot{\text { Acquirer's } \text { type }_{j}}^{\text {Acquat }}
\end{aligned}
$$

where the link function $g(\cdot)$ is the logit function and the dependent variable is distributed as binomial.

Our modeling choice is a better alternative to Ordinary Least Squares (OLS) regressions because the dependent variable (bid outcome) is a proportion that falls between zero and one. The various models are fit by using maximum likelihood (Newton-Raphson) optimization routines (see Dobson and Barnett, 2008, for a concise introduction and overview). For computational reasons, the bid outcome in the GLM models is expressed as coefficient comprised between zero and one and not as percentage.

Among the factors with significant influence on the bid outcome we recognize some that are consistent with the empirical research regularities: the level of the final premium and the extant of bid revisions, which improve the perspective of a bid success and the existence of competing bidders, which make the bid failure more likely (Walkling, 1985; Betton and Eckbo, 2000; Henry 2004; Bates et al., 2006). Compared with some existing contributions revealing the predictive ability of those determinants, we explain in the regressions presented in Table 9 the actual percentage tendered by remaining shareholders. Our definition of bid success is more accurate and highly relevant for the analyzed context where a bidder may buy even a single tendered share and structure a sequence of bids.

The coefficient of the financial dilution is positive and significant but only when the effect of initial ownership of bidders is neglected. This result shows that minority shareholders prefer to quit poor-governed targets. The remaining shareholders facilitate the emergence of novel controllers and prefer tendering more to foreign companies which are less likely to be engaged in 
existing expropriation schemes. Besides, the target shareholders tender less shares to bidders that already possess stakes in the target and their marginal reluctance become greater for toeholds exceeding the legal control thresholds.

The highest the difference between the bidding price and the highest market price reported during the relevant period, the higher the tender success. As in the bid premium regressions, the coefficient of that variable is positive and highly significant in all specifications. Even if the regulation enhances the protection of minority shareholders, we find that the legal improvements, especially those inspired by the European Takeover Directive, lead to poorer tender success.

\section{Conclusion}

In the European emerging economies, market authorities have been obviously concerned about the protection of minority shareholders' interests. However, our study shows that the evidence is not always in line with the well-intentioned beliefs subscribed by the regulators.

The main conclusions about the effectiveness takeover regulation as governance mechanism are derived by analyzing the acquisition premium and the tender success of more than $90 \%$ of the takeovers organized in Romania between 1998 and 2012. The statistical significant negative effect of some regulatory regimes on the level of acquisition premium point to the fact that lowering the thresholds specifying the triggering events under the hard control level $(50 \%$ of the voting rights) may compromise the minority shareholder protection objective. Besides, the transposition of public takeover regulation framed at the European Union level has been accompanied by a poor analysis of the domestic institutional structures, often beneficial to large shareholders. The specific conditions in which companies were privatized, the conduct of Government in its capacity as shareholder unveil that corporate diversity goes beyond the traditional classification of ownership structures with respect to the size of shareholdings or mechanisms separating cash-flow and voting rights. A deeper analysis of the peculiar legal provisions added into the national takeover regulations and the interactions among various forms of control transactions raise the question of whether the rationale of tailored exemptions is ultimately linked to the stated interest of the Takeover Directive. An important step in emerging 
markets where majority shareholders avoided any market scrutiny is to admit that conforming expost to the takeover rules and standards would not render the control contestable. Our empirical findings related to the minority shareholder tender decision make us wondering whether the focus of takeover regulation on the price standards is not misplaced. The minority shareholders seem to take into account not only traditional market benchmarks but also various corporate governance features when they are facing takeover attempts.

The protection is enhanced precisely when the unconstrained tender decisions are able to insulate minority shareholders from opportunistic incumbent blockholders acting as acquirers. The analysis of the practice in other European jurisdictions unfolds that some precautionary measures has never been addressed by the detailed rules in spite of the numerous amendments made to the Romanian takeover regulation. Several policy implications of such a comparison are straightforward. First, the introduction of a minimum acceptance in the case of voluntary and mandatory bid and the enforcement of "majority of minority condition" for closing a buyout would reduce the flexibility of large shareholders to structure creeping acquisitions. Second, more stringent anti creeper provisions should cover the usual market transactions by limiting further increases in acquirer's holdings within a specified time frame after the closing of a bid. Finally, the definition of post-bid top-up clauses could reduce the scope of ex-post bargaining with selected minority investors. According to such a restriction, an offeror, who buys additional securities on the market after the closing of the bid, must extend a market price higher than the acquisition price to all recipients of a previous public bid. Consequently, a key aspect of an adequate investor protection is to clarify and reveal the identity of those minority shareholders who accept the bid terms. Adding in the closing report, besides the final ownership of acquirer, information regarding the new ownership structure of the target, as well as details about the tendering decision of important minority shareholders would force large shareholders to internalize the countervailing effects of their discretionary behavior or misconduct.

The scope of the extraction of private benefits in emerging markets point to a general feature of the corporate environment rather than to private abilities to divert resources. If this practice is not bidder specific, it makes little sense to promote the MBR in those economies on the ground that it prevents transfers to less efficient managers. Moreover, it is likely that the inconvenient of this 
rule (the decrease in the number of enhancing-value bids) outweighs its advocated advantage (impeding of value-decreasing bids). The dramatic contraction of stock markets must make the genuine phenomenon of corporate restructuring go hand in hand with a more important due diligence and a search for solutions preserving the channel of external financing.

\section{Acknowledgements}

We are indebted to Azizjon Alimov, Paul Frentrop and participants at the 1st Academic Conference of the International Corporate Governance Network, the 6th International Conference of the International Finance and Banking Society and the 2014 Annual Conference of the Asian Finance Association for useful comments and suggestions; The Romanian Privatization Authority, The Romanian Financial Supervisory Commission, Tradeville, Romanian Universe for helping with data. A. Pop gratefully acknowledges financial support from the Chaire Finance of the University of Nantes Research Foundation. D. Pop gratefully acknowledges financial support from the Rules and Markets Chaire - GRANEM of the University of Angers. 


\section{References}

Aspris, A., Foley S., Frino A., 2014. Does insider trading explain price run-up ahead of takeover announcement. Accounting and Finance, 54, 25-45.

Alexandridis G., Petmezas D., Travlos N.G., 2010. Gains from mergers and acquisitions around the world: New evidence. Financial Management, 394, 1671-1695.

Anderson H.D., Marshall B.R. and Wales R., 2009. What is the relationship between investor protection legislation and takeover returns? Evidence from Europe. Journal of Multinational Financial Management, 19, 291-305.

Atanasov, V., Ciccotello, S.C., \& Gyoshev S.B. 2010. How does law affect finance? An examination of equity tunneling in Bulgaria. Journal of Financial Economics, 96, 155-173.

Baker M., Pan X., Wurgler J. 2012. The effect of reference point prices on mergers and acquisitions. Journal of Financial Economics, 1061, 49-71.

Bebchuk, L..A., Cohen A., Wang C., 2010. Learning and the disappearing association between governance and returns, Discussion Paper No. 667, Harvard Law School John M. Olin Center for Law, Cambridge,

Berglöf, E., Pajuste A., 2003. Emerging owners, eclipsing markets: Corporate governance in transition. in Cornelius, P. K. and Bruce K. Eds.. Corporate Governance and Capital Flows in a Global Economy, New York: Oxford University Press, 267-304.

Betton S., Eckbo E., 2000. Toeholds, bid jumps and expected payoffs in takeovers. Review of Financial Studies, 13, 841-882.

Betton S., Eckbo E., Thorburn K., 2008. Corporate Takoevers. in B. Espen Eckbo Eds. Handbook of Empirical Corporate Finance, vol 2, Elsevier, 291-429.

Betton S., Eckbo E., Thorburn K., 2013. Merger Negotiations with Stock Market Feedback. Journal of Finance. forthcoming

Chemla, G., Pop A., Pop D., 2010. Privatization and governance regulation in frontier emerging markets: The case of Romania., in R. Bliss and G. Kaufman Eds., Financial Institutions and Markets, vol.3 The Financial Crisis: An Early Retrospective, Palgrave Macmillan.

Croci, E., Petmezas D., 2010. Minority shareholders's we lth effects and stock market developpement : Evidence from increase-in-ownership M\&A. Journal of Banking and Finance, 34, 681-694.

Croci, E., Del Giudice A., 2012. Delisting, controlling shareholders and firm performance in Europe. European Financial Management, forthcoming. 
Dobson, A.J., Barnett A. G., 2008. An Introduction to Generalized Linear Models. 3rd ed. Boca Raton, FL: Chapman \& Hall/CRC.

Faccio, M., Stolin D., 2006. Expropriation vs. proportional sharing in corporate acquisitions. Journal of Business, 793. 1413-1444.

Fishman, M.J., 1988. A theory of preemptive takeover bidding. Rand Journal of Economics, 19, $88-101$.

Gaspar, J.M., Massa M., Matos P., 2005. Shareholder investment horizons and the market for corporate control. Journal of Financial Economics, 76, 135-165.

Goergen, M., Martynova, M. and Renneboog, L. 2005. Corporate governance convergence: Evidence from takeover regulation reforms in Europe. Oxford Review of Economic Policy 21, 243-268.

Henry, D., 2004. Corporate governance and ownership structure of target companies and the outcome of takeovers. Pacific-Basin Finance Journal, 12, 419-444.

Högfeldt, P., Högholm, K., 2000. A law of finance .Journal of Corporate Finance 6, 403-425.

Jabbour, A.R., Abolhassan J., and Switzer, J.A., 2000. Pre-bid price run-ups and insider trading activity. Evidence fom Canadian acquisitons. International Review of Financial Analysis, 91, $21-43$.

Koenker, R., Bassett G., 1978. Regression quantiles. Econometrica, 461, 33-50.

La Porta, R. Lopez-de-Silanes F., Shleifer A., Vishny R., 1998. Law and Finance. Journal of Political Economy, 106, 113-1155.

Luh, L.L., Kee H.Y., Leng N.S., 2001. Mandatory bid rule: Impact of control threshold on takeover premiums. Singapore Journal of Legal Studies, 433-452.

Marshall B.R., Anderson H.D., 2009. Regulation and target takeover returns: Is there a link?. Pacific-Basin Finance Journal, 17, 395-412.

Pop, D., 2006. M\&A market in transition economies: Evidence from Romania. Emerging Markets Review, 7, 244-260 .

Rossi, S., Volpin P., 2004. Cross country determinants of mergers and acquisitions. Journal of Financial Economics, 74, 227-304.

Street, J.O., Carroll R.J., Ruppert D., 1988. A note on computing robust regression estimates via iteratively reweighted least squares. American Statistician 42, 152-154.

Subramanian G.. 2005. Fixing Freezeouts. The Yale Law Journal, 115 1, 2-70. 
Suzuki K., Kruse T.A., 2010. Two decades of development of tender offer market in Japan: An analysis of regulatory changes, offer premiums, and share price reactions. USJP Ocassional Paper 10-11.

Thomsen, S., Vinten F., 2013. Delisting and the cost of governance: A study of European stockexchanges 1996-2004. Journal of Management and Governance forthcoming.

Walkling, R.A., 1985. Predicting tender offer success: A logistic analysis. Journal of Financial and Quantitative Analysis, 20, 461-478. 


\begin{tabular}{|c|c|c|c|c|c|c|}
\hline 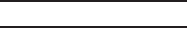 & Regime 1 & Regime 2 & Regime 3 & Regime 4 & Regime 5 & Regime 6 \\
\hline Period & $1 / 01 / 95-8 / 04 / 02$ & 9/04/02-4/08/02 & $5 / 08 / 02-24 / 09 / 02$ & $25 / 09 / 02-3 / 10 / 02$ & $4 / 10 / 02-29 / 11 / 02$ & $30 / 11 / 02-8 / 08 / 03$ \\
\hline Legal indicator & $\begin{array}{c}\text { Market Law 52/1994 } \\
\text { Takeover Regulation } \\
16 / 1996\end{array}$ & OUG 28/2002 & Market Law 525/2002 & Instruction 1 & OUG 122/2002 & OUG 165/2002 \\
\hline \multicolumn{7}{|c|}{$\begin{array}{l}\text { MANDATORY BID FOR ALL THE OUTSTANDING SHARES } \\
\end{array}$} \\
\hline $\begin{array}{l}\text { Controlling position } \\
\text { Majority Position } \\
\text { Qualified Majority }\end{array}$ & $\begin{array}{c}\mathrm{na}^{*} \\
50 \%+1\end{array}$ & $\begin{array}{c}\mathrm{na}^{*} \\
50 \%+1\end{array}$ & $\begin{array}{c}\mathrm{na}^{*} \\
50 \%+1\end{array}$ & & & \\
\hline Position & $\mathrm{Na}$ & $75 \%+1$ & $75 \%+1$ & & & \\
\hline Minimum bidding price & $\mathrm{Na}$ & $\begin{array}{c}\text { based on the CNVM } \\
\text { regulation }\end{array}$ & & & & \\
\hline Excepted transactions & & $\begin{array}{l}\text { privatization; bankruptcy; } \\
\text { acquisition of stocks from the } \\
\text { Ministry of Finance. }\end{array}$ & & acquisition of stock & inistry of Finance. & \\
\hline Rival offers & $\mathrm{Na}$ & $\begin{array}{l}\text { a. the rival bid has to be made } \\
\text { at least for the same number } \\
\text { of shares targeted in the first } \\
\text { bid; } \\
\text { b. the price of the rival offer } \\
\text { has to be at least } 5 \% \text { higher } \\
\text { than the price of the first bid; } \\
\text { c. the document of the new } \\
\text { bid has to be filled with the } \\
\text { CNVM within the } 10 \\
\text { transaction days following the } \\
\text { beginning date of the first bid; } \\
\text { d. CNVM decides a single } \\
\text { closing date for all rival bids. }\end{array}$ & & & & \\
\hline $\begin{array}{l}\text { Restrictions on } \\
\text { the bidder's actions }\end{array}$ & & $\begin{array}{l}\text { a. to make a bid within } 20 \\
\text { days after the preliminary } \\
\text { announcement; } \\
\text { b. cannot make any } \\
\text { subsequent offer within the } 12 \\
\text { months after the closing date } \\
\text { of the previous bid. }\end{array}$ & & & & \\
\hline
\end{tabular}




\begin{tabular}{|c|c|c|c|c|c|c|}
\hline & Regime 1 & Regime 2 & Regime 3 & Regime 4 & Regime 5 & Regime 6 \\
\hline Period & 1/01/95-8/04/02 & 9/04/02-4/08/02 & $5 / 08 / 02-24 / 09 / 02$ & $25 / 09 / 02-3 / 10 / 02$ & $4 / 10 / 02-29 / 11 / 02$ & $30 / 11 / 02-8 / 08 / 03$ \\
\hline \multicolumn{7}{|c|}{ PUBLIC TO PRIVATE TRANSACTIONS } \\
\hline $\begin{array}{l}\text { Circumstances } \\
\text { triggering a buyout } \\
\text { transaction }\end{array}$ & $\begin{array}{l}\text { if after the takeover } \\
\text { completion, the target } \\
\text { has less than } 500 \\
\text { shareholders or its } \\
\text { share capital is lower } \\
\text { than } 1 \text { billion ROL }\end{array}$ & \multicolumn{5}{|c|}{$\begin{array}{l}\text { a. the majority shareholder owns at least } 90 \% \text { of the outstanding shares and makes a going private transaction; } \\
\text { b. based on the decision of the General Assembly of Shareholders, if the share capital is lower than } 100.000 \text { euros and there are less than } 100 \text { shareholders. }\end{array}$} \\
\hline $\begin{array}{l}\text { Period for organizing a } \\
\text { buyout transaction }\end{array}$ & $\mathrm{Na}$ & $\begin{array}{l}\text { within } 2 \text { months after the } \\
\text { acquisition of at least } 90 \% \text { of } \\
\text { the outstanding shares }\end{array}$ & \multicolumn{4}{|c|}{ within 12 months after the acquisition of at least $90 \%$ of the outstanding shares } \\
\hline Buyout price & $\begin{array}{l}\text { based on the net assets } \\
\text { value }\end{array}$ & $\begin{array}{l}\text { based on the CNVM } \\
\text { regulation }\end{array}$ & $\begin{array}{l}\text { assessed by an independent } \\
\text { expert that should take into } \\
\text { account the net asset value } \\
\text { and any relevant accounting } \\
\text { information }\end{array}$ & $\begin{array}{l}\text { the maximum of the following } \\
\text { two prices: } \\
\text { (1) the real (inflation-adjusted) } \\
\text { average price paid for } \\
\text { acquiring } 90 \% \text { of the } \\
\text { outstanding shares either from } \\
\text { AVAS or on the stock } \\
\text { exchange. The price will } \\
\text { include the value of any } \\
\text { obligation assigned in the } \\
\text { privatization contract and; } \\
\text { (2) the net asset value based } \\
\text { on IAS }\end{array}$ & $\begin{array}{l}\text { assessed by an independent } \\
\text { expert that should take into } \\
\text { account the net asset value } \\
\text { and any relevant accounting } \\
\text { information }\end{array}$ & $\begin{array}{l}\text { a. the average of at least two } \\
\text { out of the three following } \\
\text { prices: (1) the average market } \\
\text { price over the } 12 \text { months } \\
\text { preceding the offer or before } \\
\text { December } 1 \mathrm{st}, 2002 \text { if the } \\
\text { offeror owns more than } 90 \% \\
\text { on December } 1 \text { st, } 2002 ;(2) \\
\text { the net assets value based on } \\
\text { the IAS and; (3) the highest } \\
\text { price paid by offeror during } \\
\text { the } 12 \text { months preceding the } \\
\text { offer. } \\
\text { b. if none of the three } \\
\text { reference prices mentioned to } \\
\text { a. is available, the biding price } \\
\text { is assessed by an } \\
\text { independent expert based on } \\
\text { IAS. }\end{array}$ \\
\hline $\begin{array}{l}\text { Rights of minority } \\
\text { shareholders }\end{array}$ & $\mathrm{Na}$ & $\mathrm{Na}$ & \multicolumn{3}{|c|}{$\begin{array}{l}\text { the shareholders owning at least } 5 \% \text { of the targeted shares can contest the biding price within } \\
\text { the } 10 \text { days after the report date (at least } 90 \text { days before the biding period) and hire a second } \\
\text { expert to assess a new price }\end{array}$} & $\begin{array}{l}\text { the shareholders owning at } \\
\text { least } 75 \% \text { of the targeted } \\
\text { shares can contest the biding } \\
\text { price within the } 10 \text { days after } \\
\text { the announcement date (at } \\
\text { least } 30 \text { days before the } \\
\text { biding period) and hire a } \\
\text { second expert to assess a } \\
\text { new price }\end{array}$ \\
\hline
\end{tabular}




\begin{tabular}{|c|c|c|c|c|c|c|}
\hline & Regime 1 & Regime 2 & Regime 3 & Regime 4 & Regime 5 & Regime 6 \\
\hline Period & 1/01/95-8/04/02 & 9/04/02-4/08/02 & $5 / 08 / 02-24 / 09 / 02$ & $25 / 09 / 02-3 / 10 / 02$ & $4 / 10 / 02-29 / 11 / 02$ & $30 / 11 / 02-8 / 08 / 03$ \\
\hline $\begin{array}{l}\text { Obligations of minority } \\
\text { shareholders }\end{array}$ & na & $\mathrm{Na}$ & $\mathrm{Na}$ & na & na & na \\
\hline $\begin{array}{l}\text { Resolution of contested } \\
\text { buy-out bids }\end{array}$ & na & $\mathrm{Na}$ & $\begin{array}{l}\text { if the price assessed by the } \\
\text { expert of contesting } \\
\text { shareholders exceeds: } \\
\text { a. by less than } 20 \% \text { the } \\
\text { offeror's price, the bidding } \\
\text { price is equal to the mean of } \\
\text { the two bidding prices } \\
\text { proposed by the two } \\
\text { independent experts } \\
\text { representing the offeror and } \\
\text { contesting shareholders, } \\
\text { respectively; } \\
\text { b. by more than } 20 \% \text { the } \\
\text { offeror's price, the bidding } \\
\text { price will be assessed by a } \\
\text { third expert hired jointly by } \\
\text { offeror and contesting } \\
\text { shareholders }\end{array}$ & $\begin{array}{l}\text { the third expert will try to } \\
\text { conciliate the conclusions of } \\
\text { the two experts hired by } \\
\text { offeror and contesting } \\
\text { shareholders, respectively }\end{array}$ & \multicolumn{2}{|c|}{$\begin{array}{l}\text { if the price assessed by the expert of contesting shareholders } \\
\text { exceeds: } \\
\text { a. by less than } 20 \% \text { the offeror's price, the bidding price is } \\
\text { equal to the mean of the two bidding prices proposed by the } \\
\text { two independent experts representing the offeror and } \\
\text { contesting shareholders, respectively; } \\
\text { b. by more than } 20 \% \text { the offeror's price, the bidding price will } \\
\text { be assessed by a third expert hired jointly by offeror and } \\
\text { contesting shareholders }\end{array}$} \\
\hline Remarks & $\begin{array}{l}\text { the offeror aiming to } \\
\text { acquire a controlling } \\
\text { position ( } 33 \%+1 \text { share) } \\
\text { without exceeding the } \\
\text { majority position } \\
(50 \%+1) \text { is allowed to } \\
\text { make a partial bid and } \\
\text { to allocate pro-rata the } \\
\text { tendered shares in the } \\
\text { case the offer is } \\
\text { oversubscribed }\end{array}$ & & $\begin{array}{l}\text { the obligation to buy-out the } \\
\text { minority shareholders does } \\
\text { not concern the Government } \\
\text { owning at least } 90 \% \text { of the } \\
\text { outstanding shares of a public } \\
\text { company }\end{array}$ & & $\begin{array}{l}\text { the obligation to buy-out the } \\
\text { minority shareholders does } \\
\text { not concern the Government } \\
\text { owning at least } 90 \% \text { of the } \\
\text { outstanding shares of a public } \\
\text { company }\end{array}$ & $\begin{array}{l}\text { the obligation to buy-out the } \\
\text { minority shareholders does } \\
\text { not concern the Government } \\
\text { owning at least } 90 \% \text { of the } \\
\text { outstanding shares of a public } \\
\text { company } \\
\text { more details about the } \\
\text { independent experts and } \\
\text { publicity of the bid are } \\
\text { provided in Instruction no } \\
\text { 2/December } 2002\end{array}$ \\
\hline
\end{tabular}




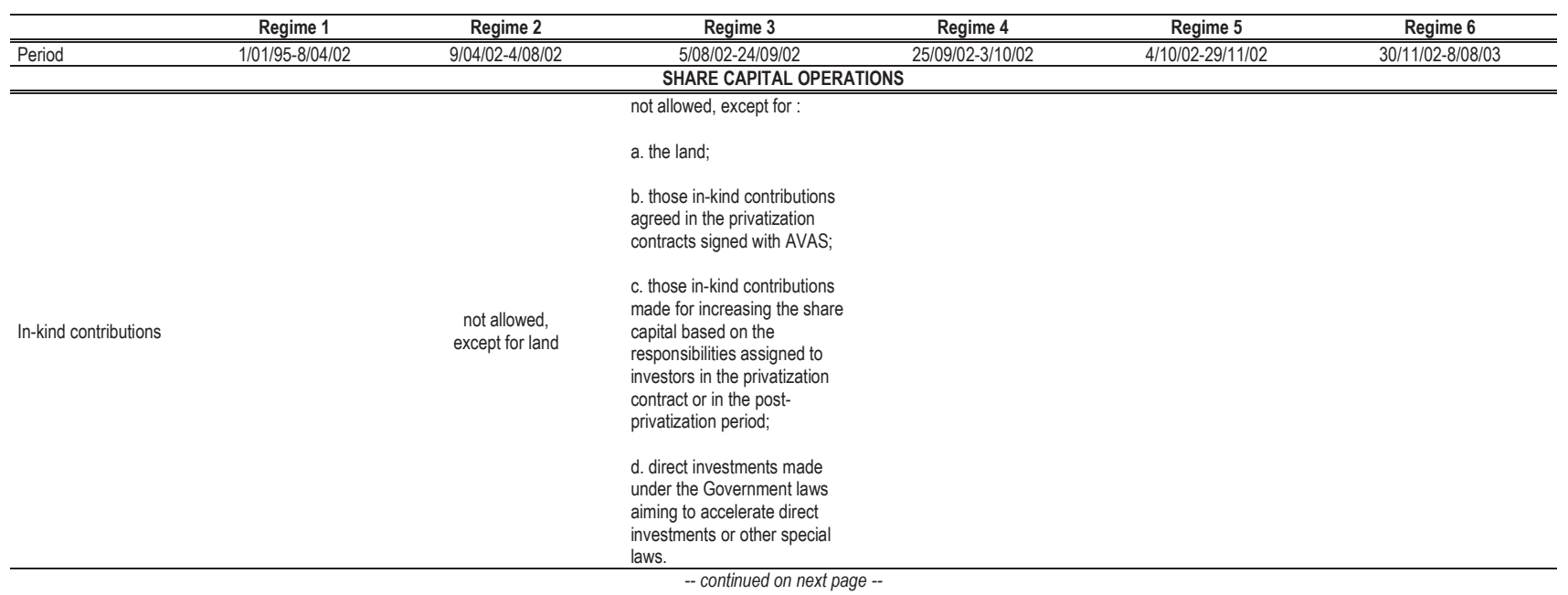




\begin{tabular}{|c|c|c|c|c|c|c|}
\hline & Regime 1 & Regime 2 & Regime 3 & Regime 4 & Regime 5 & Regime 6 \\
\hline Period & $1 / 01 / 95-8 / 04 / 02$ & $\begin{array}{l}9 / 04 / 02-4 / 08 / 02 \\
\end{array}$ & 5/08/02-24/09/02 & "25/09/02-3/10/02 & 4/10/02-29/11/02 & $30 / 11 / 02-8 / 08 / 03$ \\
\hline $\begin{array}{l}\text { Preemptive rights / } \\
\text { Approval rights }\end{array}$ & & $\begin{array}{l}\text { a. the preemptive rights can } \\
\text { not be canceled by the } \\
\text { decision of the General } \\
\text { Meeting of Shareholders; } \\
\text { b. the preemptive rights can } \\
\text { be tradable on the market; } \\
\text { c. the subscribing price } \\
\text { includes a premium equal to } \\
\text { the inflation achieved over the } \\
\text { period starting with the date of } \\
\text { the previous equity issue and } \\
\text { should be paid only in cash. } \\
\text { The premium will be moved } \\
\text { into the Reserve account that } \\
\text { should be capitalized within } \\
\text { the next } 6 \text { months by } \\
\text { increasing the face value of } \\
\text { shares for all shareholders. } \\
\text { d. if the inflation rate exceeds } \\
20 \% \text { over the period starting } \\
\text { with the date of the previous } \\
\text { reassessment, the assets } \\
\text { should be reassessed before } \\
\text { accounting for any } \\
\text { contribution; the up-dated } \\
\text { price should take into account } \\
\text { the market value of the } \\
\text { assets. }\end{array}$ & $\begin{array}{l}\text { a. the issuing price includes a } \\
\text { premium equal to the } \\
\text { difference between the net } \\
\text { asset value and the face value } \\
\text { of the shares; } \\
\text { b. the assets should be } \\
\text { reassessed before the } \\
\text { capitalization of any } \\
\text { contribution by taking into } \\
\text { account the discounted value } \\
\text { of fixed assets and the } \\
\text { inflation rate over the period } \\
\text { between the date of the last } \\
\text { apprise and the date of the } \\
\text { General Meeting of } \\
\text { Shareholders, as well as the } \\
\text { market value of those assets } \\
\text { (goods). }\end{array}$ & & & \\
\hline
\end{tabular}


Appendix 1B: Overview of regulatory regimes - Part II: August 2003 - December 2012

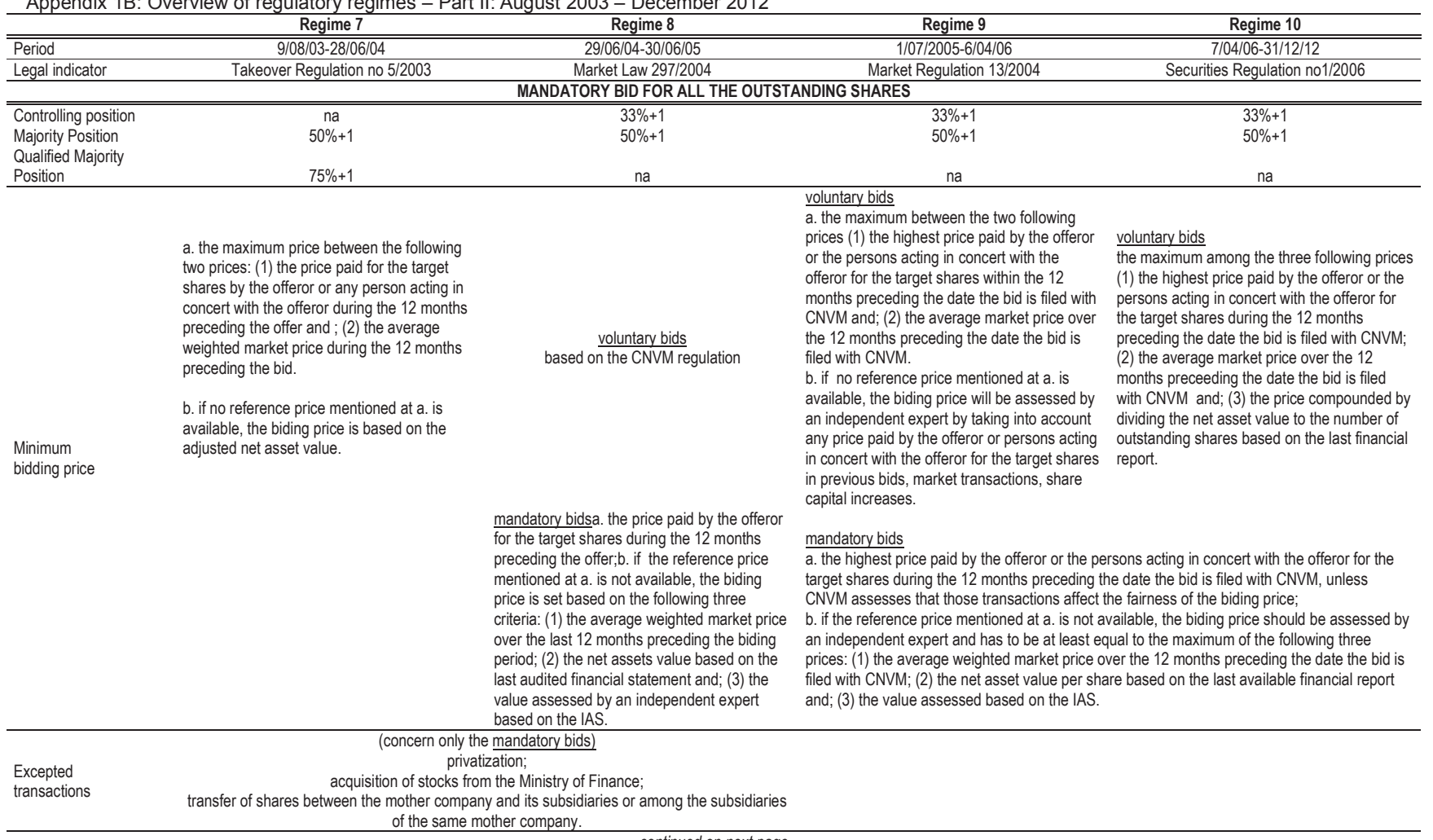

-- continued on next page -- 


\begin{tabular}{|c|c|c|c|c|}
\hline & Regime 7 & Regime 8 & Regime 9 & Regime 10 \\
\hline Period & 9/08/03-28/06/04 & $29 / 06 / 04-30 / 06 / 05$ & $1 / 07 / 2005-6 / 04 / 06$ & $=7 / 04 / 06-31 / 12 / 12$ \\
\hline \multirow{5}{*}{ Rival offers } & \multirow{5}{*}{$\begin{array}{l}\text { a. the rival bid has to be made at least for the } \\
\text { same threshold targeted in the first bid; } \\
\text { b. the document of the rival bid has to be filled } \\
\text { with the CNVM within the } 10 \text { transaction days } \\
\text { following the announcement date of the initial } \\
\text { bid; } \\
\text { c. CNVM decides a single closing date for all } \\
\text { rival bids. }\end{array}$} & & $\begin{array}{l}\text { a. the rival bid has to be made at least for the } \\
\text { same number of shares and threshold } \\
\text { targeted in the first bid; }\end{array}$ & $\begin{array}{l}\text { a. the rival bid has to be made at least for the } \\
\text { same number of shares and threshold } \\
\text { targeted in the first bid; }\end{array}$ \\
\hline & & $\begin{array}{l}\text { a. the rival bid has to be made at least for the } \\
\text { same number of shares and threshold } \\
\text { targeted in the first bid; }\end{array}$ & $\begin{array}{l}\text { b. the price of the rival offer to be at least } 5 \% \\
\text { higher than the price of the first bid; }\end{array}$ & $\begin{array}{l}\text { b. the price of the rival offer to be at least } 5 \% \\
\text { higher than the price of the first bid; }\end{array}$ \\
\hline & & \multirow{3}{*}{$\begin{array}{l}\text { b. the price of the rival offer to be at least } 5 \% \\
\text { higher than the price of the first bid; } \\
\text { c. the document of the rival bid has to be filled } \\
\text { with the CNVM within the } 10 \text { transaction days } \\
\text { following the announcement date of the initial } \\
\text { bid; } \\
\text { d. CNVM decides a single closing date for all } \\
\text { rival bids but not later than } 60 \text { trading days } \\
\text { after the first day of the bid period. }\end{array}$} & $\begin{array}{l}\text { c. the document of the rival bid has to be filled } \\
\text { with the CNVM within the } 10 \text { transaction days } \\
\text { following the announcement date of the initial } \\
\text { mandatory bid or preliminary annoucement } \\
\text { date of the voluntary bid; }\end{array}$ & $\begin{array}{l}\text { c. the document of the rival bid has to be filled } \\
\text { with the CNVM within the } 10 \text { transaction days } \\
\text { following the announcement date of the initial } \\
\text { mandatory bid or preliminary annoucement } \\
\text { date of the voluntary bid; }\end{array}$ \\
\hline & & & $\begin{array}{l}\text { d. CNVM decides a single closing date for all } \\
\text { rival bids and the deadlines for biding price } \\
\text { amendments; }\end{array}$ & $\begin{array}{l}\text { d. CNVM decides a single closing date for all } \\
\text { rival bids and the delays to make price } \\
\text { amendments; }\end{array}$ \\
\hline & & & $\begin{array}{l}\text { e. the final biding price is determined by } \\
\text { auctions among the rival bidders. The bidder } \\
\text { offering the highest price gain the auction } \\
\text { while all the other bids are canceled by } \\
\text { CNVM. }\end{array}$ & $\begin{array}{l}\text { e. the final biding price is determined by } \\
\text { auctions among the rival bidders. The bidder } \\
\text { offering the highest price gain the auction } \\
\text { while all the other bids are canceled by } \\
\text { CNVM. }\end{array}$ \\
\hline $\begin{array}{l}\text { Restrictions on } \\
\text { the bidder's actions }\end{array}$ & $\begin{array}{l}\text { the offeror and the persons acting in concert } \\
\text { with the offeror can no longer make any } \\
\text { transaction with that target shares outside the } \\
\text { scope of the bid }\end{array}$ & $\begin{array}{l}\text { the offeror or the persons acting in concert } \\
\text { with the offeror cannot make any subsequent } \\
\text { bid for the same target during } 12 \text { months after } \\
\text { the closing of a voluntary bid }\end{array}$ & $\begin{array}{l}\text { the transactions made by offeror with the } \\
\text { target stocks outside the bid have to be } \\
\text { concluded at a price higher than the bidding } \\
\text { price and no later than } 8 \text { days before the end } \\
\text { of the bidding period }\end{array}$ & $\begin{array}{l}\text { a. the transactions made by offeror with the } \\
\text { target stocks outside the bid have to be } \\
\text { concluded at a price higher than the bidding } \\
\text { price and no later than } 8 \text { days before the end } \\
\text { of the bidding period } \\
\text { b. if such outside transactions are concluded } \\
\text { during the biding period, the offeror has to } \\
\text { increase the biding price to be at least as high } \\
\text { as the highest transaction price paid by the } \\
\text { offeror }\end{array}$ \\
\hline
\end{tabular}




\begin{tabular}{|c|c|c|c|c|}
\hline & Regime 7 & Regime 8 & Regime 9 & Regime 10 \\
\hline Period & 9/08/03-28/06/04 & $29 / 06 / 04-30 / 06 / 05$ & 1/07/2005-6/04/06 & $7 / 04 / 06-31 / 12 / 12$ \\
\hline \multicolumn{5}{|c|}{ PUBLIC TO PRIVATE TRANSACTIONS } \\
\hline \multirow{3}{*}{$\begin{array}{l}\text { Circumstances } \\
\text { triggering a buyout } \\
\text { transaction }\end{array}$} & \multirow{3}{*}{$\begin{array}{l}\text { mandatory delisting when the majority } \\
\text { shareholder owns more than } 90 \% \text { of the } \\
\text { outstanding shares }\end{array}$} & $\begin{array}{l}\text { following a takeover bid for all outstanding } \\
\text { shares, a shareholder has a squeeze out right } \\
\text { if : }\end{array}$ & $\begin{array}{l}\text { following a takeover bid, a shareholder has a } \\
\text { squeeze-out right if: }\end{array}$ & $\begin{array}{l}\text { following a takeover bid, a shareholder has a } \\
\text { squeeze-out right if: }\end{array}$ \\
\hline & & $\begin{array}{l}\text { a. he owns at least } 95 \% \text { of the outstanding } \\
\text { shares of target; }\end{array}$ & $\begin{array}{l}\text { a. he owns at least } 95 \% \text { of outstanding shares } \\
\text { of the target; }\end{array}$ & $\begin{array}{l}\text { a. he owns at least } 95 \% \text { of outstanding shares } \\
\text { of the target; }\end{array}$ \\
\hline & & $\begin{array}{l}\text { b. at least } 90 \% \text { of the targeted shares have } \\
\text { been tendered. }\end{array}$ & $\begin{array}{l}\text { b. at least } 90 \% \text { of targeted shares have been } \\
\text { tendered. }\end{array}$ & $\begin{array}{l}\text { b. at least } 90 \% \text { of targeted shares have been } \\
\text { tendered. }\end{array}$ \\
\hline $\begin{array}{l}\text { Period for organizing a } \\
\text { buyout transaction }\end{array}$ & $\begin{array}{l}\text { within } 12 \text { months after the acquisition of at } \\
\text { least } 90 \% \text { of the outstanding shares }\end{array}$ & ( & na & na \\
\hline \multirow[t]{2}{*}{ Buyout price } & \multirow{2}{*}{$\begin{array}{l}\text { assessed by an independent expert and has } \\
\text { to be at least equal to the average price of the } \\
\text { following three prices: (1) the average market } \\
\text { price over the } 12 \text { months preceding the offer; } \\
\text { (2) the net assets value based on the IAS and; } \\
\text { (3) the highest price paid by the offeror during } \\
\text { the } 12 \text { months preceding the offer. The expert } \\
\text { should take into account all prices paid by } \\
\text { offeror for the target shares (market } \\
\text { transactions, previous public offers, capital } \\
\text { increases) during the } 12 \text { months preceding the } \\
\text { offer. }\end{array}$} & $\begin{array}{l}\text { a. fair price standard: the biding price paid in a } \\
\text { previous mandatory bid or voluntary bid when } \\
\text { at least } 90 \% \text { of the targeted shares were } \\
\text { tendered, if the offeror makes use of its } \\
\text { squeeze-out right within the } 3 \text { months } \\
\text { following the closing of the previous takeover } \\
\text { bid. }\end{array}$ & $\begin{array}{l}\text { a. fair price standard: the biding price of the } \\
\text { previous voluntary or mandatory takeover bid } \\
\text { where at least } 90 \% \text { of the targeted shares } \\
\text { were tendered, if the offeror makes use of its } \\
\text { squeeze-out right within the } 3 \text { months } \\
\text { following the closing of the previous takeover } \\
\text { bid. }\end{array}$ & \multirow{2}{*}{$\begin{array}{l}\text { a. fair price standard: the price accepted in the } \\
\text { previous voluntary or mandatory bid made for } \\
\text { all outstanding shares where at least of } 90 \% \\
\text { of the target outstanding shares and } 90 \% \text { of } \\
\text { the voting rights were tendered. } \\
\text { b. in all other circumstances, the fair price will } \\
\text { be established by an independent expert } \\
\text { based on IAS }\end{array}$} \\
\hline & & $\begin{array}{l}\text { b. if the squeeze-out right is not enforced } \\
\text { within the } 3 \text { months following the closing of the } \\
\text { previous bid, the fair price will be established } \\
\text { by an independent expert based on IAS. }\end{array}$ & $\begin{array}{l}\text { b. in all other circumstances, the fair price will } \\
\text { be established by an independent expert } \\
\text { based on IAS }\end{array}$ & \\
\hline $\begin{array}{l}\text { Rights of } \\
\text { minority shareholders }\end{array}$ & $\begin{array}{l}\text { the shareholders owning at least } 75 \% \text { of the } \\
\text { targeted shares can contest the biding price } \\
\text { within the } 10 \text { days after the announcement } \\
\text { date (at least } 30 \text { days before the biding period) } \\
\text { and hire a second expert to assess a new } \\
\text { price }\end{array}$ & $\begin{array}{l}\text { the right to ask the majority shareholder } \\
\text { owning at least } 95 \% \text { of the outstanding shares } \\
\text { of target to buy-out the remaining shares at } \\
\text { the fair price }\end{array}$ & $\begin{array}{l}\text { the individual right to ask the majority } \\
\text { shareholder owning at least } 95 \% \text { of the total } \\
\text { shares of the company to buy-out the } \\
\text { remaining shares at a fair price }\end{array}$ & $\begin{array}{l}\text { the individual right to ask the majority } \\
\text { shareholder owning at least } 95 \% \text { of the total } \\
\text { shares of the company to buy-out the } \\
\text { remaining shares at a fair price }\end{array}$ \\
\hline $\begin{array}{l}\text { Obligations } \\
\text { of minority shareholders }\end{array}$ & ( & na & \multicolumn{2}{|c|}{$\begin{array}{l}\text { the minority shareholders has the explicit obligation to sell their shares to a major shareholder } \\
\text { having a squeeze-out right }\end{array}$} \\
\hline $\begin{array}{l}\text { Resolution of contested } \\
\text { buy-out bids }\end{array}$ & na & na & o & ( \\
\hline
\end{tabular}




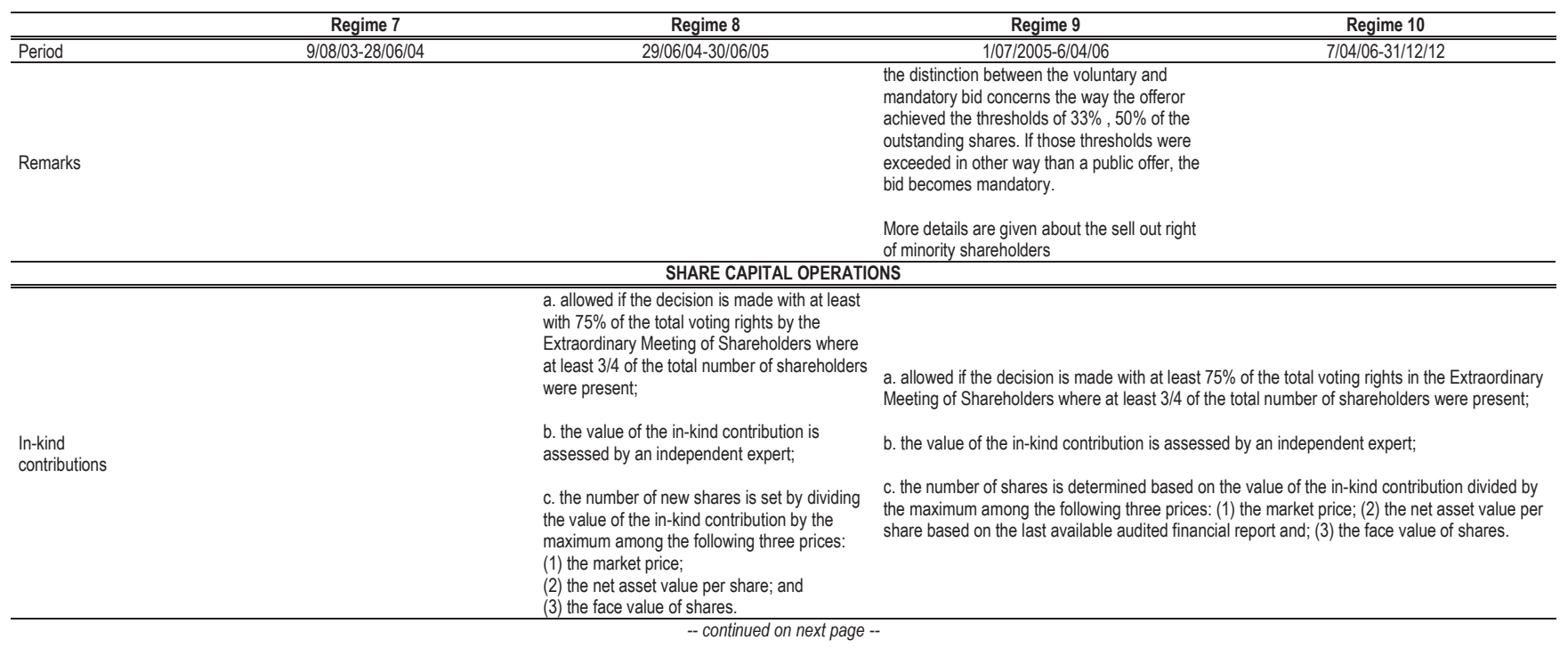




\begin{tabular}{|c|c|c|c|c|}
\hline & Regime 7 & Regime 8 & Regime 9 & Regime 10 \\
\hline Period & 9/08/03-28/06/04 & $29 / 06 / 04-30 / 06 / 05$ & $1 / 07 / 2005-6 / 04 / 06$ & $7 / 04 / 06-31 / 12 / 12$ \\
\hline \multirow{4}{*}{$\begin{array}{l}\text { Preemptive rights } \\
\text { /Approval rights }\end{array}$} & & $\begin{array}{l}\text { in the case of capital increase by cash } \\
\text { contribution the Extraordinary Assembly of } \\
\text { Shareholders may decide to cancel the } \\
\text { preemptive rights of shareholders if at least } \\
3 / 4 \text { of the number of shareholders are present } \\
\text { at the meeting and with the votes } \\
\text { representing at least } 75 \% \text { of the total voting } \\
\text { rights }\end{array}$ & \multicolumn{2}{|c|}{$\begin{array}{l}\text { Extraordinary Meeting of Shareholders may decide to cancel the preemptive rights of } \\
\text { shareholders if at least } 3 / 4 \text { of the number of shareholders are present at the meeting and with } \\
\text { the votes representing at least } 75 \% \text { of the total voting rights }\end{array}$} \\
\hline & & & \multirow{3}{*}{$\begin{array}{l}\text { a. the shares issued but unsubscribed by the } \\
\text { existing shareholders can be offered to the } \\
\text { outside investors at a price higher than that } \\
\text { proposed to existing shareholders during the } \\
\text { subscription period, unless the Extraordinary } \\
\text { Meeting of Shareholders decides to cancel the } \\
\text { unsubscribed shares; } \\
\text { b. the Extraordinary Assembly of Shareholders } \\
\text { approves whether the preemptive rights are } \\
\text { tradable on the stock market; } \\
\text { c. if the Board of Directors is mandated, it can } \\
\text { substitute to the Extraordinary Meeting of } \\
\text { Shareholders to make any decision in } \\
\text { connection with equity issues; } \\
\text { d. the number of shares issued in the case of } \\
\text { a cash contribution when the preemptive rights } \\
\text { of shareholders were cancelled is determined } \\
\text { by the Board of Directors by dividing the value } \\
\text { of the contribution to the maximum among the } \\
\text { following three prices: (1) the average market } \\
\text { price over } 12 \text { months before the date of the } \\
\text { EMS; (2) the net asset value based on the last } \\
\text { available audited financial report and; (3) the } \\
\text { face value of shares. }\end{array}$} & $\begin{array}{l}\text { a. the shares issued but unsubscribed by the } \\
\text { existing shareholders can be offered to the } \\
\text { outside investors at a price higher than that } \\
\text { proposed to existing shareholders during the } \\
\text { subscription period, unless the Extraordinary } \\
\text { Meeting of Shareholders decides to cancel the } \\
\text { unsubscribed shares; }\end{array}$ \\
\hline & & & & $\begin{array}{l}\text { b. the Extraordinary Assembly of Shareholders } \\
\text { approves whether the preemptive rights are } \\
\text { tradable on the stock market; }\end{array}$ \\
\hline & & & & $\begin{array}{l}\text { c. if the Board of Directors is mandated, it can } \\
\text { substitute to the Extraordinary Assembly of } \\
\text { Shareholders to make any decision in } \\
\text { connection with equity issues. }\end{array}$ \\
\hline
\end{tabular}


Appendix 2: Definition of variables

\begin{tabular}{|c|c|}
\hline \multicolumn{2}{|l|}{ Dependent variables } \\
\hline Initial bid premium & $\begin{array}{l}\left(p_{\text {initial }}-p_{-35}\right) / p_{-35} \text {, where } p_{\text {initial }} \text { is the initial offer price and } p_{-35} \text { is the closing price on day } 35 \text { before the CNVM approves the takeover } \\
\text { document }\end{array}$ \\
\hline Final bid premium & $\begin{array}{l}\left(p_{\text {final }}-p_{-35}\right) / p_{-35}, \text { where } p_{\text {initial }} \text { is the final offer price and } p_{-35} \text { is the closing price on day } 35 \text { before the CNVM approves the takeover } \\
\text { document }\end{array}$ \\
\hline Bid outcome & $\begin{array}{l}\text { the ratio of the number of tendered shares by the number of target shares that the acquirer wants to acquire according to the } \\
\text { takeover document }\end{array}$ \\
\hline \multicolumn{2}{|l|}{ Independent variables } \\
\hline \multicolumn{2}{|c|}{ Corporate governance attributes of the target } \\
\hline Financial dilution & $\begin{array}{l}1-\left(100-d_{1}\right) \cdot\left(100-d_{2}\right) \ldots \cdot\left(100-d_{k}\right) / 100^{k} \text { where } k \text { is the number of equity changes before the bid date and } d_{k} \text { is the financial dilution per } \\
\text { equity change } \\
d_{k}=\left(\text { free float ex-post } t_{k} \text { - free float ex ante }\right)^{*} 100 / \text { free float ex ante } k\end{array}$ \\
\hline Equity change & the number of equity changes before the bid date \\
\hline \multicolumn{2}{|c|}{ Ownership attributes of the target } \\
\hline Direct toehold & the stake in the target's equity owned by the acquirer at the bid date \\
\hline Indirect toehold & the stake in the target's equity owned by the acquirer and the persons acting in concert with the acquirer at the bid date \\
\hline Zero toehold & an indicator variable that takes the value of 1 if the bidder owns no target share at the bid date and 0 otherwise. \\
\hline Direct toehold $\in(0 ; 33 \%)$ & $\begin{array}{l}\text { an indicator variable that takes the value of } 1 \text { if the bidder has an initial positive stake lower than } 33 \% \text { of the target's equity capital } \\
\text { and } 0 \text { otherwise. }\end{array}$ \\
\hline Direct toehold $\in[33 \% ; 50 \%)$ & $\begin{array}{l}\text { an indicator variable that takes the value of } 1 \text { if the bidder has an initial positive stake comprised between } 33 \% \text { and } 50 \% \text { of the } \\
\text { target's equity capital and } 0 \text { otherwise. }\end{array}$ \\
\hline Direct toehold $\in[50 \% ; 90 \%)$ & $\begin{array}{l}\text { an indicator variable that takes the value of } 1 \text { if the bidder has an initial positive stake comprised between } 50 \% \text { and } 90 \% \text { of the } \\
\text { target's equity capital and } 0 \text { otherwise. }\end{array}$ \\
\hline Direct toehold $\in[90 \% ; 100 \%)$ & $\begin{array}{l}\text { an indicator variable that takes the value of } 1 \text { if the bidder has an initial positive stake higher than } 90 \% \text { of the target's equity capital } \\
\text { and } 0 \text { otherwise. }\end{array}$ \\
\hline Indirect toehold $\in(0 ; 33 \%)$ & $\begin{array}{l}\text { an indicator variable that takes the value of } 1 \text { if the bidder and the persons acting in concert with the acquirer have an initial positive } \\
\text { stake lower than } 33 \% \text { of the target's equity capital and } 0 \text { otherwise. }\end{array}$ \\
\hline Indirect toehold $\in[33 \% ; 50 \%)$ & $\begin{array}{l}\text { an indicator variable that takes the value of } 1 \text { if the bidder and the persons acting in concert with the acquirer have an initial positive } \\
\text { stake comprised between } 33 \% \text { and } 50 \% \text { of the target's equity capital and } 0 \text { otherwise }\end{array}$ \\
\hline Indirect toehold $\in[50 \% ; 90 \%)$ & $\begin{array}{l}\text { an indicator variable that takes the value of } 1 \text { if the bidder and the persons acting in concert with the acquirer have an initial positive } \\
\text { stake comprised between } 50 \% \text { and } 90 \% \text { of the target's equity capital and } 0 \text { otherwise }\end{array}$ \\
\hline Indirect toehold $\in[90 \% ; 100 \%)$ & $\begin{array}{l}\text { an indicator variable that takes the value of } 1 \text { if the bidder and the persons acting in concert with the acquirer have an initial positive } \\
\text { stake higher than } 90 \% \text { of the target's equity capital and } 0 \text { otherwise }\end{array}$ \\
\hline AVAS foothold & an indicator variable that takes the value of 1 if the bidder bought a stake from the Privatization authority before the bid date \\
\hline
\end{tabular}


Novel control

Other insiders
Short-term toehold

\section{Offer variables}

Rival

Bid jump

Period revision an indicator variable that takes the value of 1 if the bidder had less than $50 \%$ of target outstanding shares before the bid and more than $50 \%$ of target outstanding shares afterwards

the ratio of the net purchase position of the bidder by the outstanding shares of target

an indicator variable that takes the value of 1 if the insiders, other than the bidder had a selling net position during the 12 months preceding the bid and 0 otherwise

an indicator variable that takes the value of 1 if a rival offer was made before the closing date and 0 otherwise the percentage change from the initial offer price to the final offer price an indicator variable that takes the value of 1 if the bid period was extended at least once and 0 otherwise

\section{Stock Market, Control Benchmarks and Regulatory Environment}

52-week High

the ratio of the bidding price and the highest market price during the 12 months preceding the bid

Bidder paid 52-week High

an indicator variable that takes the value of 1 if the 52-week High is equal the highest price paid by the bidder during the 12 months preceding the bid

Privatization premium benchmark the moving average of the privatization premiums clustered by industry and matched to each target based on the industrial sector

Regulatory regime an indicator variable that takes the value of 1 if the bid is approved within the regulatory regime

Bidder characteristics

Individual investor

Joint stock company

Limited liability company

Foreign company

Financial investor

Group

SIF

an indicator variable that takes the value of 1 if the bidder is an individual investor and 0 otherwise

an indicator variable that takes the value of 1 if the bidder is a domestic joint stock company and 0 otherwise

an indicator variable that takes the value of 1 if the bidder is a domestic limited liability company and 0 otherwise

an indicator variable that takes the value of 1 if the bidder is a domestic limited liability foreign company and 0 otherwise an indicator variable that takes the value of 1 if the bidder is a financial invetsor and 0 otherwise

an indicator variable that takes the value of 1 if the takeover is made by group of more than two bidders and 0 otherwise

an indicator variable that takes the value of 1 if the bidder is one of the 5 Romanian private investment companies founded by political decision during the Mass privatization and 0 otherwise 
Figure 1: Bid outcome kernel density estimate

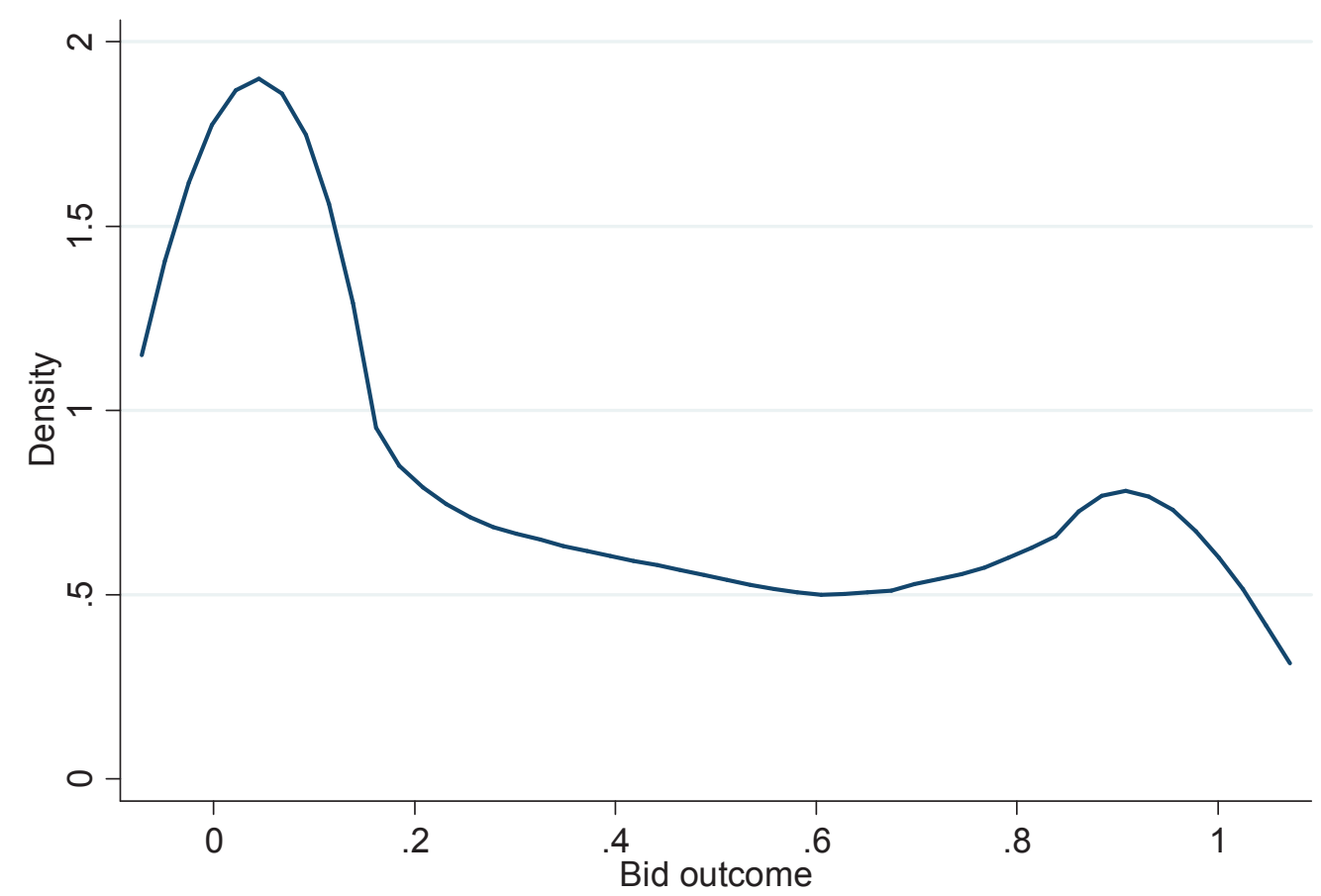

kernel $=$ epanechnikov, bandwidth $=0.0713$ 
Table 1: Descriptive statistics on the main variables

\begin{tabular}{|c|c|c|c|c|c|c|c|c|}
\hline Variable name & $\mathrm{N}$ & Mean & Std. dev. & Min & Q1 & Median & Q3 & Max \\
\hline \multicolumn{9}{|l|}{ Continuous variables } \\
\hline Bid outcome $(\%)$ & 1,814 & 36.34 & 35.54 & 0.00 & 1.72 & 24.89 & 69.67 & 100.00 \\
\hline Initial bid premium & 1,733 & 124.09 & 237.73 & -98.28 & 0.00 & 27.66 & 119.18 & 900.00 \\
\hline Final bid premium & 1,733 & 180.54 & 329.79 & -98.28 & 1.63 & 43.26 & 180.00 & $1,263.13$ \\
\hline Tendered block & 1,814 & 15.95 & 22.74 & 0.00 & 0.19 & 4.26 & 23.77 & 99.77 \\
\hline Bid jump & 323 & 3.23 & 4.88 & 0.00 & 1.20 & 1.76 & 3.38 & 50.00 \\
\hline Bid length & 1,854 & 27.62 & 18.27 & 0.00 & 20.00 & 21.00 & 30.00 & 324.00 \\
\hline 52-week high & 1,757 & 149.17 & 169.01 & 0.06 & 65.33 & 100.00 & 133.33 & 714.29 \\
\hline $\begin{array}{l}\text { Privatization premium } \\
\text { benchmark }\end{array}$ & 1,853 & 356.49 & 247.03 & -87.99 & 182.61 & 350.89 & 529.39 & $1,737.50$ \\
\hline AVAS foothold & 402 & 58.31 & 22.49 & 2.09 & 40.00 & 51.00 & 72.33 & 99.57 \\
\hline \# equity changes & 1,854 & 1.05 & 1.39 & 0.00 & 0.00 & 1.00 & 2.00 & 11.00 \\
\hline Financial dilution & 1,854 & -0.13 & 0.26 & -1.00 & -0.09 & 0.00 & 0.00 & 0.75 \\
\hline \multicolumn{9}{|l|}{ Dummy variables } \\
\hline Price revision & 1,854 & $17.00 \%$ & & & & & & \\
\hline Period extended & 1,702 & $21.00 \%$ & & & & & & \\
\hline Bidder AVAS & 1,854 & $12.00 \%$ & & & & & & \\
\hline Equity change & 1,854 & $55.00 \%$ & & & & & & \\
\hline Rival & 1,854 & $9.00 \%$ & & & & & & \\
\hline Individual investor & 1,854 & $29.00 \%$ & & & & & & \\
\hline Joint stock company & 1,854 & $20.00 \%$ & & & & & & \\
\hline Limited liability company & 1,854 & $29.00 \%$ & & & & & & \\
\hline Foreign company & 1,854 & $11.00 \%$ & & & & & & \\
\hline Financial investor & 1,854 & $6.00 \%$ & & & & & & \\
\hline Group & 1,854 & $2.00 \%$ & & & & & & \\
\hline SIF & 1,854 & $3.00 \%$ & & & & & & \\
\hline Regulatory regime 1 & 1,854 & $47.00 \%$ & & & & & & \\
\hline Regulatory regime 2 & 1,854 & $3.00 \%$ & & & & & & \\
\hline Regulatory regime 3 & 1,854 & $1.00 \%$ & & & & & & \\
\hline Regulatory regime 4 & 1,854 & $0.01 \%$ & & & & & & \\
\hline Regulatory regime 5 & 1,854 & $2.00 \%$ & & & & & & \\
\hline Regulatory regime 6 & 1,854 & $7.00 \%$ & & & & & & \\
\hline Regulatory regime 7 & 1,854 & $16.00 \%$ & & & & & & \\
\hline Regulatory regime 8 & 1,854 & $7.00 \%$ & & & & & & \\
\hline Regulatory regime 9 & 1,854 & $3.00 \%$ & & & & & & \\
\hline Regulatory regime 10 & 1,854 & $14.00 \%$ & & & & & & \\
\hline
\end{tabular}


Table 2: Acquisition premiums and bid outcome by year

\begin{tabular}{|c|c|c|c|c|c|c|c|c|}
\hline Year & $\mathrm{N}$ & Mean & St. dev. & Min & Q1 & Median & Q2 & Max \\
\hline \multicolumn{9}{|c|}{ Panel A: Initial bid premium (\%) } \\
\hline 1998 & 139 & 135.69 & 244.91 & -97.97 & 16.28 & 38.46 & 135.29 & 900.00 \\
\hline 1999 & 144 & 107.49 & 195.99 & -88.00 & 0.00 & 33.33 & 118.13 & 900.00 \\
\hline 2000 & 204 & 103.76 & 218.49 & -96.00 & -1.61 & 25.69 & 108.33 & 900.00 \\
\hline 2001 & 257 & 126.67 & 241.15 & -98.00 & 0.00 & 25.00 & 150.00 & 900.00 \\
\hline 2002 & 165 & 89.46 & 185.19 & -86.00 & 0.00 & 23.53 & 88.89 & 900.00 \\
\hline 2003 & 220 & 123.19 & 238.38 & -98.28 & 0.00 & 25.00 & 95.24 & 900.00 \\
\hline 2004 & 252 & 197.68 & 308.60 & -90.77 & 0.00 & 45.64 & 253.08 & 900.00 \\
\hline 2005 & 69 & 125.50 & 252.42 & -49.25 & 0.00 & 23.62 & 121.61 & 900.00 \\
\hline 2006 & 68 & 93.30 & 188.85 & -74.40 & 0.00 & 25.75 & 100.00 & 900.00 \\
\hline 2007 & 67 & 87.18 & 164.52 & -85.71 & -0.00 & 8.82 & 154.03 & 658.06 \\
\hline 2008 & 47 & 97.94 & 237.40 & -36.87 & 0.00 & 11.02 & 66.67 & 900.00 \\
\hline 2009 & 25 & 58.98 & 120.21 & -79.63 & 0.00 & 20.00 & 63.33 & 535.14 \\
\hline 2010 & 35 & 147.87 & 259.95 & -36.28 & 2.38 & 20.34 & 131.28 & 900.00 \\
\hline 2011 & 24 & 129.44 & 257.54 & -77.32 & 1.95 & 29.39 & 145.80 & 900.00 \\
\hline 2012 & 17 & 6.48 & 47.45 & -56.00 & -16.25 & 0.00 & 13.03 & 140.00 \\
\hline Total & 1,733 & 124.09 & 237.73 & -98.28 & 0.00 & 27.66 & 119.18 & 900.00 \\
\hline \multicolumn{9}{|c|}{ Panel B: Final bid premium (\%) } \\
\hline 1998 & 139 & 154.72 & 294.04 & -96.67 & 16.67 & 38.89 & 150.00 & $1,263.13$ \\
\hline 1999 & 144 & 139.37 & 260.92 & -88.00 & 2.67 & 37.72 & 143.42 & $1,263.13$ \\
\hline 2000 & 204 & 198.58 & 347.39 & -90.00 & 6.00 & 58.17 & 231.01 & $1,263.13$ \\
\hline 2001 & 257 & 206.21 & 354.82 & -98.00 & 0.00 & 55.00 & 240.80 & $1,263.13$ \\
\hline 2002 & 165 & 171.14 & 310.07 & -86.00 & 5.88 & 50.00 & 187.36 & $1,263.13$ \\
\hline 2003 & 220 & 169.44 & 312.95 & -98.28 & 5.34 & 42.16 & 171.66 & $1,263.13$ \\
\hline 2004 & 252 & 262.42 & 402.01 & -90.77 & 5.00 & 66.67 & 318.87 & $1,263.13$ \\
\hline 2005 & 69 & 189.77 & 360.67 & -49.25 & 0.00 & 42.86 & 150.00 & $1,263.13$ \\
\hline 2006 & 68 & 126.13 & 276.37 & -74.40 & 0.00 & 28.25 & 112.33 & $1,263.13$ \\
\hline 2007 & 67 & 119.31 & 244.40 & -85.71 & 0.00 & 9.41 & 168.33 & $1,263.13$ \\
\hline 2008 & 47 & 116.02 & 301.17 & -36.87 & 0.00 & 11.11 & 66.67 & $1,263.13$ \\
\hline 2009 & 25 & 61.86 & 125.30 & -79.63 & 0.00 & 20.00 & 63.33 & 535.14 \\
\hline 2010 & 35 & 158.29 & 295.63 & -36.28 & 2.38 & 20.34 & 131.28 & $1,263.13$ \\
\hline 2011 & 24 & 159.70 & 354.26 & -77.32 & 1.95 & 29.39 & 145.80 & $1,263.13$ \\
\hline 2012 & 17 & 6.48 & 47.45 & -56.00 & -16.25 & 0.00 & 13.03 & 140.00 \\
\hline Total & 1,733 & 180.54 & 329.79 & -98.28 & 1.63 & 43.26 & 180.00 & $1,263.13$ \\
\hline \multicolumn{9}{|c|}{ Panel C: Bid outcome (\%) } \\
\hline 1998 & 172 & 34.19 & 34.08 & 0.00 & 4.61 & 20.87 & 59.97 & 100.00 \\
\hline 1999 & 153 & 47.42 & 36.50 & 0.00 & 16.43 & 41.07 & 85.84 & 100.00 \\
\hline 2000 & 224 & 46.87 & 36.15 & 0.00 & 11.10 & 44.34 & 81.69 & 100.00 \\
\hline 2001 & 274 & 43.49 & 36.53 & 0.00 & 5.57 & 40.94 & 78.28 & 100.00 \\
\hline 2002 & 166 & 43.28 & 35.79 & 0.00 & 4.21 & 40.00 & 77.14 & 100.00 \\
\hline 2003 & 227 & 37.62 & 35.45 & 0.00 & 2.51 & 26.33 & 71.70 & 100.00 \\
\hline 2004 & 257 & 27.29 & 33.28 & 0.00 & 0.55 & 8.21 & 51.00 & 100.00 \\
\hline 2005 & 65 & 25.70 & 31.91 & 0.00 & 0.52 & 8.93 & 43.45 & 100.00 \\
\hline 2006 & 64 & 18.33 & 26.74 & 0.00 & 0.11 & 2.10 & 27.80 & 95.09 \\
\hline 2007 & 65 & 24.60 & 35.00 & 0.00 & 0.00 & 3.26 & 40.00 & 100.00 \\
\hline 2008 & 45 & 28.33 & 32.12 & 0.00 & 0.35 & 12.31 & 61.92 & 100.00 \\
\hline 2009 & 26 & 19.52 & 28.62 & 0.00 & 1.02 & 8.58 & 22.84 & 93.63 \\
\hline 2010 & 35 & 14.30 & 20.15 & 0.00 & 0.23 & 4.73 & 19.88 & 65.68 \\
\hline 2011 & 24 & 26.80 & 25.91 & 0.09 & 4.33 & 18.17 & 46.77 & 87.45 \\
\hline 2012 & 17 & 15.61 & 23.92 & 0.00 & 0.00 & 2.04 & 21.73 & 85.49 \\
\hline Total & 1,814 & 36.34 & 35.54 & 0.00 & 1.72 & 24.89 & 69.67 & 100.00 \\
\hline
\end{tabular}


Table 3: Acquisition premiums and bid outcome and by regulatory regime

\begin{tabular}{|c|c|c|c|c|c|c|c|c|}
\hline Regime & $\mathrm{N}$ & Mean & St. dev. & Min & Q1 & Median & Q2 & Max \\
\hline \multicolumn{9}{|c|}{ Panel A: Initial bid premium(\%) } \\
\hline Regime 1 & 786 & 114.71 & 222.91 & -98.00 & 0.00 & 30.22 & 125.23 & 900.00 \\
\hline Regime 2 & 56 & 107.16 & 211.91 & -34.48 & 6.67 & 28.31 & 89.29 & 900.00 \\
\hline Regime 3 & 22 & 112.83 & 210.41 & 0.00 & 4.48 & 35.58 & 70.00 & 900.00 \\
\hline Regime 4 & 2 & 29.81 & 19.13 & 16.28 & 16.28 & 29.81 & 43.33 & 43.33 \\
\hline Regime 5 & 30 & 79.68 & 192.77 & -68.57 & -12.50 & 13.78 & 100.00 & 900.00 \\
\hline Regime 6 & 123 & 96.05 & 201.12 & -98.28 & 0.00 & 21.95 & 92.00 & 900.00 \\
\hline Regime 7 & 276 & 168.91 & 291.07 & -90.77 & 0.00 & 29.34 & 172.79 & 900.00 \\
\hline Regime 8 & 125 & 205.37 & 304.22 & -54.25 & 5.24 & 61.54 & 188.95 & 900.00 \\
\hline Regime 9 & 55 & 125.90 & 236.74 & -38.42 & 4.00 & 31.00 & 140.00 & 900.00 \\
\hline Regime 10 & 258 & 88.88 & 194.28 & -85.71 & 0.00 & 11.11 & 90.00 & 900.00 \\
\hline Total & 1,733 & 124.09 & 237.73 & -98.28 & 0.00 & 27.66 & 119.18 & 900.00 \\
\hline \multicolumn{9}{|c|}{ Panel B: Final premium (\%) } \\
\hline Regime 1 & 786 & 180.92 & 326.27 & -98.00 & 4.17 & 50.00 & 194.10 & $1,263.13$ \\
\hline Regime 2 & 56 & 150.04 & 292.10 & 0.00 & 7.70 & 47.10 & 145.00 & $1,263.13$ \\
\hline Regime 3 & 22 & 206.60 & 364.95 & -0.00 & 9.71 & 63.55 & 172.73 & $1,263.13$ \\
\hline Regime 4 & 2 & 29.81 & 19.13 & 16.28 & 16.28 & 29.81 & 43.33 & 43.33 \\
\hline Regime 5 & 30 & 154.48 & 301.17 & -68.57 & -3.51 & 33.97 & 187.36 & $1,263.13$ \\
\hline Regime 6 & 123 & 163.21 & 296.68 & -98.28 & 2.27 & 42.01 & 180.00 & $1,263.13$ \\
\hline Regime 7 & 276 & 222.45 & 371.70 & -90.77 & 4.08 & 49.84 & 266.35 & $1,263.13$ \\
\hline Regime 8 & 125 & 261.26 & 396.44 & -54.25 & 9.76 & 72.41 & 291.67 & $1,263.13$ \\
\hline Regime 9 & 55 & 192.18 & 352.77 & -38.42 & 4.00 & 47.06 & 204.35 & $1,263.13$ \\
\hline Regime 10 & 258 & 109.80 & 257.04 & -85.71 & 0.00 & 11.65 & 92.31 & $1,263.13$ \\
\hline Total & 1,733 & 180.54 & 329.79 & -98.28 & 1.63 & 43.26 & 180.00 & $1,263.13$ \\
\hline \multicolumn{9}{|c|}{ Panel C: Bid outcome (\%) } \\
\hline Regime 1 & 870 & 43.24 & 36.07 & 0.00 & 7.43 & 37.84 & 78.14 & 100.00 \\
\hline Regime 2 & 60 & 41.26 & 37.92 & 0.00 & 1.72 & 31.62 & 81.29 & 100.00 \\
\hline Regime 3 & 21 & 40.96 & 34.63 & 0.00 & 4.68 & 34.76 & 71.00 & 93.53 \\
\hline Regime 4 & 2 & 49.06 & 67.64 & 1.23 & 1.23 & 49.06 & 96.90 & 96.90 \\
\hline Regime 5 & 26 & 43.05 & 37.19 & 0.00 & 1.03 & 39.31 & 75.55 & 100.00 \\
\hline Regime 6 & 120 & 45.30 & 34.83 & 0.00 & 12.66 & 41.83 & 80.31 & 100.00 \\
\hline Regime 7 & 287 & 29.75 & 34.09 & 0.00 & 0.92 & 11.99 & 54.91 & 100.00 \\
\hline Regime 8 & 123 & 24.72 & 32.27 & 0.00 & 0.44 & 6.22 & 40.83 & 100.00 \\
\hline Regime 9 & 53 & 21.68 & 28.62 & 0.00 & 0.35 & 2.85 & 38.14 & 92.74 \\
\hline Regime 10 & 252 & 22.16 & 29.57 & 0.00 & 0.13 & 6.47 & 37.21 & 100.00 \\
\hline $\begin{array}{c}\text { Total } \\
\end{array}$ & 1,814 & 36.34 & 35.54 & 0.00 & 1.72 & 24.89 & 69.67 & 100.00 \\
\hline
\end{tabular}


Table 4: Bivariate comparison of initial bid premium, final bid premium, and bid outcome

\begin{tabular}{|c|c|c|c|c|c|c|c|c|c|c|c|c|c|}
\hline \multirow[t]{2}{*}{ 4.a. } & \multicolumn{3}{|c|}{ Global } & \multicolumn{3}{|c|}{ No toehold } & \multicolumn{3}{|c|}{ Positive toehold } & \multicolumn{4}{|c|}{ Difference test } \\
\hline & $\mathrm{N}$ & Mean & Median & $\mathrm{N}$ & Mean & Median & $\mathrm{N}$ & Mean & Median & t-stat & Chi2 & z-stat & $\mathrm{K}-\mathrm{W}$ \\
\hline Initial premium & 1,696 & 125.58 & 27.92 & 327 & 148.69 & 28.05 & 1,369 & 120.06 & 27.91 & $1.95^{\star}$ & 0.00 & 0.74 & 0.55 \\
\hline Final premium & 1,696 & 182.29 & 43.98 & 327 & 263.24 & 74.00 & 1,369 & 162.95 & 39.53 & $4.94^{* * *}$ & $10.64^{* * *}$ & $3.95^{\star \star *}$ & $15.61^{* * *}$ \\
\hline Bid outcome & 1,796 & 36.19 & 24.62 & 327 & 49.83 & 58.16 & 1,369 & 32.63 & 20.40 & $8.48^{* * *}$ & $42.53^{\star \star *}$ & $5.82^{\star \star *}$ & $33.73^{\star * *}$ \\
\hline \multirow{2}{*}{ 4.b. } & \multicolumn{3}{|c|}{ Global } & \multicolumn{3}{|c|}{ Toehold $<50 \%$} & \multicolumn{3}{|c|}{ Toehold $\geq 50 \% \&<90 \%$} & \multicolumn{4}{|c|}{ Difference test } \\
\hline & $\mathrm{N}$ & Mean & Median & $\mathrm{N}$ & Mean & Median & $\mathrm{N}$ & Mean & Median & t-stat & Chi2 & z-stat & K-W \\
\hline Initial premium & 1,076 & 98.11 & 25.00 & 698 & 85.01 & 25.00 & 378 & 122.31 & 25.00 & $-2.86^{\star * *}$ & 0.28 & $-1.7^{*}$ & $3.09^{*}$ \\
\hline Final premium & 1,076 & 143.63 & 36.36 & 698 & 128.38 & 33.33 & 378 & 171.78 & 40.59 & $-2.38^{\star *}$ & 0.46 & -1.31 & 1.71 \\
\hline Bid outcome & 1,111 & 37.31 & 27.08 & 718 & 38.79 & 28.65 & 393 & 34.60 & 23.17 & $1.91^{*}$ & 2.01 & $1.68^{*}$ & $2.82^{*}$ \\
\hline \multirow[t]{2}{*}{ 4.c. } & \multicolumn{3}{|c|}{ Global } & \multicolumn{3}{|c|}{ Pre-existing control } & \multicolumn{3}{|c|}{ Novel control } & \multicolumn{4}{|c|}{ Difference test } \\
\hline & $\mathrm{N}$ & Mean & Median & $\mathrm{N}$ & Mean & Median & $\mathrm{N}$ & Mean & Median & t-stat & Chi2 & z-stat & $\mathrm{K}-\mathrm{W}$ \\
\hline Initial premium & 1,248 & 131.69 & 26.79 & 911 & 138.92 & 30.00 & 337 & 112.14 & 20.00 & $1.69^{*}$ & $3.91^{* *}$ & $2.18^{* *}$ & $4.75^{* *}$ \\
\hline Final premium & 1,248 & 188.03 & 42.86 & 911 & 181.86 & 42.31 & 337 & 204.72 & 47.14 & -1.05 & 0.65 & -0.67 & 0.44 \\
\hline Bid outcome & 1,306 & 42.17 & 36.02 & 927 & 30.56 & 17.86 & 379 & 70.56 & 76.70 & $-21.33^{\star \star *}$ & $310.47^{\star * *}$ & $-18.20^{\star \star *}$ & $331.16^{* * *}$ \\
\hline \multirow[t]{2}{*}{ 4.d. } & \multicolumn{3}{|c|}{ Global } & \multicolumn{3}{|c|}{ Toehold $\geq 90 \%$} & \multicolumn{3}{|c|}{ Squeeze-out } & \multicolumn{4}{|c|}{ Difference test } \\
\hline & $\mathrm{N}$ & Mean & Median & $\mathrm{N}$ & Mean & Median & $\mathrm{N}$ & Mean & Median & t-stat & Chi2 & z-stat & $\mathrm{K}-\mathrm{W}$ \\
\hline Initial premium & 324 & 191.60 & 53.45 & 257 & 222.39 & 66.42 & 67 & 73.52 & 19.57 & $5.44^{* * *}$ & $4.82^{* *}$ & $3.08^{* * *}$ & $9.44^{\star * *}$ \\
\hline Final premium & 324 & 222.86 & 55.87 & 257 & 260.03 & 66.67 & 67 & 80.30 & 19.57 & $5.28^{\star * *}$ & $4.82^{* *}$ & $3.12^{* \star *}$ & $9.70^{\star \star *}$ \\
\hline Bid outcome & 344 & 18.75 & 6.44 & 277 & 15.24 & 5.08 & 67 & 33.28 & 19.50 & $-5.40^{* * *}$ & $5.36^{* *}$ & $-3.86^{* * *}$ & $14.86^{* * *}$ \\
\hline \multirow[t]{2}{*}{ 4.e. } & \multicolumn{3}{|c|}{ Global } & \multicolumn{3}{|c|}{ No AVAS foothold } & \multicolumn{3}{|c|}{ Positive AVAS foothold } & \multicolumn{4}{|c|}{ Difference test } \\
\hline & $\mathrm{N}$ & Mean & Median & $\mathrm{N}$ & Mean & Median & $\mathrm{N}$ & Mean & Median & t-stat & Chi2 & z-stat & K-W \\
\hline Initial premium & 1,733 & 124.09 & 27.66 & 1,370 & 105.34 & 25.00 & 363 & 194.86 & 52.17 & $-6.45^{\star \star *}$ & $16.69^{\star \star *}$ & $-5.64^{\star \star \star}$ & $31.77^{\star * *}$ \\
\hline Final premium & 1,733 & 180.54 & 43.26 & 1,370 & 161.30 & 38.89 & 363 & 253.16 & 69.00 & $-4.75^{* \star *}$ & $8.44^{* \star *}$ & $-4.45^{\star * *}$ & $19.82^{* * *}$ \\
\hline Bid outcome & 1,814 & 36.34 & 24.89 & 1,416 & 37.55 & 26.09 & 398 & 32.06 & 21.35 & $2.72^{\star * *}$ & $2.90^{*}$ & 1.55 & 2.38 \\
\hline 4.f. & & Glob & & & IS footho & $50 \%$ & & AS foothc & $50 \%$ & & Differe & ce test & \\
\hline & $\mathrm{N}$ & Mean & Median & $\mathrm{N}$ & Mean & Median & $\mathrm{N}$ & Mean & Median & t-stat & Chi2 & z-stat & K-W \\
\hline Initial premium & 1,283 & 131.31 & 28.66 & 730 & 112.95 & 25.00 & 553 & 155.55 & 33.33 & $-3.10^{* \star *}$ & 1.46 & $-1.75^{*}$ & $3.05^{*}$ \\
\hline Final premium & 1,283 & 188.76 & 44.53 & 730 & 169.40 & 41.34 & 553 & 214.31 & 50.00 & $-2.34^{* * *}$ & 1.46 & -1.38 & 1.90 \\
\hline Bid outcome & 1,328 & 36.40 & 25.09 & 740 & 38.16 & 27.39 & 588 & 34.20 & 23.26 & $2.02^{* *}$ & 1.22 & $2.05^{\star *}$ & $4.20^{\star *}$ \\
\hline 4.g. & & Glob & & Other & IVAS insi & $s \geq 50 \%$ & & Ider AVA & $50 \%$ & & Differe & ce test & \\
\hline & $\mathrm{N}$ & Mean & Median & $\mathrm{N}$ & Mean & Median & $\mathrm{N}$ & Mean & Median & t-stat & Chi2 & z-stat & K-W \\
\hline Initial premium & 553 & 155.55 & 33.33 & 352 & 111.74 & 23.57 & 201 & 232.25 & 66.66 & $-5.17^{* * *}$ & $9.77^{* * *}$ & $-4.42^{* * *}$ & $19.59^{* * *}$ \\
\hline Final premium & 553 & 214.31 & 50.00 & 352 & 167.86 & 41.58 & 201 & 295.66 & 77.96 & $-4.01^{* * *}$ & $8.04^{* * *}$ & $-4.01^{* * *}$ & $16.05^{* * *}$ \\
\hline Bid outcome & 588 & 34.19 & 23.25 & 363 & 37.68 & 27.08 & 225 & 28.56 & 17.95 & $3.12^{\star \star *}$ & $3.80^{*}$ & $2.07^{\star \star}$ & $4.31^{\star *}$ \\
\hline
\end{tabular}


Table 4: Bivariate comparison of initial bid premium, final bid premium, and bid outcome (cont.)

\begin{tabular}{|c|c|c|c|c|c|c|c|c|c|c|c|c|c|}
\hline \multirow[t]{2}{*}{ 4.h. } & \multicolumn{3}{|c|}{ Global } & \multicolumn{3}{|c|}{ Short-term toehold } & \multicolumn{3}{|c|}{ No short-term toehold } & \multicolumn{4}{|c|}{ Difference test } \\
\hline & $\mathrm{N}$ & Mean & Median & $\mathrm{N}$ & Mean & Median & $\mathrm{N}$ & Mean & Median & t-stat & Chi2 & z-stat & $\mathrm{K}-\mathrm{W}$ \\
\hline Initial premium & 275 & 96.58 & 14.71 & 81 & 38.20 & 6.20 & 194 & 120.95 & 21.74 & $-3.15^{\star \star *}$ & $3.79^{*}$ & $-2.80^{\star \star \star}$ & $7.86^{\star \star \star}$ \\
\hline Final premium & 275 & 119.84 & 16.28 & 81 & 38.20 & 6.20 & 194 & 153.93 & 25.50 & $-3.32^{\star * \star}$ & $6.12^{\star *}$ & $-3.16^{\star \star *}$ & $9.93^{* * *}$ \\
\hline Bid outcome & 268 & 21.75 & 5.80 & 81 & 19.71 & 4.83 & 187 & 22.63 & 5.99 & -0.75 & 0.02 & -0.55 & 0.30 \\
\hline \multirow[t]{2}{*}{ 4.i. } & \multicolumn{3}{|c|}{ Global } & \multicolumn{3}{|c|}{ No rival bid } & \multicolumn{3}{|c|}{ Rival bid } & \multicolumn{4}{|c|}{ Difference test } \\
\hline & $\mathrm{N}$ & Mean & Median & $\mathrm{N}$ & Mean & Median & $\mathrm{N}$ & Mean & Median & t-stat & Chi2 & z-stat & K-W \\
\hline Initial premium & 1,733 & 124.09 & 27.66 & 1,582 & 120.94 & 26.58 & 151 & 157.14 & 31.87 & $-1.79^{*}$ & 0.89 & -1.58 & 2.49 \\
\hline Final premium & 1,733 & 180.54 & 43.26 & 1,582 & 169.23 & 39.53 & 151 & 299.04 & 120.00 & $-4.65^{\star * *}$ & $22.02^{* \star *}$ & $-5.03^{\star * *}$ & $25.31^{* * *}$ \\
\hline Bid outcome & 1,814 & 36.34 & 24.89 & 1,668 & 37.21 & 26.54 & 146 & 26.44 & 0.06 & $3.52^{* * *}$ & $17.16^{\text {***}}$ & $6.59^{* * *}$ & $43.30^{* * *}$ \\
\hline \multirow[t]{2}{*}{ 4.j. } & \multicolumn{3}{|c|}{ Global } & \multicolumn{3}{|c|}{ No price revision } & \multicolumn{3}{|c|}{ Price revision } & \multicolumn{4}{|c|}{ Difference test } \\
\hline & $\mathrm{N}$ & Mean & Median & $\mathrm{N}$ & Mean & Median & $\mathrm{N}$ & Mean & Median & t-stat & Chi2 & z-stat & K-W \\
\hline Initial premium & 1,733 & 124.09 & 27.66 & 1,446 & 128.79 & 30.00 & 287 & 100.46 & 20.00 & $1.85^{\star}$ & $5.67^{*}$ & $2.27^{\star \star}$ & $5.13^{* \star}$ \\
\hline Final premium & 1,733 & 180.54 & 43.26 & 1,446 & 145.14 & 30.00 & 287 & 358.88 & 184.00 & $-10.33^{\star \star \star *}$ & $116.69^{* * *}$ & $-12.41^{* * *}$ & $153.80^{* * *}$ \\
\hline Bid outcome & 1,814 & 36.34 & 24.89 & 1,515 & 34.27 & 21.52 & 299 & 46.85 & 49.45 & $-5.64^{* * *}$ & $30.31^{* * *}$ & $-4.35^{\star \star *}$ & $18.87^{\star \star \star}$ \\
\hline \multirow[t]{2}{*}{$4 . k$} & \multicolumn{3}{|c|}{ Global } & \multicolumn{3}{|c|}{ No period revision } & \multicolumn{3}{|c|}{ Period revision } & \multicolumn{4}{|c|}{ Difference test } \\
\hline & $\mathrm{N}$ & Mean & Median & $\mathrm{N}$ & Mean & Median & $\mathrm{N}$ & Mean & Median & t-stat & Chi2 & z-stat & $\mathrm{K}-\mathrm{W}$ \\
\hline Initial premium & 1,601 & 124.41 & 25.00 & 1,262 & 132.92 & 28.21 & 339 & 92.72 & 19.83 & $2.75^{\star \star \star}$ & $4.53^{* \star *}$ & $1.75^{*}$ & $3.05^{*}$ \\
\hline Final premium & 1,601 & 183.87 & 42.86 & 1,262 & 180.48 & 38.89 & 339 & 196.49 & 63.93 & -0.78 & $6.01^{* *}$ & $-2.91^{\star \star *}$ & $8.57^{* * *}$ \\
\hline \multirow[t]{2}{*}{ 4.I. } & \multicolumn{3}{|c|}{ Global } & \multicolumn{3}{|c|}{ No equity change } & \multicolumn{3}{|c|}{ Equity change } & \multicolumn{4}{|c|}{ Difference test } \\
\hline & $\mathrm{N}$ & Mean & Median & $\mathrm{N}$ & Mean & Median & $\mathrm{N}$ & Mean & Median & t-stat & Chi2 & z-stat & K-W \\
\hline Initial premium & 1,733 & 124.09 & 27.66 & 753 & 137.85 & 36.36 & 980 & 113.52 & 23.67 & $2.11^{* *}$ & $10.68^{\star \star \star}$ & $3.39^{* * *}$ & $11.51^{* * *}$ \\
\hline Final premium & 1,733 & 180.54 & 43.26 & 753 & 209.21 & 59.09 & 980 & 158.51 & 32.17 & $3.18^{* * *}$ & $11.98^{* * *}$ & $4.63^{\star \star *}$ & $21.47^{* * *}$ \\
\hline Bid outcome & 1,814 & 36.34 & 24.89 & 827 & 39.87 & 29.95 & 987 & 33.38 & 19.50 & $3.89^{* * *}$ & $13.18^{* * *}$ & $3.97^{* \star *}$ & $15.72^{* * *}$ \\
\hline
\end{tabular}


Table 5: Acquisition premiums - Ordinary Last Squares (OLS) regressions

\begin{tabular}{|c|c|c|c|c|c|c|c|c|c|c|}
\hline Independent variable & (1) & $(2)$ & $\begin{array}{c}(3) \\
\text { Initial premium }\end{array}$ & (4) & (5) & (6) & (7) & $\begin{array}{c}\text { (8) } \\
\text { Final premium }\end{array}$ & (9) & (10) \\
\hline 52-week High & $\begin{array}{l}1.203^{\star * \star} \\
(0.000)\end{array}$ & $\begin{array}{l}1.204^{* * *} \\
(0.000)\end{array}$ & $\begin{array}{c}1.197^{\star \star \star *} \\
(0.000)\end{array}$ & $\begin{array}{l}1.199^{* * *} \\
(0.000)\end{array}$ & $\begin{array}{l}1.203^{* * *} \\
(0.000)\end{array}$ & $\begin{array}{l}1.457^{* * *} \\
(0.000)\end{array}$ & $\begin{array}{l}1.465^{* \star *} \\
(0.000)\end{array}$ & $\begin{array}{c}1.434^{\star \star \star} \\
(0.000)\end{array}$ & $\begin{array}{l}1.445^{\text {***}} \\
(0.000)\end{array}$ & $\begin{array}{l}1.442^{* * *} \\
(0.000)\end{array}$ \\
\hline Financial dilution & $\begin{array}{c}6.446 \\
(0.656)\end{array}$ & $\begin{array}{c}5.898 \\
(0.682)\end{array}$ & $\begin{array}{c}7.288 \\
(0.618)\end{array}$ & $\begin{array}{c}7.177 \\
(0.624)\end{array}$ & $\begin{array}{c}3.779 \\
(0.797)\end{array}$ & $\begin{array}{l}28.245 \\
(0.245)\end{array}$ & $\begin{array}{l}26.446 \\
(0.280)\end{array}$ & $\begin{array}{l}30.350 \\
(0.215)\end{array}$ & $\begin{array}{l}28.368 \\
(0.252)\end{array}$ & $\begin{array}{l}25.958 \\
(0.291)\end{array}$ \\
\hline Equity change & $\begin{array}{c}-11.457 \\
(0.150)\end{array}$ & $\begin{array}{c}-10.960 \\
(0.175)\end{array}$ & $\begin{array}{c}-11.072 \\
(0.167)\end{array}$ & $\begin{array}{c}-10.303 \\
(0.207)\end{array}$ & $\begin{array}{c}-11.244 \\
(0.160)\end{array}$ & $\begin{array}{r}-17.297 \\
(0.195)\end{array}$ & $\begin{array}{c}-20.389 \\
(0.137)\end{array}$ & $\begin{array}{c}-15.971 \\
(0.234)\end{array}$ & $\begin{array}{c}-17.952 \\
(0.194)\end{array}$ & $\begin{array}{r}-16.801 \\
(0.209)\end{array}$ \\
\hline Direct toehold & $\begin{array}{l}-0.050 \\
(0.639)\end{array}$ & & $\begin{array}{l}-0.049 \\
(0.738)\end{array}$ & & & $\begin{array}{c}-0.338^{*} \\
(0.071)\end{array}$ & & $\begin{array}{l}-0.069 \\
(0.778)\end{array}$ & & \\
\hline Indirect toehold & & $\begin{array}{l}-0.090 \\
(0.405)\end{array}$ & & $\begin{array}{l}-0.107 \\
(0.445)\end{array}$ & & & $\begin{array}{c}-0.480^{* *} \\
(0.010)\end{array}$ & & $\begin{array}{l}-0.289 \\
(0.232)\end{array}$ & \\
\hline Zero toehold & & & $\begin{array}{c}8.770 \\
(0.416)\end{array}$ & $\begin{array}{c}3.317 \\
(0.757)\end{array}$ & & & & $\begin{array}{c}47.107^{* * *} \\
(0.009)\end{array}$ & $\begin{array}{l}34.341^{*} \\
(0.059)\end{array}$ & \\
\hline Direct toehold $\in(0 ; 33 \%)$ & & & & & $\begin{array}{c}-13.409 \\
(0.188)\end{array}$ & & & & & $\begin{array}{c}-55.567^{\text {*** }} \\
(0.001)\end{array}$ \\
\hline Direct toehold $\in[33 \% ; 50 \%)$ & & & & & $\begin{array}{l}-6.383 \\
(0.598)\end{array}$ & & & & & $\begin{array}{c}-50.002^{* *} \\
(0.015)\end{array}$ \\
\hline Direct toehold $\in[50 \% ; 90 \%)$ & & & & & $\begin{array}{c}1.577 \\
(0.890)\end{array}$ & & & & & $\begin{array}{c}-22.099 \\
(0.258)\end{array}$ \\
\hline Direct toehold $\in[90 \% ; 100 \%)$ & & & & & $\begin{array}{c}-26.260^{* *} \\
(0.048)\end{array}$ & & & & & $\begin{array}{c}-72.205^{\star * *} \\
(0.002)\end{array}$ \\
\hline AVAS foothold & & & $\begin{array}{c}8.047 \\
(0.405)\end{array}$ & $\begin{array}{c}5.707 \\
(0.553)\end{array}$ & $\begin{array}{c}6.505 \\
(0.504)\end{array}$ & & & $\begin{array}{l}11.198 \\
(0.489)\end{array}$ & $\begin{array}{c}9.738 \\
(0.550)\end{array}$ & $\begin{array}{c}7.419 \\
(0.649)\end{array}$ \\
\hline Rival & & & & & & $\begin{array}{c}130.898^{* * *} \\
(0.000)\end{array}$ & $\begin{array}{c}134.129^{* * *} \\
(0.000)\end{array}$ & $\begin{array}{c}127.321^{* * *} \\
(0.000)\end{array}$ & $\begin{array}{c}131.895^{* * *} \\
(0.000)\end{array}$ & $\begin{array}{c}128.231^{* * *} \\
(0.000)\end{array}$ \\
\hline Regulatory regime 2 & $\begin{array}{c}-36.848^{* *} \\
(0.040)\end{array}$ & $\begin{array}{c}-36.148^{*} \\
(0.063)\end{array}$ & $\begin{array}{c}-35.490^{* *} \\
(0.049)\end{array}$ & $\begin{array}{c}-34.807^{*} \\
(0.076)\end{array}$ & $\begin{array}{c}-34.983^{*} \\
(0.071)\end{array}$ & $\begin{array}{c}-69.606^{* *} \\
(0.031)\end{array}$ & $\begin{array}{c}-74.385^{\star *} \\
(0.024)\end{array}$ & $\begin{array}{c}-75.747^{* *} \\
(0.019)\end{array}$ & $\begin{array}{c}-78.271^{* *} \\
(0.018)\end{array}$ & $\begin{array}{c}-76.725^{\star *} \\
(0.010)\end{array}$ \\
\hline Regulatory regime 3 & $\begin{array}{c}-25.634 \\
(0.408)\end{array}$ & $\begin{array}{c}-12.882 \\
(0.689)\end{array}$ & $\begin{array}{c}-27.071 \\
(0.384)\end{array}$ & $\begin{array}{c}-13.952 \\
(0.666)\end{array}$ & $\begin{array}{c}-25.990 \\
(0.402)\end{array}$ & $\begin{array}{l}-7.014 \\
(0.893)\end{array}$ & $\begin{array}{c}7.611 \\
(0.889)\end{array}$ & $\begin{array}{c}-12.168 \\
(0.815)\end{array}$ & $\begin{array}{c}3.442 \\
(0.950)\end{array}$ & $\begin{array}{c}-10.070 \\
(0.846)\end{array}$ \\
\hline Regulatory regime 4 & $\begin{array}{c}5.326 \\
(0.956)\end{array}$ & $\begin{array}{c}5.491 \\
(0.954)\end{array}$ & $\begin{array}{c}3.161 \\
(0.974)\end{array}$ & $\begin{array}{c}8.581 \\
(0.929)\end{array}$ & $\begin{array}{l}-0.198 \\
(0.998)\end{array}$ & $\begin{array}{c}-18.346 \\
(0.910)\end{array}$ & $\begin{array}{c}-19.663 \\
(0.903)\end{array}$ & $\begin{array}{l}-5.539 \\
(0.973)\end{array}$ & $\begin{array}{l}-2.033 \\
(0.990)\end{array}$ & $\begin{array}{c}-12.688 \\
(0.938)\end{array}$ \\
\hline Regulatory regime 5 & $\begin{array}{c}-10.885 \\
(0.680)\end{array}$ & $\begin{array}{l}-9.952 \\
(0.702)\end{array}$ & $\begin{array}{c}-13.945 \\
(0.599)\end{array}$ & $\begin{array}{c}-13.058 \\
(0.619)\end{array}$ & $\begin{array}{c}-10.465 \\
(0.693)\end{array}$ & $\begin{array}{l}-1.244 \\
(0.978)\end{array}$ & $\begin{array}{c}-0.473 \\
(0.991)\end{array}$ & $\begin{array}{l}-8.242 \\
(0.853)\end{array}$ & $\begin{array}{l}-6.909 \\
(0.877)\end{array}$ & $\begin{array}{l}-1.263 \\
(0.977)\end{array}$ \\
\hline Regulatory regime 6 & $\begin{array}{c}-30.367^{* *} \\
(0.026)\end{array}$ & $\begin{array}{c}-28.403^{* *} \\
(0.038)\end{array}$ & $\begin{array}{c}-28.740^{* *} \\
(0.036)\end{array}$ & $\begin{array}{c}-26.701^{* *} \\
(0.040)\end{array}$ & $\begin{array}{c}-26.589^{\star *} \\
(0.053)\end{array}$ & $\begin{array}{c}-22.705 \\
(0.323)\end{array}$ & $\begin{array}{c}-18.099 \\
(0.436)\end{array}$ & $\begin{array}{c}-20.247 \\
(0.378)\end{array}$ & $\begin{array}{c}-15.300 \\
(0.512)\end{array}$ & $\begin{array}{c}-17.182 \\
(0.455)\end{array}$ \\
\hline Regulatory regime 7 & $\begin{array}{c}-36.898^{\star \star \star} \\
(0.000)\end{array}$ & $\begin{array}{c}-34.517^{\star \star *} \\
(0.001)\end{array}$ & $\begin{array}{c}-35.910^{\star * *} \\
(0.001)\end{array}$ & $\begin{array}{c}-34.158^{\star \star *} \\
(0.002)\end{array}$ & $\begin{array}{c}-30.267^{* * *} \\
(0.006)\end{array}$ & $\begin{array}{c}-65.214^{\star * *} \\
(0.000)\end{array}$ & $\begin{array}{c}-61.704^{\star * *} \\
(0.001)\end{array}$ & $\begin{array}{c}-67.468^{* \star *} \\
(0.000)\end{array}$ & $\begin{array}{c}-63.510^{* * *} \\
(0.001)\end{array}$ & $\begin{array}{c}-59.265^{\star * *} \\
(0.001)\end{array}$ \\
\hline
\end{tabular}




\begin{tabular}{|c|c|c|c|c|c|c|c|c|c|c|}
\hline Regulatory regime 8 & $\begin{array}{c}-51.906^{* * *} \\
(0.000)\end{array}$ & $\begin{array}{c}-53.220^{* * *} \\
(0.000)\end{array}$ & $\begin{array}{c}-50.246^{* * *} \\
(0.001)\end{array}$ & $\begin{array}{c}-52.624^{* * *} \\
(0.000)\end{array}$ & $\begin{array}{c}-47.510^{* * *} \\
(0.001)\end{array}$ & $\begin{array}{c}-79.734^{* * *} \\
(0.001)\end{array}$ & $\begin{array}{c}-79.828^{* * *} \\
(0.001)\end{array}$ & $\begin{array}{c}-81.349^{* * *} \\
(0.001)\end{array}$ & $\begin{array}{c}-81.346^{* * *} \\
(0.001)\end{array}$ & $\begin{array}{c}-77.881^{* * *} \\
(0.001)\end{array}$ \\
\hline Regulatory regime 9 & $\begin{array}{c}-32.397^{* *} \\
(0.045)\end{array}$ & $\begin{array}{c}-28.815^{*} \\
(0.078)\end{array}$ & $\begin{array}{c}-27.983^{*} \\
(0.097)\end{array}$ & $\begin{array}{r}-26.025 \\
(0.190)\end{array}$ & $\begin{array}{c}-30.053^{*} \\
(0.076)\end{array}$ & $\begin{array}{c}-24.398 \\
(0.459)\end{array}$ & $\begin{array}{c}-16.686 \\
(0.615)\end{array}$ & $\begin{array}{r}-22.941 \\
(0.490)\end{array}$ & $\begin{array}{c}-16.456 \\
(0.624)\end{array}$ & $\begin{array}{r}-28.121 \\
(0.396)\end{array}$ \\
\hline Regulatory regime 10 & $\begin{array}{c}-17.429^{*} \\
(0.085)\end{array}$ & $\begin{array}{c}-15.253 \\
(0.162)\end{array}$ & $\begin{array}{c}-12.048 \\
(0.291)\end{array}$ & $\begin{array}{c}-12.000 \\
(0.301)\end{array}$ & $\begin{array}{c}-14.032 \\
(0.220)\end{array}$ & $\begin{array}{c}-43.846^{* * *} \\
(0.007)\end{array}$ & $\begin{array}{c}-37.570^{* *} \\
(0.029)\end{array}$ & $\begin{array}{c}-41.403^{* *} \\
(0.025)\end{array}$ & $\begin{array}{c}-37.280^{*} \\
(0.057)\end{array}$ & $\begin{array}{c}-46.973^{* *} \\
(0.010)\end{array}$ \\
\hline Joint stock company & & & $\begin{array}{c}5.135 \\
(0.604)\end{array}$ & $\begin{array}{c}6.626 \\
(0.514)\end{array}$ & $\begin{array}{c}3.983 \\
(0.687)\end{array}$ & & & $\begin{array}{l}-9.326 \\
(0.574)\end{array}$ & $\begin{array}{l}-6.365 \\
(0.711)\end{array}$ & $\begin{array}{c}-12.128 \\
(0.464)\end{array}$ \\
\hline Limited liability company & & & $\begin{array}{l}13.404 \\
(0.140)\end{array}$ & $\begin{array}{l}14.524 \\
(0.115)\end{array}$ & $\begin{array}{l}11.492 \\
(0.207)\end{array}$ & & & $\begin{array}{c}30.449^{* *} \\
(0.045)\end{array}$ & $\begin{array}{c}30.172^{*} \\
(0.053)\end{array}$ & $\begin{array}{l}26.458^{*} \\
(0.082)\end{array}$ \\
\hline Foreign company & & & $\begin{array}{c}2.599 \\
(0.830)\end{array}$ & $\begin{array}{c}2.642 \\
(0.827)\end{array}$ & $\begin{array}{c}2.269 \\
(0.851)\end{array}$ & & & $\begin{array}{c}-16.011 \\
(0.430)\end{array}$ & $\begin{array}{c}-14.712 \\
(0.473)\end{array}$ & $\begin{array}{c}-18.176 \\
(0.370)\end{array}$ \\
\hline Financial investor & & & $\begin{array}{l}13.206 \\
(0.359)\end{array}$ & $\begin{array}{l}-0.242 \\
(0.988)\end{array}$ & $\begin{array}{l}11.239 \\
(0.435)\end{array}$ & & & $\begin{array}{c}5.239 \\
(0.828)\end{array}$ & $\begin{array}{l}-8.004 \\
(0.761)\end{array}$ & $\begin{array}{c}1.204 \\
(0.960)\end{array}$ \\
\hline Group & & & $\begin{array}{r}-18.370 \\
(0.471)\end{array}$ & $\begin{array}{c}-18.464 \\
(0.464)\end{array}$ & $\begin{array}{c}-18.308 \\
(0.472)\end{array}$ & & & $\begin{array}{l}21.539 \\
(0.614)\end{array}$ & $\begin{array}{l}21.133 \\
(0.621)\end{array}$ & $\begin{array}{l}20.409 \\
(0.632)\end{array}$ \\
\hline SIF & & & $\begin{array}{l}-4.037 \\
(0.852)\end{array}$ & $\begin{array}{l}-6.104 \\
(0.776)\end{array}$ & $\begin{array}{l}-4.951 \\
(0.820)\end{array}$ & & & $\begin{array}{c}-37.890^{*} \\
(0.083)\end{array}$ & $\begin{array}{c}-41.808^{*} \\
(0.061)\end{array}$ & $\begin{array}{c}-39.183^{*} \\
(0.080)\end{array}$ \\
\hline $\mathrm{N}$ & 1,696 & 1,592 & 1,696 & 1,586 & 1,696 & 1,696 & 1,592 & 1,696 & 1,586 & 1,696 \\
\hline R2 & 0.679 & 0.693 & 0.680 & 0.694 & 0.681 & 0.529 & 0.543 & 0.534 & 0.547 & 0.536 \\
\hline Adjusted R2 & 0.676 & 0.690 & 0.676 & 0.690 & 0.677 & 0.525 & 0.539 & 0.528 & 0.541 & 0.529 \\
\hline F-stat & $309.3^{* * *}$ & $306.6^{* \star *}$ & $191.8^{* \star *}$ & $192.8^{* \star *}$ & $175.0^{* * *}$ & $111.9^{* * *}$ & $111.9^{\star * *}$ & $70.7^{\star * \star}$ & $71.1^{* * *}$ & $65.4^{\star \star *}$ \\
\hline H0: Regimes jointly zero & $3.852^{* * *}$ & $3.721^{* * *}$ & $3.285^{\star * *}$ & $3.353^{\star * *}$ & $2.790^{* * *}$ & $2.629^{* * *}$ & $2.392^{* *}$ & $2.492^{* \star *}$ & $2.398^{* *}$ & $2.218^{\star *}$ \\
\hline H0: Regimes same effect & $2.121^{* *}$ & $2.456^{* *}$ & $1.806^{\star}$ & $2.286^{\star *}$ & 1.471 & $1.711^{*}$ & $1.807^{\star}$ & 1.557 & $1.866^{*}$ & 1.273 \\
\hline
\end{tabular}

Note: dependent variables (initial and final bid premiums) are winsorized at the $95 \%$ level; robust standard errors are computed using the Huber-White sandwich estimators; constant included but not reported 
Table 6: Acquisition premiums - robust (median) regressions

\begin{tabular}{|c|c|c|c|c|c|c|c|c|c|c|}
\hline \multirow{2}{*}{ Independent variable } & 1 & 2 & 3 & 4 & 5 & 6 & 7 & 8 & 9 & 10 \\
\hline & \multicolumn{5}{|c|}{ Initial premium } & \multicolumn{5}{|c|}{ Final premium } \\
\hline 52-week High & $\begin{array}{l}1.101^{* * *} \\
(0.000)\end{array}$ & $\begin{array}{l}1.122^{* \star *} \\
(0.000)\end{array}$ & $\begin{array}{c}1.110^{* \star *} \\
(0.000)\end{array}$ & $\begin{array}{l}1.121^{* \star *} \\
(0.000)\end{array}$ & $\begin{array}{l}1.107^{* \star *} \\
(0.000)\end{array}$ & $\begin{array}{l}1.209^{* * *} \\
(0.000)\end{array}$ & $\begin{array}{l}1.226^{* \star *} \\
(0.000)\end{array}$ & $\begin{array}{c}1.197^{\star \star \star *} \\
(0.000)\end{array}$ & $\begin{array}{l}1.214^{* * *} \\
(0.000)\end{array}$ & $\begin{array}{l}1.207^{* \star *} \\
(0.000)\end{array}$ \\
\hline Financial dilution & $\begin{array}{l}1.600 \\
(0.788)\end{array}$ & $\begin{array}{c}2.528 \\
(0.687)\end{array}$ & $\begin{array}{c}1.367 \\
(0.826)\end{array}$ & $\begin{array}{c}2.542 \\
(0.708)\end{array}$ & $\begin{array}{l}-1.459 \\
(0.810)\end{array}$ & $\begin{array}{c}3.159 \\
(0.647)\end{array}$ & $\begin{array}{l}5.266 \\
(0.443)\end{array}$ & $\begin{array}{c}4.077 \\
(0.623)\end{array}$ & $\begin{array}{c}3.988 \\
(0.627)\end{array}$ & $\begin{array}{c}0.318 \\
(0.965)\end{array}$ \\
\hline Equity change & $\begin{array}{c}1.701 \\
(0.709)\end{array}$ & $\begin{array}{c}0.925 \\
(0.844)\end{array}$ & $\begin{array}{c}0.312 \\
(0.936)\end{array}$ & $\begin{array}{l}-0.850 \\
(0.834)\end{array}$ & $\begin{array}{c}1.138 \\
(0.776)\end{array}$ & $\begin{array}{l}-1.645 \\
(0.763)\end{array}$ & $\begin{array}{l}-6.138 \\
(0.326)\end{array}$ & $\begin{array}{l}-2.691 \\
(0.638)\end{array}$ & $\begin{array}{l}-6.456 \\
(0.302)\end{array}$ & $\begin{array}{l}-4.154 \\
(0.468)\end{array}$ \\
\hline Direct toehold & $\begin{array}{l}-0.000 \\
(0.998)\end{array}$ & & $\begin{array}{l}-0.108 \\
(0.118)\end{array}$ & & & $\begin{array}{c}-0.147^{* *} \\
(0.028)\end{array}$ & & $\begin{array}{c}-0.131^{*} \\
(0.095)\end{array}$ & & \\
\hline Indirect toehold & & $\begin{array}{c}0.033 \\
(0.538)\end{array}$ & & $\begin{array}{l}-0.047 \\
(0.469)\end{array}$ & & & $\begin{array}{l}-0.101 \\
(0.209)\end{array}$ & & $\begin{array}{l}-0.113 \\
(0.186)\end{array}$ & \\
\hline Zero toehold & & & $\begin{array}{l}-9.921^{*} \\
(0.066)\end{array}$ & $\begin{array}{l}-4.970 \\
(0.324)\end{array}$ & & & & $\begin{array}{c}0.239 \\
(0.978)\end{array}$ & $\begin{array}{l}2.854 \\
(0.742)\end{array}$ & \\
\hline Direct toehold $\in(0 ; 33 \%)$ & & & & & $\begin{array}{c}6.762 \\
(0.189)\end{array}$ & & & & & $\begin{array}{l}-3.612 \\
(0.651)\end{array}$ \\
\hline Direct toehold $\in[33 \% ; 50 \%)$ & & & & & $\begin{array}{l}3.655 \\
(0.503)\end{array}$ & & & & & $\begin{array}{l}-5.513 \\
(0.526)\end{array}$ \\
\hline Direct toehold $\in[50 \% ; 90 \%)$ & & & & & $\begin{array}{l}9.307 \\
(0.118)\end{array}$ & & & & & $\begin{array}{c}2.001 \\
(0.821)\end{array}$ \\
\hline Direct toehold $\in[90 \% ; 100 \%)$ & & & & & $\begin{array}{l}-2.940 \\
(0.577)\end{array}$ & & & & & $\begin{array}{c}-17.334^{\star *} \\
(0.033)\end{array}$ \\
\hline AVAS foothold & & & $\begin{array}{c}-7.845^{*} \\
(0.095)\end{array}$ & $\begin{array}{l}-6.587 \\
(0.190)\end{array}$ & $\begin{array}{l}-5.933 \\
(0.198)\end{array}$ & & & $\begin{array}{l}-3.999 \\
(0.506)\end{array}$ & $\begin{array}{l}-5.630 \\
(0.328)\end{array}$ & $\begin{array}{l}-2.634 \\
(0.639)\end{array}$ \\
\hline Rival & & & & & & $\begin{array}{c}48.050^{* *} \\
(0.017)\end{array}$ & $\begin{array}{l}44.953^{*} \\
(0.079)\end{array}$ & $\begin{array}{c}46.009^{* *} \\
(0.042)\end{array}$ & $\begin{array}{l}42.678 \\
(0.118)\end{array}$ & $\begin{array}{l}48.074^{* *} \\
(0.029)\end{array}$ \\
\hline Regulatory regime 2 & $\begin{array}{c}-21.979^{*} \\
(0.091)\end{array}$ & $\begin{array}{c}-30.692^{\star *} \\
(0.031)\end{array}$ & $\begin{array}{c}-15.008 \\
(0.225)\end{array}$ & $\begin{array}{c}-21.620^{*} \\
(0.077)\end{array}$ & $\begin{array}{r}-17.867 \\
(0.170)\end{array}$ & $\begin{array}{c}-29.483^{*} \\
(0.098)\end{array}$ & $\begin{array}{c}-34.153^{*} \\
(0.061)\end{array}$ & $\begin{array}{c}-24.990 \\
(0.205)\end{array}$ & $\begin{array}{c}-28.090 \\
(0.125)\end{array}$ & $\begin{array}{c}-30.866 \\
(0.122)\end{array}$ \\
\hline Regulatory regime 3 & $\begin{array}{c}4.457 \\
(0.865)\end{array}$ & $\begin{array}{c}5.524 \\
(0.852)\end{array}$ & $\begin{array}{c}4.249 \\
(0.874)\end{array}$ & $\begin{array}{c}6.864 \\
(0.822)\end{array}$ & $\begin{array}{c}4.527 \\
(0.872)\end{array}$ & $\begin{array}{l}27.365 \\
(0.383)\end{array}$ & $\begin{array}{l}26.894 \\
(0.361)\end{array}$ & $\begin{array}{l}25.509 \\
(0.444)\end{array}$ & $\begin{array}{l}22.546 \\
(0.469)\end{array}$ & $\begin{array}{l}23.664 \\
(0.561)\end{array}$ \\
\hline Regulatory regime 4 & $\begin{array}{c}62.243^{* *} \\
(0.025)\end{array}$ & $\begin{array}{c}63.659^{* *} \\
(0.029)\end{array}$ & $\begin{array}{c}5.727 \\
(0.834)\end{array}$ & $\begin{array}{c}5.881 \\
(0.831)\end{array}$ & $\begin{array}{l}-6.314 \\
(0.836)\end{array}$ & $\begin{array}{l}49.872^{* *} \\
(0.046)\end{array}$ & $\begin{array}{c}51.546^{* *} \\
(0.044)\end{array}$ & $\begin{array}{l}-0.716 \\
(0.978)\end{array}$ & $\begin{array}{c}0.565 \\
(0.984)\end{array}$ & $\begin{array}{l}48.636 \\
(0.110)\end{array}$ \\
\hline Regulatory regime 5 & $\begin{array}{r}-15.108 \\
(0.231)\end{array}$ & $\begin{array}{r}-15.790 \\
(0.261)\end{array}$ & $\begin{array}{l}-4.517 \\
(0.753)\end{array}$ & $\begin{array}{l}-9.811 \\
(0.524)\end{array}$ & $\begin{array}{l}-5.601 \\
(0.717)\end{array}$ & $\begin{array}{c}0.216 \\
(0.992)\end{array}$ & $\begin{array}{c}1.496 \\
(0.940)\end{array}$ & $\begin{array}{l}10.135 \\
(0.618)\end{array}$ & $\begin{array}{c}7.243 \\
(0.756)\end{array}$ & $\begin{array}{l}-1.725 \\
(0.942)\end{array}$ \\
\hline Regulatory regime 6 & $\begin{array}{c}-16.981^{* * *} \\
(0.005)\end{array}$ & $\begin{array}{c}-17.213^{* * *} \\
(0.009)\end{array}$ & $\begin{array}{c}-12.024^{*} \\
(0.076)\end{array}$ & $\begin{array}{c}-15.258^{* *} \\
(0.032)\end{array}$ & $\begin{array}{c}-12.326^{*} \\
(0.058)\end{array}$ & $\begin{array}{c}-20.984^{* *} \\
(0.017)\end{array}$ & $\begin{array}{c}-21.809^{* *} \\
(0.021)\end{array}$ & $\begin{array}{c}-20.406^{* *} \\
(0.023)\end{array}$ & $\begin{array}{c}-19.015^{\star *} \\
(0.044)\end{array}$ & $\begin{array}{c}-20.370^{* *} \\
(0.015)\end{array}$ \\
\hline Regulatory regime 7 & $\begin{array}{c}-33.707^{\star * *} \\
(0.000)\end{array}$ & $\begin{array}{c}-33.964^{* * *} \\
(0.000)\end{array}$ & $\begin{array}{c}-25.069^{* * *} \\
(0.000)\end{array}$ & $\begin{array}{c}-27.789^{* \star *} \\
(0.000)\end{array}$ & $\begin{array}{c}-25.914^{* * *} \\
(0.000)\end{array}$ & $\begin{array}{c}-42.757^{\star * *} \\
(0.000)\end{array}$ & $\begin{array}{c}-42.351^{* * *} \\
(0.000)\end{array}$ & $\begin{array}{c}-38.253^{\star * *} \\
(0.000)\end{array}$ & $\begin{array}{c}-39.274^{\star \star \star} \\
(0.000)\end{array}$ & $\begin{array}{c}-37.085^{\star \star \star} \\
(0.000)\end{array}$ \\
\hline
\end{tabular}




\begin{tabular}{|c|c|c|c|c|c|c|c|c|c|c|}
\hline Regulatory regime 8 & $\begin{array}{c}-29.822^{* * *} \\
(0.000)\end{array}$ & $\begin{array}{c}-33.238^{* * *} \\
(0.000)\end{array}$ & $\begin{array}{c}-22.788^{* * *} \\
(0.000)\end{array}$ & $\begin{array}{c}-25.344^{* * *} \\
(0.000)\end{array}$ & $\begin{array}{c}-23.378^{\star * *} \\
(0.000)\end{array}$ & $\begin{array}{c}-47.794^{* * *} \\
(0.000)\end{array}$ & $\begin{array}{c}-50.023^{* * *} \\
(0.000)\end{array}$ & $\begin{array}{c}-40.883^{* * *} \\
(0.000)\end{array}$ & $\begin{array}{c}-42.963^{* * *} \\
(0.000)\end{array}$ & $\begin{array}{c}-40.182^{* * *} \\
(0.000)\end{array}$ \\
\hline Regulatory regime 9 & $\begin{array}{c}-17.206^{* *} \\
(0.049)\end{array}$ & $\begin{array}{c}-18.010^{* *} \\
(0.034)\end{array}$ & $\begin{array}{l}-8.620 \\
(0.352)\end{array}$ & $\begin{array}{l}-8.136 \\
(0.427)\end{array}$ & $\begin{array}{c}-14.047^{*} \\
(0.094)\end{array}$ & $\begin{array}{c}-31.758^{* * *} \\
(0.005)\end{array}$ & $\begin{array}{c}-29.731^{\text {** }} \\
(0.013)\end{array}$ & $\begin{array}{c}-21.550^{*} \\
(0.097)\end{array}$ & $\begin{array}{r}-19.592 \\
(0.153)\end{array}$ & $\begin{array}{c}-25.702^{* *} \\
(0.048)\end{array}$ \\
\hline Regulatory regime 10 & $\begin{array}{c}-19.293^{* * *} \\
(0.001)\end{array}$ & $\begin{array}{c}-21.365^{\star \star *} \\
(0.000)\end{array}$ & $\begin{array}{c}-11.232^{*} \\
(0.059)\end{array}$ & $\begin{array}{c}-13.685^{\star *} \\
(0.028)\end{array}$ & $\begin{array}{c}-14.334^{* *} \\
(0.019)\end{array}$ & $\begin{array}{c}-26.483^{\star * *} \\
(0.000)\end{array}$ & $\begin{array}{c}-27.880^{* * *} \\
(0.000)\end{array}$ & $\begin{array}{c}-27.115^{\star * \star} \\
(0.000)\end{array}$ & $\begin{array}{c}-28.103^{* * *} \\
(0.000)\end{array}$ & $\begin{array}{c}-28.320^{* * *} \\
(0.000)\end{array}$ \\
\hline Joint stock company & & & $\begin{array}{l}8.518^{*} \\
(0.082)\end{array}$ & $\begin{array}{l}9.090^{*} \\
(0.071)\end{array}$ & $\begin{array}{c}5.902 \\
(0.228)\end{array}$ & & & $\begin{array}{c}6.108 \\
(0.316)\end{array}$ & $\begin{array}{c}6.617 \\
(0.294)\end{array}$ & $\begin{array}{c}6.678 \\
(0.266)\end{array}$ \\
\hline Limited liability company & & & $\begin{array}{c}8.097 \\
(0.116)\end{array}$ & $\begin{array}{c}7.422 \\
(0.154)\end{array}$ & $\begin{array}{c}6.259 \\
(0.196)\end{array}$ & & & $\begin{array}{l}14.078^{*} \\
(0.088)\end{array}$ & $\begin{array}{l}13.652 \\
(0.118)\end{array}$ & $\begin{array}{c}16.023^{* *} \\
(0.039)\end{array}$ \\
\hline Foreign company & & & $\begin{array}{c}17.480^{* * *} \\
(0.002)\end{array}$ & $\begin{array}{c}16.654^{* * *} \\
(0.009)\end{array}$ & $\begin{array}{c}13.381^{* *} \\
(0.021)\end{array}$ & & & $\begin{array}{l}13.619^{*} \\
(0.069)\end{array}$ & $\begin{array}{l}12.658 \\
(0.101)\end{array}$ & $\begin{array}{l}13.719^{*} \\
(0.053)\end{array}$ \\
\hline Financial investor & & & $\begin{array}{c}24.622^{* * *} \\
(0.000)\end{array}$ & $\begin{array}{c}22.412^{* * *} \\
(0.000)\end{array}$ & $\begin{array}{c}24.434^{* * *} \\
(0.000)\end{array}$ & & & $\begin{array}{c}16.794^{* *} \\
(0.033)\end{array}$ & $\begin{array}{l}15.586^{*} \\
(0.085)\end{array}$ & $\begin{array}{c}16.383^{* *} \\
(0.041)\end{array}$ \\
\hline Group & & & $\begin{array}{l}-3.079 \\
(0.759)\end{array}$ & $\begin{array}{c}0.988 \\
(0.916)\end{array}$ & $\begin{array}{l}-0.788 \\
(0.927)\end{array}$ & & & $\begin{array}{l}-1.701 \\
(0.921)\end{array}$ & $\begin{array}{c}1.117 \\
(0.951)\end{array}$ & $\begin{array}{c}1.816 \\
(0.904)\end{array}$ \\
\hline SIF & & & $\begin{array}{l}14.239 \\
(0.227)\end{array}$ & $\begin{array}{l}14.201 \\
(0.174)\end{array}$ & $\begin{array}{l}12.829 \\
(0.250)\end{array}$ & & & $\begin{array}{l}15.330 \\
(0.334)\end{array}$ & $\begin{array}{l}13.477 \\
(0.354)\end{array}$ & $\begin{array}{l}16.091 \\
(0.301)\end{array}$ \\
\hline $\mathrm{N}$ & 1,696 & 1,592 & 1,696 & 1,586 & 1,696 & 1,696 & 1,592 & 1,696 & 1,586 & 1,696 \\
\hline Sum of absolute deviations & $301,663.9$ & $287,993.2$ & $300,700.4$ & $286,967.7$ & $300,569.7$ & $391,966.4$ & $376,326.8$ & $391,600.0$ & $375,464.6$ & $391,229.4$ \\
\hline Sum of raw deviations & $406,242.2$ & $389,710.6$ & $406,242.2$ & $389,503.9$ & $406,242.2$ & $499,076.7$ & $481,116.1$ & $499,076.7$ & $480,614.4$ & $499,076.7$ \\
\hline Pseudo-R2 & 0.257 & 0.261 & 0.260 & 0.263 & 0.260 & 0.215 & 0.218 & 0.215 & 0.219 & 0.216 \\
\hline HO: Regimes jointly zero & $6.585^{\star * \star}$ & $6.518^{* * *}$ & $3.959^{* * *}$ & $4.382^{* * *}$ & $3.447^{\star \star *}$ & $9.283^{* * *}$ & $7.592^{\star \star *}$ & $4.487^{\star * *}$ & $4.333^{* \star *}$ & $4.543^{* \star *}$ \\
\hline HO: Regimes same effect & $3.449^{* * *}$ & $3.431^{* * *}$ & $1.900^{*}$ & $1.956^{\star *}$ & 1.488 & $4.849^{* * *}$ & $4.346^{* * *}$ & $2.092^{* *}$ & $2.280^{* *}$ & $2.180^{\star *}$ \\
\hline
\end{tabular}


Table 7: Privatization premium benchmark and initial bid premium (1998--2004 sub-sample)

\begin{tabular}{|c|c|c|c|c|c|c|}
\hline Independent variable & $(1)$ & $(2)$ & $(3)$ & $(4)$ & $(5)$ & (6) \\
\hline Privatization premium benchmark & $\begin{array}{l}0.039^{* *} \\
(0.050)\end{array}$ & $\begin{array}{l}0.034^{*} \\
(0.065)\end{array}$ & $\begin{array}{l}0.042^{* *} \\
(0.013)\end{array}$ & $\begin{array}{l}0.033^{* *} \\
(0.016)\end{array}$ & $\begin{array}{l}0.037^{\star *} \\
(0.018)\end{array}$ & $\begin{array}{l}0.029^{\star *} \\
(0.043)\end{array}$ \\
\hline 52-week High & $\begin{array}{l}1.049^{\star * *} \\
(0.000)\end{array}$ & $\begin{array}{l}1.066^{* * *} \\
(0.000)\end{array}$ & $\begin{array}{l}1.066^{* * *} \\
(0.000)\end{array}$ & $\begin{array}{l}1.092^{* * *} \\
(0.000)\end{array}$ & $\begin{array}{l}1.083^{* * *} \\
(0.000)\end{array}$ & $\begin{array}{l}1.090^{* * *} \\
(0.000)\end{array}$ \\
\hline Financial dilution & $\begin{array}{c}1.401 \\
(0.873)\end{array}$ & $\begin{array}{c}2.063 \\
(0.798)\end{array}$ & $\begin{array}{c}3.624 \\
(0.650)\end{array}$ & $\begin{array}{c}1.652 \\
(0.845)\end{array}$ & $\begin{array}{c}1.939 \\
(0.798)\end{array}$ & $\begin{array}{l}-0.300 \\
(0.968)\end{array}$ \\
\hline Equity change & $\begin{array}{c}3.887 \\
(0.502)\end{array}$ & $\begin{array}{c}2.430 \\
(0.631)\end{array}$ & $\begin{array}{c}3.941 \\
(0.346)\end{array}$ & $\begin{array}{c}1.293 \\
(0.783)\end{array}$ & $\begin{array}{c}1.464 \\
(0.772)\end{array}$ & $\begin{array}{l}-0.412 \\
(0.932)\end{array}$ \\
\hline Direct toehold & $\begin{array}{c}0.014 \\
(0.837)\end{array}$ & & $\begin{array}{l}-0.068 \\
(0.389)\end{array}$ & & & \\
\hline Indirect toehold & & $\begin{array}{c}0.030 \\
(0.611)\end{array}$ & & $\begin{array}{l}-0.091 \\
(0.248)\end{array}$ & & \\
\hline Zero toehold & & & $\begin{array}{l}-5.419 \\
(0.358)\end{array}$ & $\begin{array}{l}-3.944 \\
(0.421)\end{array}$ & & \\
\hline Direct toehold $\in(0 ; 33 \%)$ & & & & & $\begin{array}{c}1.964 \\
(0.735)\end{array}$ & \\
\hline Direct toehold $\in[33 \% ; 50 \%)$ & & & & & $\begin{array}{c}0.248 \\
(0.972)\end{array}$ & \\
\hline Direct toehold $\in[50 \% ; 90 \%)$ & & & & & $\begin{array}{l}7.507 \\
(0.316)\end{array}$ & \\
\hline Direct toehold $\in[90 \% ; 100 \%)$ & & & & & $\begin{array}{l}-7.918 \\
(0.189)\end{array}$ & \\
\hline Indirect toehold $\in(0 ; 33 \%)$ & & & & & & $\begin{array}{c}0.131 \\
(0.983)\end{array}$ \\
\hline Indirect toehold $\in[33 \% ; 50 \%)$ & & & & & & $\begin{array}{l}-5.140 \\
(0.447)\end{array}$ \\
\hline Indirect toehold $\in[50 \% ; 90 \%)$ & & & & & & $\begin{array}{c}7.580 \\
(0.274)\end{array}$ \\
\hline Indirect toehold $\in[90 \% ; 100 \%)$ & & & & & & $\begin{array}{c}-9.336^{*} \\
(0.091)\end{array}$ \\
\hline AVAS foothold & & & $\begin{array}{l}-9.087 \\
(0.104)\end{array}$ & $\begin{array}{c}-11.724^{\star \star} \\
(0.027)\end{array}$ & $\begin{array}{l}-8.162 \\
(0.116)\end{array}$ & $\begin{array}{l}-6.725 \\
(0.161)\end{array}$ \\
\hline Regulatory regime 2 & $\begin{array}{c}-25.101^{*} \\
(0.075)\end{array}$ & $\begin{array}{c}-25.063^{*} \\
(0.079)\end{array}$ & $\begin{array}{c}-14.790 \\
(0.161)\end{array}$ & $\begin{array}{c}-13.598 \\
(0.211)\end{array}$ & $\begin{array}{c}-14.133 \\
(0.208)\end{array}$ & $\begin{array}{c}-13.300 \\
(0.305)\end{array}$ \\
\hline Regulatory regime 3 & $\begin{array}{c}7.364 \\
(0.794)\end{array}$ & $\begin{array}{l}30.024 \\
(0.261)\end{array}$ & $\begin{array}{l}17.395 \\
(0.472)\end{array}$ & $\begin{array}{l}20.065 \\
(0.460)\end{array}$ & $\begin{array}{l}11.593 \\
(0.692)\end{array}$ & $\begin{array}{l}24.835 \\
(0.437)\end{array}$ \\
\hline Regulatory regime 4 & $\begin{array}{c}68.903^{* *} \\
(0.029)\end{array}$ & $\begin{array}{c}69.510^{* *} \\
(0.030)\end{array}$ & $\begin{array}{c}56.213^{* *} \\
(0.034)\end{array}$ & $\begin{array}{c}54.842^{* *} \\
(0.045)\end{array}$ & $\begin{array}{c}62.103^{* *} \\
(0.046)\end{array}$ & $\begin{array}{l}61.360^{*} \\
(0.051)\end{array}$ \\
\hline Regulatory regime 5 & $\begin{array}{c}-11.110 \\
(0.489)\end{array}$ & $\begin{array}{r}-11.037 \\
(0.454)\end{array}$ & $\begin{array}{c}0.855 \\
(0.960)\end{array}$ & $\begin{array}{c}0.063 \\
(0.997)\end{array}$ & $\begin{array}{c}1.740 \\
(0.924)\end{array}$ & $\begin{array}{l}-2.525 \\
(0.852)\end{array}$ \\
\hline Regulatory regime 6 & $\begin{array}{c}-14.547^{* *} \\
(0.022)\end{array}$ & $\begin{array}{c}-14.750^{* *} \\
(0.030)\end{array}$ & $\begin{array}{c}-10.808 \\
(0.134)\end{array}$ & $\begin{array}{c}-10.340 \\
(0.169)\end{array}$ & $\begin{array}{l}-8.153 \\
(0.248)\end{array}$ & $\begin{array}{l}-8.269 \\
(0.173)\end{array}$ \\
\hline Regulatory regime 7 & $\begin{array}{c}-31.497^{* * *} \\
(0.000)\end{array}$ & $\begin{array}{c}-31.437^{* * *} \\
(0.000)\end{array}$ & $\begin{array}{c}-21.826^{* * *} \\
(0.000)\end{array}$ & $\begin{array}{c}-21.499^{* * *} \\
(0.000)\end{array}$ & $\begin{array}{c}-20.022^{* * *} \\
(0.000)\end{array}$ & $\begin{array}{c}-19.457^{* * *} \\
(0.001)\end{array}$ \\
\hline Regulatory regime 8 & $\begin{array}{c}-27.269^{* * *} \\
(0.008)\end{array}$ & $\begin{array}{c}-29.795^{* * *} \\
(0.000)\end{array}$ & $\begin{array}{c}-16.206^{*} \\
(0.087)\end{array}$ & $\begin{array}{c}-21.200^{* *} \\
(0.027)\end{array}$ & $\begin{array}{c}-14.686 \\
(0.175)\end{array}$ & $\begin{array}{c}-17.814^{* *} \\
(0.045)\end{array}$ \\
\hline Joint stock company & & & $\begin{array}{l}11.333^{* *} \\
(0.035)\end{array}$ & $\begin{array}{c}18.681^{* * *} \\
(0.004)\end{array}$ & $\begin{array}{c}13.705^{* *} \\
(0.023)\end{array}$ & $\begin{array}{c}19.409^{* * *} \\
(0.001)\end{array}$ \\
\hline Limited liability company & & & $\begin{array}{c}13.389^{* *} \\
(0.041)\end{array}$ & $\begin{array}{c}19.101^{* * *} \\
(0.007)\end{array}$ & $\begin{array}{c}12.564^{* *} \\
(0.036)\end{array}$ & $\begin{array}{c}16.645^{* *} \\
(0.017)\end{array}$ \\
\hline Foreign company & & & $\begin{array}{c}26.427^{* * *} \\
(0.000)\end{array}$ & $\begin{array}{c}29.837^{\star * *} \\
(0.000)\end{array}$ & $\begin{array}{c}24.007^{* * *} \\
(0.000)\end{array}$ & $\begin{array}{c}26.589^{* * *} \\
(0.000)\end{array}$ \\
\hline Financial investor & & & $\begin{array}{c}27.740^{* * *} \\
(0.000)\end{array}$ & $\begin{array}{c}29.395^{\star * *} \\
(0.000)\end{array}$ & $\begin{array}{c}26.952^{* * *} \\
(0.000)\end{array}$ & $\begin{array}{c}30.104^{* * *} \\
(0.000)\end{array}$ \\
\hline Group & & & $\begin{array}{l}10.748 \\
(0.588)\end{array}$ & $\begin{array}{c}9.812 \\
(0.540)\end{array}$ & $\begin{array}{c}4.172 \\
(0.818)\end{array}$ & $\begin{array}{c}6.586 \\
(0.553)\end{array}$ \\
\hline SIF & & & $\begin{array}{l}16.566 \\
(0.237) \\
\end{array}$ & $\begin{array}{l}19.234^{*} \\
(0.070)\end{array}$ & $\begin{array}{c}20.746^{* *} \\
(0.033)\end{array}$ & $\begin{array}{c}22.918^{* *} \\
(0.043)\end{array}$ \\
\hline $\mathrm{N}$ & 1,355 & 1,256 & 1,355 & 1,251 & 1,355 & 1,256 \\
\hline Sum of absolute deviations & $99,357.5$ & $92,099.4$ & $98,106.7$ & $90,637.9$ & $97,927.5$ & $90,594.0$ \\
\hline Sum of raw deviations & $186,349.4$ & $176,416.9$ & $186,349.4$ & $176,297.4$ & $186,349.4$ & $176,416.9$ \\
\hline Pseudo-R2 & 0.467 & 0.478 & 0.474 & 0.486 & 0.474 & 0.486 \\
\hline H0: Regimes jointly zero & $6.071^{* * *}$ & $5.830^{\star * *}$ & $3.997^{* * *}$ & $5.269^{* * *}$ & $2.853^{* * *}$ & $2.745^{\star * \star}$ \\
\hline
\end{tabular}


H0: Regimes same effect

$3.647^{* * *}$

$4.362^{* * *}$

$2.721^{* *}$

$2.292^{* *}$

$1.860^{*}$

$2.150^{* *}$

Note: the median regression coefficient estimates reported in this table are based on bootstrap standard errors computed using 1,000 replications; the reported pseudo-R2 is calculated as 1 - [sum of the weighted deviations about estimated median / sum of weighted deviations about raw median]; constant included but not reported 
Table 8: Bidder paid 52-week high, short-term toehold, insiders, and initial bid premium (2006--2012 sub-sample)

\begin{tabular}{|c|c|c|c|c|c|c|}
\hline Independent variable & $(1)$ & $(2)$ & (3) & $(4)$ & $(5)$ & (6) \\
\hline Bidder paid 52-week High & $\begin{array}{c}-23.402^{\star \star \star} \\
(0.008)\end{array}$ & $\begin{array}{c}-26.448^{\star \star \star} \\
(0.002)\end{array}$ & $\begin{array}{c}-24.393 \\
(0.294)\end{array}$ & $\begin{array}{c}-24.719^{* \star \star} \\
(0.005)\end{array}$ & $\begin{array}{c}-23.262 \\
(0.270)\end{array}$ & $\begin{array}{c}-23.928^{* * *} \\
(0.010)\end{array}$ \\
\hline Short-term toehold & $\begin{array}{l}-0.024 \\
(0.911)\end{array}$ & $\begin{array}{l}-0.086 \\
(0.642)\end{array}$ & $\begin{array}{l}-0.108 \\
(0.670)\end{array}$ & $\begin{array}{l}-0.094 \\
(0.666)\end{array}$ & $\begin{array}{l}-0.114 \\
(0.589)\end{array}$ & $\begin{array}{l}-0.096 \\
(0.621)\end{array}$ \\
\hline Other insiders & $\begin{array}{c}2.160 \\
(0.809)\end{array}$ & $\begin{array}{c}4.092 \\
(0.602)\end{array}$ & $\begin{array}{c}4.018 \\
(0.615)\end{array}$ & $\begin{array}{c}6.178 \\
(0.476)\end{array}$ & $\begin{array}{c}4.497 \\
(0.590)\end{array}$ & $\begin{array}{c}1.896 \\
(0.804)\end{array}$ \\
\hline 52-week High & $\begin{array}{c}1.029^{* * *} \\
(0.000)\end{array}$ & $\begin{array}{c}1.035^{\star * *} \\
(0.000)\end{array}$ & $\begin{array}{l}1.008^{* * *} \\
(0.000)\end{array}$ & $\begin{array}{l}1.014^{* * *} \\
(0.000)\end{array}$ & $\begin{array}{l}1.012^{* * *} \\
(0.000)\end{array}$ & $\begin{array}{c}1.006^{* * *} \\
(0.000)\end{array}$ \\
\hline Financial dilution & $\begin{array}{l}-3.510 \\
(0.773)\end{array}$ & $\begin{array}{c}1.472 \\
(0.879)\end{array}$ & $\begin{array}{l}-6.412 \\
(0.585)\end{array}$ & $\begin{array}{l}-3.406 \\
(0.774)\end{array}$ & $\begin{array}{l}-6.876 \\
(0.619)\end{array}$ & $\begin{array}{l}-6.073 \\
(0.650)\end{array}$ \\
\hline Equity change & $\begin{array}{c}0.298 \\
(0.971)\end{array}$ & $\begin{array}{l}-0.373 \\
(0.969)\end{array}$ & $\begin{array}{c}4.295 \\
(0.727)\end{array}$ & $\begin{array}{l}-4.849 \\
(0.684)\end{array}$ & $\begin{array}{c}7.828 \\
(0.490)\end{array}$ & $\begin{array}{c}1.197 \\
(0.904)\end{array}$ \\
\hline Direct toehold & $\begin{array}{c}0.013 \\
(0.895)\end{array}$ & & $\begin{array}{l}-0.041 \\
(0.792)\end{array}$ & & & \\
\hline Indirect toehold & & $\begin{array}{c}0.138 \\
(0.301)\end{array}$ & & $\begin{array}{c}0.204 \\
(0.202)\end{array}$ & & \\
\hline Zero toehold & & & $\begin{array}{r}-17.251 \\
(0.617)\end{array}$ & $\begin{array}{c}1.512 \\
(0.978)\end{array}$ & & \\
\hline Direct toehold $\in(0 ; 33 \%)$ & & & & & $\begin{array}{c}8.422 \\
(0.788)\end{array}$ & \\
\hline Direct toehold $\in[33 \% ; 50 \%)$ & & & & & $\begin{array}{l}28.339 \\
(0.388)\end{array}$ & \\
\hline Direct toehold $\in[50 \% ; 90 \%)$ & & & & & $\begin{array}{l}12.833 \\
(0.693)\end{array}$ & \\
\hline Direct toehold $\in[90 \% ; 100 \%)$ & & & & & $\begin{array}{l}12.855 \\
(0.692)\end{array}$ & \\
\hline Indirect toehold $\in(0 ; 33 \%)$ & & & & & & $\begin{array}{l}-8.392 \\
(0.923)\end{array}$ \\
\hline Indirect toehold $\in[33 \% ; 50 \%)$ & & & & & & $\begin{array}{l}24.234 \\
(0.782)\end{array}$ \\
\hline Indirect toehold $\in[50 \% ; 90 \%)$ & & & & & & $\begin{array}{l}16.246 \\
(0.853)\end{array}$ \\
\hline Indirect toehold $\in[90 \% ; 100 \%)$ & & & & & & $\begin{array}{l}17.263 \\
(0.845)\end{array}$ \\
\hline AVAS foothold & & & $\begin{array}{l}-5.873 \\
(0.756)\end{array}$ & $\begin{array}{l}-8.909 \\
(0.655)\end{array}$ & $\begin{array}{l}-5.302 \\
(0.664)\end{array}$ & $\begin{array}{l}-4.594 \\
(0.819)\end{array}$ \\
\hline Joint stock company & & & $\begin{array}{l}-5.377 \\
(0.672)\end{array}$ & $\begin{array}{r}-12.955 \\
(0.310)\end{array}$ & $\begin{array}{l}-4.573 \\
(0.708)\end{array}$ & $\begin{array}{l}-9.419 \\
(0.397)\end{array}$ \\
\hline Limited liability company & & & $\begin{array}{l}-8.655 \\
(0.359)\end{array}$ & $\begin{array}{c}-15.919 \\
(0.102)\end{array}$ & $\begin{array}{l}-7.729 \\
(0.426)\end{array}$ & $\begin{array}{c}-14.929 \\
(0.105)\end{array}$ \\
\hline Foreign company & & & $\begin{array}{c}-15.911^{*} \\
(0.072)\end{array}$ & $\begin{array}{c}-21.194^{* *} \\
(0.042)\end{array}$ & $\begin{array}{r}-15.191 \\
(0.137)\end{array}$ & $\begin{array}{c}-21.435^{*} \\
(0.051)\end{array}$ \\
\hline Financial investor & & & $\begin{array}{c}-16.685 \\
(0.361)\end{array}$ & $\begin{array}{c}-12.615 \\
(0.472)\end{array}$ & $\begin{array}{l}-7.681 \\
(0.699)\end{array}$ & $\begin{array}{r}-25.757 \\
(0.242)\end{array}$ \\
\hline Group & & & $\begin{array}{c}-26.779 \\
(0.213)\end{array}$ & $\begin{array}{c}-15.063 \\
(0.413)\end{array}$ & $\begin{array}{c}-17.583 \\
(0.355)\end{array}$ & $\begin{array}{l}-5.354 \\
(0.771)\end{array}$ \\
\hline SIF & & & $\begin{array}{c}9.297 \\
(0.762) \\
\end{array}$ & $\begin{array}{l}-2.354 \\
(0.929)\end{array}$ & $\begin{array}{l}15.446 \\
(0.546)\end{array}$ & $\begin{array}{c}6.162 \\
(0.820)\end{array}$ \\
\hline $\mathrm{N}$ & 277 & 273 & 277 & 273 & 277 & 273 \\
\hline Sum of absolute deviations & $17,088.2$ & $16,919.9$ & $16,874.6$ & $16,722.8$ & $16,798.9$ & $16,582.4$ \\
\hline Sum of raw deviations & $28,405.9$ & $27,852.0$ & $28,405.9$ & $27,852.0$ & $28,405.9$ & $27,852.0$ \\
\hline Pseudo-R2 & 0.398 & 0.393 & 0.406 & 0.400 & 0.409 & 0.405 \\
\hline
\end{tabular}

Note: the median regression coefficient estimates reported in this table are based on bootstrap standard errors computed using 1,000 replications; the reported pseudo-R2 is calculated as $1-$ [sum of the weighted deviations about estimated median / sum of weighted deviations about raw median]; constant included but not reported 
Table 9: Bid outcome - Generalized Linear Model (GLM) regressions

\begin{tabular}{|c|c|c|c|c|c|c|c|}
\hline Independent variable & $(1)$ & $(2)$ & $(3)$ & $(4)$ & (5) & $(6)$ & $(7)$ \\
\hline Final premium & $\begin{array}{l}0.023^{\star *} \\
(0.046)\end{array}$ & $\begin{array}{c}0.029^{* * *} \\
(0.010)\end{array}$ & $\begin{array}{c}0.024^{* * *} \\
(0.002)\end{array}$ & & & & \\
\hline Direct toehold & & & & $\begin{array}{c}-1.265^{\star * *} \\
(0.000)\end{array}$ & & & \\
\hline Indirect toehold & & & & & & $\begin{array}{c}-1.266^{* * *} \\
(0.000)\end{array}$ & \\
\hline Direct toehold $\in(0 ; 33 \%)$ & & & & & $\begin{array}{c}-0.284^{* *} \\
(0.013)\end{array}$ & & \\
\hline Direct toehold $\in[33 \% ; 50 \%)$ & & & & & $\begin{array}{c}-0.409^{* * *} \\
(0.002)\end{array}$ & & \\
\hline Direct toehold $\in[50 \% ; 90 \%)$ & & & & & $\begin{array}{c}-0.576^{* * *} \\
(0.000)\end{array}$ & & \\
\hline Direct toehold $\in[90 \% ; 100 \%]$ & & & & & $\begin{array}{c}-1.777^{* * *} \\
(0.000)\end{array}$ & & \\
\hline Indirect toehold $\in(0 ; 33 \%)$ & & & & & & & $\begin{array}{c}-0.194 \\
(0.142)\end{array}$ \\
\hline Indirect toehold $\in[33 \% ; 50 \%)$ & & & & & & & $\begin{array}{c}-0.281^{*} \\
(0.055)\end{array}$ \\
\hline Indirect toehold $\in[50 \% ; 90 \%)$ & & & & & & & $\begin{array}{c}-0.420^{* * *} \\
(0.001)\end{array}$ \\
\hline Indirect toehold $\in[90 \% ; 100 \%)$ & & & & & & & $\begin{array}{c}-1.813^{* * *} \\
(0.000)\end{array}$ \\
\hline Novel control & & & $\begin{array}{c}1.428^{* \star *} \\
(0.000)\end{array}$ & & & & \\
\hline 52-week High & & & & $\begin{array}{c}0.043^{* * *} \\
(0.009)\end{array}$ & $\begin{array}{c}0.056^{\star * *} \\
(0.001)\end{array}$ & $\begin{array}{l}0.041^{\star *} \\
(0.016)\end{array}$ & $\begin{array}{c}0.059 * * * \\
(0.001)\end{array}$ \\
\hline Price revision & $\begin{array}{c}0.720^{* * *} \\
(0.000)\end{array}$ & $\begin{array}{c}0.585^{\star * *} \\
(0.000)\end{array}$ & $\begin{array}{c}0.538^{* * *} \\
(0.000)\end{array}$ & $\begin{array}{c}0.443^{* * *} \\
(0.000)\end{array}$ & $\begin{array}{c}0.394^{* * *} \\
(0.000)\end{array}$ & $\begin{array}{c}0.375^{\star * *} \\
(0.001)\end{array}$ & $\begin{array}{c}0.309^{* * *} \\
(0.006)\end{array}$ \\
\hline Period extended & $\begin{array}{c}0.059 \\
(0.635)\end{array}$ & $\begin{array}{c}0.035 \\
(0.789)\end{array}$ & $\begin{array}{l}0.269^{*} \\
(0.063)\end{array}$ & $\begin{array}{l}-0.087 \\
(0.518)\end{array}$ & $\begin{array}{l}-0.107 \\
(0.420)\end{array}$ & $\begin{array}{l}-0.067 \\
(0.623)\end{array}$ & $\begin{array}{l}-0.100 \\
(0.458)\end{array}$ \\
\hline Rival & $\begin{array}{c}-0.991^{* * *} \\
(0.000)\end{array}$ & $\begin{array}{c}-0.926^{* * *} \\
(0.000)\end{array}$ & $\begin{array}{c}0.324 \\
(0.891)\end{array}$ & $\begin{array}{c}-1.135^{* * *} \\
(0.000)\end{array}$ & $\begin{array}{c}-1.121^{* * *} \\
(0.000)\end{array}$ & $\begin{array}{c}-1.226^{\star * *} \\
(0.000)\end{array}$ & $\begin{array}{c}-1.178^{* * *} \\
(0.000)\end{array}$ \\
\hline Financial dilution & $\begin{array}{c}0.480^{* * *} \\
(0.001)\end{array}$ & $\begin{array}{l}0.373^{* *} \\
(0.020)\end{array}$ & $\begin{array}{c}0.139 \\
(0.889)\end{array}$ & $\begin{array}{c}0.009 \\
(0.952)\end{array}$ & $\begin{array}{l}-0.130 \\
(0.426)\end{array}$ & $\begin{array}{c}0.012 \\
(0.939)\end{array}$ & $\begin{array}{l}-0.192 \\
(0.250)\end{array}$ \\
\hline Regulatory regime 2 & & $\begin{array}{l}-0.050 \\
(0.817)\end{array}$ & $\begin{array}{l}-0.227 \\
(0.976)\end{array}$ & $\begin{array}{c}0.029 \\
(0.890)\end{array}$ & $\begin{array}{c}0.048 \\
(0.825)\end{array}$ & $\begin{array}{l}-0.065 \\
(0.769)\end{array}$ & $\begin{array}{c}0.010 \\
(0.965)\end{array}$ \\
\hline Regulatory regime 3 & & $\begin{array}{l}-0.066 \\
(0.847)\end{array}$ & $\begin{array}{c}-0.137^{* *} \\
(0.022)\end{array}$ & $\begin{array}{l}-0.285 \\
(0.429)\end{array}$ & $\begin{array}{l}-0.260 \\
(0.450)\end{array}$ & $\begin{array}{l}-0.251 \\
(0.562)\end{array}$ & $\begin{array}{l}-0.283 \\
(0.473)\end{array}$ \\
\hline Regulatory regime 4 & & $\begin{array}{c}0.331 \\
(0.779)\end{array}$ & $\begin{array}{l}-0.312 \\
(0.992)\end{array}$ & $\begin{array}{c}0.345 \\
(0.733)\end{array}$ & $\begin{array}{c}0.203 \\
(0.850)\end{array}$ & $\begin{array}{c}0.180 \\
(0.862)\end{array}$ & $\begin{array}{c}0.048 \\
(0.965)\end{array}$ \\
\hline Regulatory regime 5 & & $\begin{array}{c}0.019 \\
(0.948)\end{array}$ & $\begin{array}{l}-0.303 \\
(0.180)\end{array}$ & $\begin{array}{c}0.100 \\
(0.695)\end{array}$ & $\begin{array}{c}0.211 \\
(0.400)\end{array}$ & $\begin{array}{c}0.143 \\
(0.578)\end{array}$ & $\begin{array}{c}0.347 \\
(0.170)\end{array}$ \\
\hline Regulatory regime 6 & & $\begin{array}{c}0.214 \\
(0.130)\end{array}$ & $\begin{array}{l}0.072^{\star *} \\
(0.030)\end{array}$ & $\begin{array}{l}0.291^{* *} \\
(0.041)\end{array}$ & $\begin{array}{l}0.362^{* *} \\
(0.012)\end{array}$ & $\begin{array}{l}0.279^{*} \\
(0.051)\end{array}$ & $\begin{array}{c}0.391^{* * *} \\
(0.007)\end{array}$ \\
\hline Regulatory regime 7 & & $\begin{array}{c}-0.394^{* * *} \\
(0.001)\end{array}$ & $\begin{array}{c}-0.497^{\star * *} \\
(0.006)\end{array}$ & $\begin{array}{l}-0.161 \\
(0.180)\end{array}$ & $\begin{array}{c}0.028 \\
(0.823)\end{array}$ & $\begin{array}{c}-0.223^{*} \\
(0.070)\end{array}$ & $\begin{array}{c}0.095 \\
(0.468)\end{array}$ \\
\hline Regulatory regime 8 & & $\begin{array}{c}-0.635^{\star * *} \\
(0.000)\end{array}$ & $\begin{array}{c}-0.871^{* *} \\
(0.012)\end{array}$ & $\begin{array}{c}-0.388^{* *} \\
(0.024)\end{array}$ & $\begin{array}{c}-0.314^{*} \\
(0.063)\end{array}$ & $\begin{array}{c}-0.405^{\star *} \\
(0.024)\end{array}$ & $\begin{array}{l}-0.202 \\
(0.254)\end{array}$ \\
\hline Regulatory regime 9 & & $\begin{array}{c}-0.940^{* * *} \\
(0.000)\end{array}$ & $\begin{array}{c}-0.785^{\star * *} \\
(0.000)\end{array}$ & $\begin{array}{c}-0.794^{* * *} \\
(0.002)\end{array}$ & $\begin{array}{c}-0.849^{* * *} \\
(0.001)\end{array}$ & $\begin{array}{c}-0.782^{* * *} \\
(0.002)\end{array}$ & $\begin{array}{c}-0.876^{* * *} \\
(0.000)\end{array}$ \\
\hline Regulatory regime 10 & & $\begin{array}{c}-0.810^{* * *} \\
(0.000)\end{array}$ & $\begin{array}{c}-0.538^{* * *} \\
(0.000)\end{array}$ & $\begin{array}{c}-0.542^{* * *} \\
(0.000)\end{array}$ & $\begin{array}{c}-0.597^{* * *} \\
(0.000)\end{array}$ & $\begin{array}{c}-0.526^{* \star *} \\
(0.000)\end{array}$ & $\begin{array}{c}-0.542^{* * *} \\
(0.000)\end{array}$ \\
\hline Joint stock company & & $\begin{array}{c}0.058 \\
(0.611)\end{array}$ & $\begin{array}{c}0.008 \\
(0.248)\end{array}$ & $\begin{array}{l}0.216^{*} \\
(0.061)\end{array}$ & $\begin{array}{c}0.185 \\
(0.107)\end{array}$ & $\begin{array}{c}0.171 \\
(0.149)\end{array}$ & $\begin{array}{c}0.133 \\
(0.260)\end{array}$ \\
\hline Limited liability company & & $\begin{array}{c}0.118 \\
(0.239)\end{array}$ & $\begin{array}{c}0.083 \\
(0.489)\end{array}$ & $\begin{array}{c}0.302^{* * *} \\
(0.003)\end{array}$ & $\begin{array}{l}0.249^{* *} \\
(0.015)\end{array}$ & $\begin{array}{l}0.198^{*} \\
(0.059)\end{array}$ & $\begin{array}{c}0.151 \\
(0.151)\end{array}$ \\
\hline Foreign company & & $\begin{array}{c}0.562^{* * *} \\
(0.000)\end{array}$ & $\begin{array}{c}0.366^{* * *} \\
(0.000)\end{array}$ & $\begin{array}{c}0.786^{* * *} \\
(0.000)\end{array}$ & $\begin{array}{c}0.809^{* * *} \\
(0.000)\end{array}$ & $\begin{array}{c}0.727^{* * *} \\
(0.000)\end{array}$ & $\begin{array}{c}0.769^{* * *} \\
(0.000)\end{array}$ \\
\hline Financial investor & & $\begin{array}{c}0.080 \\
(0.598)\end{array}$ & $\begin{array}{c}0.108 \\
(0.286)\end{array}$ & $\begin{array}{c}0.160 \\
(0.301)\end{array}$ & $\begin{array}{c}0.120 \\
(0.426)\end{array}$ & $\begin{array}{c}0.182 \\
(0.289)\end{array}$ & $\begin{array}{c}0.061 \\
(0.712)\end{array}$ \\
\hline Group & & $\begin{array}{c}0.146 \\
(0.618)\end{array}$ & $\begin{array}{c}0.114 \\
(0.541)\end{array}$ & $\begin{array}{c}0.300 \\
(0.305)\end{array}$ & $\begin{array}{c}0.298 \\
(0.321)\end{array}$ & $\begin{array}{c}0.256 \\
(0.388)\end{array}$ & $\begin{array}{c}0.234 \\
(0.451)\end{array}$ \\
\hline SIF & & $\begin{array}{c}0.184 \\
(0.512)\end{array}$ & $\begin{array}{c}0.202 \\
(0.950)\end{array}$ & $\begin{array}{l}0.491^{*} \\
(0.085)\end{array}$ & $\begin{array}{l}0.489^{*} \\
(0.097)\end{array}$ & $\begin{array}{c}0.355 \\
(0.212)\end{array}$ & $\begin{array}{c}0.319 \\
(0.283)\end{array}$ \\
\hline
\end{tabular}




\begin{tabular}{lccccccc} 
Constant & $-0.647^{* * *}$ & $-0.451^{* * *}$ & $-0.554^{* * *}$ & $-0.291^{* * *}$ & $-0.311^{* *}$ & -0.113 & $-0.263^{*}$ \\
& $(0.000)$ & $(0.000)$ & $(0.000)$ & $(0.002)$ & $(0.013)$ & $(0.275)$ & $(0.057)$ \\
\hline $\mathrm{N}$ & 1,693 & 1,693 & 1,208 & 1,706 & 1,706 & 1,602 & 1,602 \\
Log-likelihood & -901.668 & -876.017 & -581.592 & -863.595 & -853.280 & -811.340 & -794.480 \\
Chi2 & $82.2^{* * *}$ & $193.6^{* * *}$ & $451.9^{* * *}$ & $270.5^{* * *}$ & $335.8^{* * *}$ & $277.5^{* * *}$ & $367.1^{* * *}$ \\
AIC & $1,815.3$ & $1,794.0$ & $1,207.1$ & $1,771.1$ & $1,756.5$ & $1,666.6$ & $1,638.9$ \\
BIC & $1,847.9$ & $1,908.1$ & $1,319.3$ & $1,890.9$ & $1,892.6$ & $1,785.0$ & $1,773.4$ \\
Dispersion (scaled) & 0.619 & 0.594 & 0.474 & 0.573 & 0.562 & 0.576 & 0.555 \\
Pearson dispersion & 0.529 & 0.518 & 0.427 & 0.507 & 0.494 & 0.505 & 0.486 \\
H0: Regimes jointly zero & - & $72.304^{* * *}$ & $47.959^{* * *}$ & $38.626^{* * *}$ & $46.915^{* * *}$ & $36.260^{* * *}$ & $44.655^{* * *}$ \\
H0: Regimes same effect & - & $49.148^{* * *}$ & $23.376^{* * *}$ & $32.976^{* * *}$ & $43.289^{* * *}$ & $30.642^{* * *}$ & $43.368^{* * *}$ \\
\hline
\end{tabular}

Note: GLM parameterization - distribution family = binomial; link function = logit 

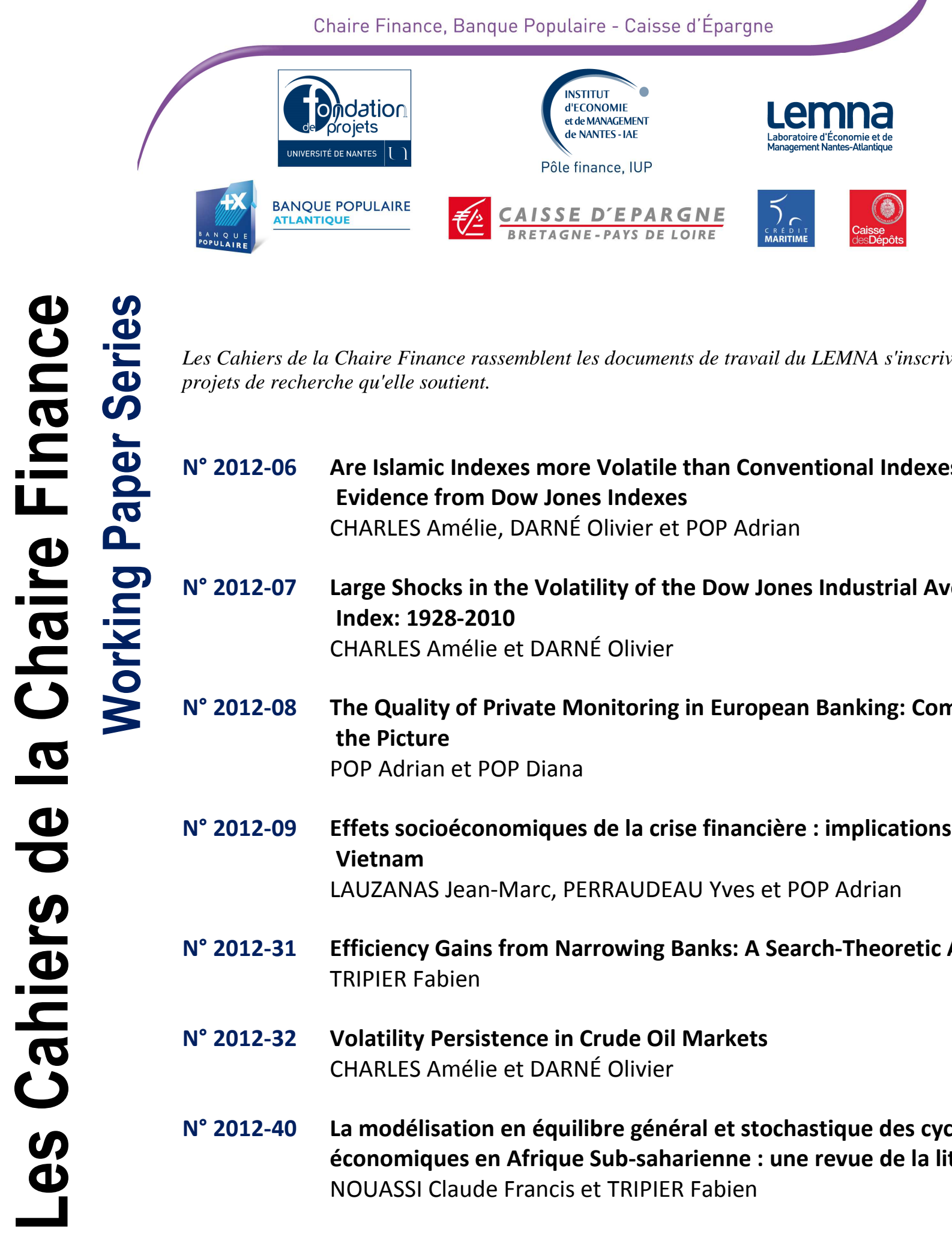

Les Cahiers de la Chaire Finance rassemblent les documents de travail du LEMNA s'inscrivant dans des projets de recherche qu'elle soutient.
$\mathbf{N}^{\circ}$ 2012-06 Are Islamic Indexes more Volatile than Conventional Indexes? Evidence from Dow Jones Indexes
CHARLES Amélie, DARNÉ Olivier et POP Adrian
$N^{\circ}$ 2012-07 Large Shocks in the Volatility of the Dow Jones Industrial Average Index: 1928-2010
CHARLES Amélie et DARNÉ Olivier
$\mathbf{N}^{\circ}$ 2012-08 The Quality of Private Monitoring in European Banking: Completing the Picture
POP Adrian et POP Diana
$\mathbf{N}^{\circ}$ 2012-09 Effets socioéconomiques de la crise financière : implications pour le Vietnam
LAUZANAS Jean-Marc, PERRAUDEAU Yves et POP Adrian
N² 2012-31 Efficiency Gains from Narrowing Banks: A Search-Theoretic Approach TRIPIER Fabien
$\mathbf{N}^{\circ}$ 2012-32 Volatility Persistence in Crude Oil Markets CHARLES Amélie et DARNÉ Olivier

$N^{\circ}$ 2012-40 La modélisation en équilibre général et stochastique des cycles économiques en Afrique Sub-saharienne : une revue de la littérature NOUASSI Claude Francis et TRIPIER Fabien

Les opinions exposées dans ce document n'engagent que les auteurs. Ceux-ci assument la responsabilité de toute erreur ou omission.

La Chaire Finance est une initiative de la Banque Populaire Atlantique, la Caisse d'Epargne Bretagne-Pays de Loire, la Caisse des Dépôts, du Crédit Maritime et de l'Université de Nantes, sous l'égide de la Fondation de Projets de I'Université de Nantes.

Site web : http://www.univ-nantes.fr/fondation/chairefinance

\section{Contact}

Chaire Finance, Banque Populaire - Caisse d'Epargne

IEMN-IAE, Chemin de Censive du Tertre - BP 52231

44322 Nantes cedex 3

Tél : +33 (0)2 40141660

Fax : +33(0)2 40141650

Email : Flavie.Chamard-Gueret@univ-nantes.fr 

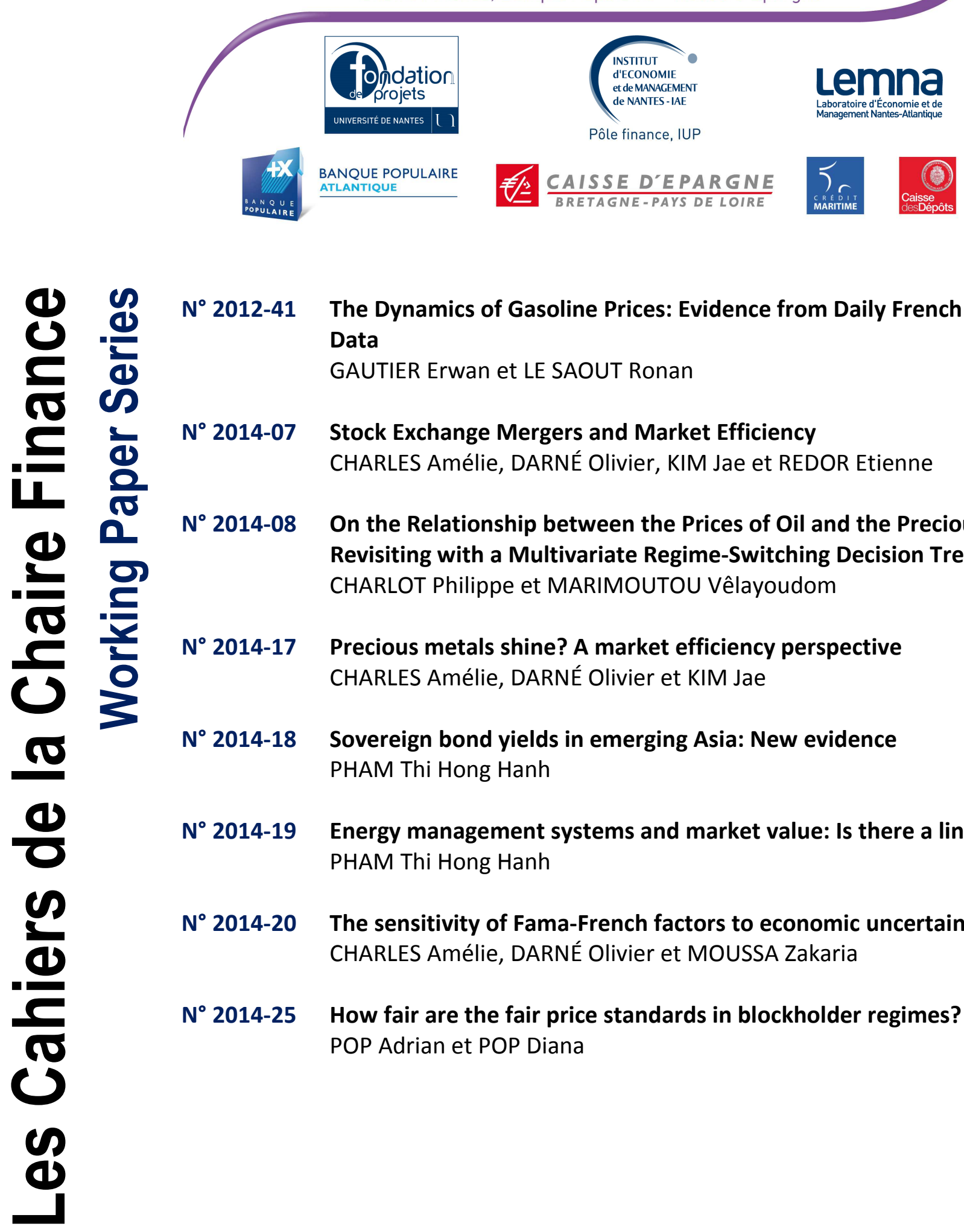

N²012-41 The Dynamics of Gasoline Prices: Evidence from Daily French Micro Data

GAUTIER Erwan et LE SAOUT Ronan

$N^{\circ}$ 2014-07 Stock Exchange Mergers and Market Efficiency

CHARLES Amélie, DARNÉ Olivier, KIM Jae et REDOR Etienne

$\mathbf{N}^{\circ}$ 2014-08 On the Relationship between the Prices of Oil and the Precious Metals:

Revisiting with a Multivariate Regime-Switching Decision Tree

CHARLOT Philippe et MARIMOUTOU Vêlayoudom

$N^{\circ}$ 2014-17 Precious metals shine? A market efficiency perspective CHARLES Amélie, DARNÉ Olivier et KIM Jae

$\mathbf{N}^{\circ}$ 2014-18 Sovereign bond yields in emerging Asia: New evidence PHAM Thi Hong Hanh

$N^{\circ}$ 2014-19 Energy management systems and market value: Is there a link? PHAM Thi Hong Hanh

$\mathrm{N}^{\circ}$ 2014-20 The sensitivity of Fama-French factors to economic uncertainty CHARLES Amélie, DARNÉ Olivier et MOUSSA Zakaria

$N^{\circ}$ 2014-25 How fair are the fair price standards in blockholder regimes?

POP Adrian et POP Diana 